\title{
Schadebegroting en tijdsverloop
}

\section{Over schade als veranderlijk verschijnsel, en wat dit betekent voor het schadevergoedingsrecht}

Marnix Hebly en Siewert Lindenbergh ${ }^{*}$

\section{Inleiding: schade als 'moving target'}

I. Lijdt een eigenaar schade wanneer zijn zaak als gevolg van onrechtmatig handelen door een ander een lagere verkoopwaarde vertegenwoordigt, maar wanneer deze zaak nog niet wordt verkocht? Bestaat er nog (toekomstige) schade wegens verlies van verdienvermogen vanaf het moment dat een verkeersslachtoffer in de periode tussen verkeersongeval en het moment van schadevaststelling onverwacht komt te overlijden door een hartinfarct? Welke rol speelt het 'ondernemingsrisico' bij de begroting van schade als gevolg van een periode van winstderving? Wanneer voor schade die verspreid over een periode wordt geleden een vergoeding wordt uitgekeerd in een som ineens, van welk te verwachten rendement moet dan worden uitgegaan?

2. Deze schadevergoedingsrechtelijke vragen hebben met elkaar gemeen dat zij samenhangen met het probleem van tijdsverloop: het antwoord op de vraag hoe groot de geleden schade is, hangt af van het bepalende begrotingsmoment en van de feitelijke uitgangspunten die aan de begroting ten grondslag worden gelegd. Om die feitelijke uitgangspunten te bepalen, moet men het verschil bepalen tussen enerzijds de situatie waarin de benadeelde zich na de aansprakelijkheidscheppende gebeurtenis bevindt, en anderzijds de situatie waarin hij zich zou hebben bevonden zonder deze gebeurtenis. Die vaststelling geschiedt in beginsel concreet: men houdt zo veel mogelijk rekening met de daadwerkelijke omstandigheden waarin de benadeelde in casu zich bevindt en waarin deze zich zou hebben bevonden indien de gebeurtenis waarop de aansprakelijkheid berust niet had plaatsgevonden.

3. Enerzijds gaat het bij de schadevaststelling telkens om een vergelijking met een hypothetische of fictieve situatie - de situatie zonder aansprakelijkheidscheppende gebeurtenis is vanaf die gebeurtenis immers per definitie niet-werkelijk - die zich dus ook moeilijk als een 'feitelijkheid' laat kennen. Men komt doorgaans ook niet verder dan een vermoeden van hoe die situatie zou zijn geweest. Partijen kunnen op dat scenario dan ook geen invloed uitoefenen; met het verstrijken van tijd kan wel meer 'virtuele zekerheid' worden verkregen omtrent de hypothetische situatie

* Mr. M.R. (Marnix) Hebly is als promovendus verbonden aan de Erasmus School of Law, Erasmus Universiteit Rotterdam. Prof. mr. S.D. (Siewert) Lindenbergh is als hoogleraar privaatrecht verbonden aan diezelfde faculteit. De auteurs danken Arnoud Pijls voor zijn waardevolle commentaar op een eerdere versie van dit preadvies. 
zonder de gebeurtenis waarop de aansprakelijkheid berust. Anderzijds vergelijkt men die hypothetische situatie met de situatie zoals die in werkelijkheid is (of nog zal zijn) na de aansprakelijkheidscheppende gebeurtenis. Ook over de positie waarin de benadeelde daadwerkelijk verkeert na de schadetoebrengende gebeurtenis wordt doorgaans na het verstrijken van enige tijd meer duidelijk.

4. Na verloop van tijd kan men dus steeds (iets) meer zeggen zowel over het scenario zonder de aansprakelijkheidscheppende gebeurtenis als over de situatie waarin de benadeelde is terechtgekomen, en gaandeweg wordt duidelijk of aanvankelijk heersende verwachtingen ook bewaarheid worden. De bij de schadevaststelling met elkaar te vergelijken posities kunnen in zoverre in de tijd gezien als 'moving targets' worden aangemerkt. ${ }^{\mathrm{T}}$

Bloembergen merkt in dit verband op: 'Alleen in zeer eenvoudige schadegevallen is de feitelijke ontwikkeling op het tijdstip van de onrechtmatige daad afgesloten: als een zaak vernietigd wordt, kan met die vernietiging de schade gegeven zijn, tenminste, als het missen van die zaak geen schadepost oplevert. Doorgaans is de werkelijkheid gecompliceerder en doen zich tot het tijdstip van de uitspraak allerlei feiten en omstandigheden voor, die van invloed zijn op de schade en de omvang daarvan.'2

5. Niet alleen doen zich tussen de aansprakelijkheidscheppende gebeurtenis en het tijdstip van de uitspraak - het tijdvak dat wij in het vervolg ook wel zullen aanduiden als de 'interim-periode' - allerlei feiten en omstandigheden voor die van invloed zijn op de schade en de omvang daarvan, maar er kan ten tijde van het oordeel over de schadeomvang ook (nog) sprake zijn van toekomstige schade, oftewel de op dat moment nog niet ingetreden, maar wel te verwachten schade. Toekomstige schade kan door de rechter bij voorbaat worden begroot, waarbij de schuldenaar kan worden veroordeeld tot betaling van een bedrag ineens of periodiek uit te keren bedragen (artikel 6:I05 BW). ${ }^{3}$ Wat daarbij als reeds geleden en als nog te lijden moet worden gezien, zal steeds afhangen van het als uitgangspunt genomen tijdsmoment. ${ }^{4}$

6. Wij kiezen voor dit preadvies als invalshoek dat schade een veranderlijk verschijnsel is in die zin, dat het bij de begroting van schade niet zozeer gaat om het bepalen van een statisch en absoluut gegeven, maar dat de uitkomst ervan (mede) afhangt van de vraag welk tijdsmoment - en welk perspectief - voor de schadevaststelling en schadebegroting beslissend is. Wij gebruiken deze invalshoek om een aantal 'figuren' uit het schadevergoedingsrecht te analyseren en om te verkennen op welke wijze het verstrijken van tijd als zodanig het schade(vergoedings)debat beïnvloedt.

I Vgl. S.D. Lindenbergh, 'Vaststelling van schade en de rol van de deskundige daarbij', in: G.G. Hesen, S.D. Lindenbergh \& G.E. van Maanen (red.), Schadevaststelling en de rol van de deskundige, Deventer: Kluwer 2008, p. 5 .

2 A.R. Bloembergen, Schadevergoeding bij onrechtmatige daad, Deventer: Kluwer I965, nr. 97.

3 Hetwetsartikel biedt de rechter daarnaast de bevoegdheid om de begroting van nog niet ingetreden schade geheel of gedeeltelijk uit te stellen.

4 Men spreekt hier ook wel van 'intreden' of 'verschijnen' van schade. 
7. Omdat het per definitie een rechtsstelsel overstijgende kwestie betreft, leent zij zich bij uitstek voor rechtsvergelijking. Het onderhavige preadvies is tot het $\mathrm{Ne}$ derlandse recht beperkt. Ten behoeve van de vergelijkbaarheid met het Belgische recht worden hierna eerst enkele uitgangspunten van het Nederlandse schadevergoedingsrecht voor het voetlicht gebracht (paragraaf 2). Daaropvolgend wordt het analytische onderscheid tussen ex ante- en ex post-perspectieven op schade uitgewerkt (paragraaf 3), aan de hand waarvan een aantal voorkomende 'figuren' binnen het schadevergoedingsrecht worden belicht: de zogenoemde 'abstracties' bij schadevaststelling (paragraaf 4 ), de begroting van voortdurende en toekomstige schade (paragraaf 5), de schadeloosstelling wegens onteigening (paragraaf 6) en de begroting van immateriële schade (paragraaf 7). Vervolgens zal aandacht worden besteed aan de toerekening van opkomend voordeel (paragraaf 8) en aan schade in de vorm van kosten (paragraaf 9 ). Wij ronden af met enkele algemene slotopmerkingen.

\section{Uitgangspunten van het Nederlandse schadevergoedingsrecht}

\section{I 'Nadeel dat voor iemand uit een bepaalde gebeurtenis voortvloeit'}

8. Schade wordt naar algemeen spraakgebruik wel gedefinieerd als het nadeel dat voor iemand uit een bepaalde gebeurtenis voortvloeit, of als al wat de gaafheid van iets tenietdoet. ${ }^{5}$ De wet bouwt voort op de eerstgenoemde betekenis. De aanwezigheid van schade veronderstelt een door een bepaalde gebeurtenis veroorzaakte verandering in een object die als een vermindering gewaardeerd wordt (een ongunstig verschil). In Nederland heeft in het bijzonder Bloembergen de in het schadebegrip besloten liggende elementen uitgewerkt. Hij onderscheidt daarbinnen een causaal element (het begrip schade heeft altijd betrekking op het gevolg van een bepaalde gebeurtenis), een vergelijkingselement (een vermindering veronderstelt altijd een vergelijking tussen het meerdere en het mindere) en een hypothetisch element (er wordt een vergelijking gemaakt met de situatie zoals die zou zijn geweest zonder de aansprakelijkheidscheppende gebeurtenis). ${ }^{6}$

9. De vraag wat schade nu eigenlijk is, wordt voor juristen in die zin telkens concreet, dat het debat zich voor hen doorgaans toespitst op de vraag naar het bestaan, de inhoud en de omvang van een verbintenis tot vergoeding van schade, ten aanzien waarvan in afdeling 6.I.Io van het Burgerlijk Wetboek de algemene bepalingen worden gegeven. De bepalingen zien in beginsel op alle civielrechtelijke verplichtingen tot schadevergoeding: niet alleen die wegens wanprestatie (artikel 6:74 e.v. BW) of onrechtmatige daad (artikel 6:I62 BW), maar ook wegens kwalitatieve aansprakelijkheden (artikel 6:I69 e.v. BW), zaakwaarneming (artikel 6:I98 BW) en ongerechtvaardigde verrijking (artikel 6:2I2 BW). De grondslag voor deze verbintenis treft men evenwel niet in deze afdeling aan, en dus ook niet het juridische kader waarvan het begrip schade afhankelijk is. Voor de invulling van het begrip schade moet steeds worden bezien wat de grondslag is waarop de

5 Aldus het Van Dale Groot woordenboek van de Nederlandse taal.

6 A.R. Bloembergen, Schadevergoeding bij onrechtmatige daad, Deventer: Kluwer I965, nrs. 8-24. 
aansprakelijkheid berust: die grondslag en de door partijen in concreto te dien aanzien ingenomen stellingen bepalen immers het perspectief dat bij de vaststelling van de schade tot uitgangspunt moet worden genomen. Zo dient men in geval van een onrechtmatige daad uit te gaan van een vergelijking van de situatie waarin de benadeelde als gevolg van de onrechtmatige daad verkeert, met de situatie waarin hij zonder de onrechtmatige daad zou hebben verkeerd, terwijl bij niet-nakoming van een verbintenis de schade wordt bepaald op basis van een vergelijking met de situatie bij behoorlijke nakoming. ${ }^{8}$

\subsection{Vermogensschade en ander nadeel}

Io. De wet bepaalt in artikel 6:95 BW dat schade die op grond van een wettelijke verplichting tot schadevergoeding moet worden vergoed, bestaat in vermogensschade en ander nadeel, dit laatste voor zover de wet op vergoeding hiervan recht geeft. ${ }^{9}$ Met dit onderscheid - dat overigens in vrijwel alle Europese rechtsstelsels te herkennen is - krijgt het begrip 'schade' binnen juridische kaders een tweesporig karakter. ${ }^{10}$ Het begrip 'vermogensschade' is als zodanig niet door de Nederlandse wetgever gedefinieerd; in de literatuur wordt het wel omschreven als schade die in het vermogen wordt geleden, schade die het vermogen 'raakt' en als schade die in geld is uit te drukken. ${ }^{\mathrm{II}}$ Vermogen kan hier het beste worden begrepen in financieel-economische zin en niet slechts in strikt juridische zin. ${ }^{12}$ Geld is dan de gebruikelijke rekeneenheid waarmee de waarde van een vermogen tot uitdrukking kan worden gebracht, en waarmee dus ook de waardevermindering die aan een bepaalde gebeurtenis wordt toegeschreven kan worden uitgedrukt. Geld dient ook als middel waarmee men de vermogensvermindering opheft: schadevergoeding wordt in beginsel voldaan in geld (artikel 6:103 BW).

II. Doorgaans wordt de omvang van het nadeel dat in vermogensschade bestaat 'gesplitst' in verschillende schadeposten. Zo bepaalt artikel 6:96 lid I BW dat onder vermogensschade zowel geleden verlies als gederfde winst wordt verstaan, waarmee wordt verduidelijkt dat niet alleen een vermogensvermindering als gevolg van de gebeurtenis waarop de aansprakelijkheid berust moet worden vergoed (damnum emergens), maar ook de vermogensstijging die de benadeelde als gevolg daarvan ontgaat, oftewel het uitblijven van een vermeerdering (lucrum cessans). ${ }^{13}$

$7 \quad$ Vgl. S.D. Lindenbergh, 'Over wat schade is... en waarom het bij de vaststelling daarvan in de praktijk zo dikwijls mis gaat', WPNR 2010/6867, p. 904-906.

8 Aldus HR I8 januari 2002, NJ 2002/I68 (Interplant/Oldenburger) en HR 26 april 2002, NJ 2004/2IO m.nt. Jac. Hijma (Sparrow en Heemskerk/Van Beukering-Louwers).

9 Men zou dit als de 'objecten' kunnen zien waarin een vermindering is ontstaan.

Io Lindenbergh, Schadevergoeding: algemeen, deel 1 (Mon. BW nr. B34) 20I4/40.

II Men spreekt hier ook wel van stoffelijke, materiële, geldelijke, op geld waardeerbare schade. Zie Asser/Hartkamp \& Sieburgh 6-II 2013/139 en Lindenbergh, in: GS Schadevergoeding, art. 6:95 BW, aant. A (online, laatst bijgewerkt I3 augustus 2015).

I2 Onder vermogen in juridische zin wordt wel verstaan het geheel van rechten en plichten dat op een bepaald moment aan iemand toekomt en dat op geld waardeerbaar is.

I3 Dit in overeenstemming met een 'eeuwenoude traditie'. Vgl. H.C.F. Schoordijk, Het algemeen gedeelte van het verbintenissenrecht naar het Nieuw Burgerlijk Wetboek, Deventer: Kluwer I979, p. 23 I. Vroeger maakte de wet deze onderscheiding met de woorden 'kosten, schaden en interessen', waarbij 'kosten' en 'schaden' op het geleden verlies zagen en 'interessen' op de derving van winst. 
In het tweede lid van artikel 6:96 BW, dat een niet-limitatieve opsomming bevat, wordt buiten twijfel gesteld dat de redelijke kosten van schadebeperking, schadevoorkoming en schadevaststelling en de kosten ter verkrijging van voldoening buiten rechte als vermogensschade worden aangemerkt. Het begroten van schade via afzonderlijke deelposten helpt niet alleen om het verschil tussen het vermogen met en het vermogen zonder de aansprakelijkheidscheppende gebeurtenis 'in te kleuren', maar het biedt ook ruimte om per post te bepalen of deze voor vergoeding in aanmerking komt, en zo ja, hoe deze moet worden begroot (artikel 6:97 BW). Ook hier speelt het verloop van tijd een rol, zij het meer 'zaakoverstijgend': schade die vroeger niet als zodanig werd (h)erkend, komt thans voor vergoeding in aanmerking. ${ }^{\mathrm{I}}$

I2. Wat onder 'ander nadeel dan vermogensschade' moet worden verstaan, hangt vanwege de negatieve omschrijving samen met de zojuist besproken invulling van het begrip vermogensschade. Dit 'andere nadeel' wordt doorgaans ook aangeduid als niet-vermogensschade of als immateriële schade (en wordt ook wel als afzonderlijke 'schadepost' aangemerkt). ${ }^{15}$ Met de term 'smartengeld' doelt men op de vergoeding ervan. In theorie zou het 'andere nadeel' ieder nadeel kunnen omvatten dat niet door de term 'vermogensschade' wordt bestreken, zij het dat het 'andere nadeel' slechts in beperkte gevallen voor vergoeding in aanmerking komt (artikel 6:95 BW) en dit begrip daarmee dus alsnog een zekere afbakening kent. De belangrijkste bepaling in dit kader is artikel 6:106 BW - dat een overigens aan het Duitse recht ontleend stelsel behelst - waarin een limitatieve opsomming wordt gegeven van gevallen waarin niet-vermogensschade wordt vergoed. ${ }^{16}$ De belangrijkste categorie betreft de immateriële schade wegens letsel (persoonsaantasting).

\subsection{Het beginsel van volledige vergoeding en concrete schadevaststelling}

I3. Als het hoofddoel van het schadevergoedingsrecht wordt aangemerkt het zo veel mogelijk bewerkstelligen van de (vermogens)toestand zoals die zou zijn geweest indien de schadetoebrengende gebeurtenis niet had plaatsgevonden. Die toestand zal het beste worden benaderd wanneer schade volledig wordt vergoed. ${ }^{17}$ Deze gedachte ligt dan ook als beginsel aan het schadevergoedingsrecht ten grondslag, zij het dat dit niet met zoveel woorden in afdeling 6.I.Io BW - een afdeling die uitblinkt in beknoptheid - is vastgelegd. Feitelijk herstel is hier het vertrekpunt, mits

I4 Lindenbergh spreekt in dit verband van de 'emancipatie van schadeposten'. Zie bijv. Lindenbergh, Schadevergoeding: algemeen, deel 1 (Mon. BW nr. B34) 2014/32 en S.D. Lindenbergh, 'Verzorging en huishoudelijke hulp, onzichtbare schade op een lastig kruisvlak', TVP 2006-4, p. IIo.

I5 Ook wordt wel gesproken van niet-economische, ideële, onstoffelijke, morele, extrapatrimoniale, niet op geld waardeerbare of niet-economische schade. Zie Asser/Hartkamp \& Sieburgh 6-II 2013/I39 en Lindenbergh, in: GS Schadevergoeding, art. 6:95 BW, aant. 4.I (online, laatst bijgewerkt I3 augustus 2015).

I6 Als algemene bepaling is de opsomming in art. 6:106 BW limitatief, maar dit staat er niet aan in de weg dat de wet in andere, bijzondere gevallen een recht op smartengeld toekent. Zie bijv. art. 7:510 BW in het kader van de reisovereenkomst, art. 89 Wetboek van Strafvordering (onterechte voorlopige hechtenis) en art. Io6 Vreemdelingenwet (opheffing vrijheidsontneming of -beperking).

I7 Lindenbergh, Schadevergoeding: algemeen, deel 1 (Mon. BW nr. B34) 20I4/Io. 
sprake is van redelijkerwijs herstelbare schade. Doorgaans wordt hieraan binnen het schadevergoedingsrecht evenwel uitwerking gegeven over de band van het vermogen: het moeten treffen van feitelijke herstelmaatregelen kan leiden tot een vergoedbare vermogensvermindering. ${ }^{18}$ Schadevergoeding in geld is door de wetgever ook bewust vooropgesteld, omdat dit vanuit praktisch oogpunt doorgaans het meest aantrekkelijk lijkt. ${ }^{19}$ Dat neemt niet weg dat die geldelijke schadevergoeding zo veel mogelijk in de sleutel van feitelijk herstel moet worden geplaatst. ${ }^{20}$ Voor zover schade redelijkerwijs niet of niet meer herstelbaar is, wordt dit (resterende) nadeel - materieel of immaterieel - met schadevergoeding gecompenseerd.

I4. De vergelijking tussen de toestand zoals deze in werkelijkheid is en de toestand zoals die zou zijn geweest zonder de aansprakelijkheidscheppende gebeurtenis vormt het feitelijke uitgangspunt voor de begroting van de schade, oftewel de vertaalslag ervan in geldelijke termen. Men neemt daarbij de door het individu concreet geleden schade als uitgangspunt.

Zo overweegt de Hoge Raad in het arrest Rijnstate/Reuvers in algemene bewoordingen: 'Als uitgangspunt voor de berekening van de omvang van een wettelijke verplichting tot schadevergoeding dient dat de benadeelde zoveel mogelijk in de toestand moet worden gebracht waarin hij zou hebben verkeerd indien de schadeveroorzakende gebeurtenis zou zijn uitgebleven. Hieruit volgt dat zijn schade in beginsel moet worden berekend met inachtneming van alle omstandigheden van het concrete geval. ${ }^{21}$

In beginsel geldt dit zowel voor vermogensschade als voor ander nadeel dan vermogensschade, zij het dat men in het laatste geval te maken heeft met schade die zich per definitie moeilijk in geld laat uitdrukken en daarom naar billijkheid wordt vergoed. Dat vermogensschade telkens ziet op een vermindering in het vermogen van de benadeelde, betekent dat in beginsel dus ook geen aanspraak op vergoeding ervan bestaat waar diens vermogen niet daadwerkelijk is verminderd. Bovendien betekent het dat wanneer er wel sprake is van een vermogensvermindering, deze vermindering de maatstaf (en de 'bovengrens') vormt voor de omvang van de vergoedingsplicht van de aansprakelijke partij. Het antwoord op de vraag of het vermogen al dan niet daadwerkelijk is verminderd, hangt af van het perspectief dat tot uitgangspunt wordt genomen, van de peildatum, en van de andere uitgangspunten die aan de schadevaststelling ten grondslag liggen.

I8 De eerdergenoemde redelijke herstelkosten als bedoeld in art. 6:96 lid 2 sub a BW.

I9 TM, PG Boek 6, p. 362 .

20 Zie S.D. Lindenbergh, 'Herstel bij letsel. Over de juridische fundering van verplichtingen in herstel', in: G.R. de Groot e.a., Kritiek op recht - Liber Amoricum Gerrit van Maanen, Deventer: Kluwer 20I4, p. 239-252 en over de herstelfunctie van schadevergoeding uitvoerig G.R.J. de Groot, 'Grenzen aan de mogelijkheden van een abstracte schadeberekening?', VR I980, p. 52 en J.M. Barendrecht, 'Schadeberekening en herstel', WPNR I985/5764, p. 790. 


\subsection{Het tijdstip van de uitspraak als uitgangspunt voor de schadevaststelling}

I5. Beziet men de vaak aangehaalde Differenztheorie van Mommsen, dan komt men de volgende - haast klassiek geworden - algemene definitie van (vermogens-) schade tegen:

'Het verschil tussen de waarde van iemands vermogen op een zeker tijdsmoment en de waarde welke dit vermogen op dat zelfde moment zou hebben gehad zonder de tussenkomst van de gebeurtenis waardoor schade werd veroorzaakt. (...) Tegenwoordig wordt algemeen onderschreven dat het tijdstip van de uitspraak, oftewel het tijdstip waarop de berekening wordt gemaakt, daarvoor de basis vormt. ${ }^{22}$

Hoewel deze definitie aanhaakt bij het 'vermogen als geheel' en daarmee uiterst abstract is - onderstreept zij wel het belang van het te kiezen tijdsmoment bij de vergelijking tussen de (vermogens)situatie met en zonder schadeveroorzakende gebeurtenis. Men lijkt ook moeilijk onder de keuze voor een bepalend tijdsmoment uit te kunnen komen als het gaat om de voor de schadevaststelling aan te leggen vergelijkingsmaatstaf: men vergelijkt niet de situatie zoals die was vóór de schadeveroorzakende gebeurtenis met de situatie zoals die daarná is (dat zou strikt genomen 'herstel in de oude toestand' zijn) maar men vergelijkt de situatie zónder de schadeveroorzakende gebeurtenis met de situatie waarin deze wél heeft plaatsgevonden. Het gaat bij de schadevaststelling dus om een vergelijking tussen twee naar een gelijk tijdsmoment gemeten situaties.

I6. Ook in Nederland wordt wel algemeen aangenomen dat het tijdstip waarop de rechter uitspraak doet het voor de schadevaststelling beslissende tijdstip is. Dat betekent dat de rechter in beginsel ook rekening moeten houden met feiten en omstandigheden die zich na de gebeurtenis waarop de aansprakelijkheid berust, hebben voorgedaan. ${ }^{23}$

De principiële vraag of de rechter bij de schadebegroting ook rekening moet houden met in de loop van de procedure intredende wijzigingen in omstandigheden, lijkt als eerste aan de orde te komen in het arrest Liezen/Nijmeijer. ${ }^{24}$ Nijmeijer verloor haar echtgenoot door een verkeersongeval en vorderde op grond van artikel I406 Oud BW ver-

22 Vrij vertaald naar Mommsen: 'Die Differenz zwischen dem Betrage des Vermögens einer Person, wie derselbe in einem gegebenen Zeitpunkte ist, und dem Betrage, welchen dieses vermögen ohne die Daswischenkumst eines bestimmten beschädigenden Ereignisses in dem zur Frage stehenden Zeitpunkte haben würde (...) Heutzutage gilt jedoch allgemein die Regel, das die Zeit des Urtheils (...) die Zeit, zu welcher die Berechnung des Interesse vorgenommen wird, zu Grunde zu legen ist.' Zie F. Mommsen, Beiträge zum Obligationenrecht II, Zur Lehre von dem Interesse, Brunswijk I855, p. 3 .

23 Zie bijv. Langemeijer in zijn conclusie voor HR 3 februari I956, NJ I956/I59 m.nt. L.E.H. Rutten (Liezen/Nijmeijer), A.R. Bloembergen, Schadevergoeding bij onrechtmatige daad, Deventer: Kluwer I965, nr. 97, L.E.H. Rutten, 'Het recht op schadeloosstelling van de eigenaar van een auto welke als gevolg van een aanrijding een waardevermindering heeft ondergaan', VR I964-4, p. 79-80, A.J. Akkermans, 'De twee gezichten van inkomensschade bij letsel. Over ontstaansmoment, wettelijke rente en verjaring', in: C.J.M. Klaassen \& A.J. Akkermans, Het moment van ontstaan van schade, Lelystad I998, p. 62 en Lindenbergh, in: GS Schadevergoeding, art. 6:97 BW, aant. I9 (online, laatst bijgewerkt I3 augustus 2015).

24 HR 3 februari 1956, NJ 1956/158 m.nt. L.E.H. Rutten (Liezen/Nijmeijer). 
goeding van haar schade, bestaande uit derving verlies van levensonderhoud, voor de vaststelling waarvan onder meer de 'behoeftigheid' bepalend is. Gedurende de procedure, en ruim drie jaar na het ongeval, overleed haar vader en werd zij deelgerechtigde in diens nalatenschap. De vraag rees of bij de vaststelling van de (overlijdens)schade van de weduwe rekening moet worden gehouden met de aan haar tijdens het geding toegevallen nalatenschap. ${ }^{25}$ Dit is inderdaad het geval: de rechter moet ook rekening houden met de verandering in de financiële draagkracht wanneer die verandering opkomt op een tijdstip gelegen na de onrechtmatige daad en na het overlijden van het slachtoffer.

Volgens Langemeijer doet dit recht aan het eigen karakter van artikel I406 Oud BW, waarin het gaat om een afweging van de belangen van partijen (draagkracht enerzijds en behoefte anderzijds): 'Ik zou nu menen, dat zulk een regeling beter zijn doel bereikt, wanneer de rechter tot aan zijn uiteindelijke beslissing rekening kan houden met de omstandigheden, zoals zij dan zijn, dan wanneer hij gedwongen zou zijn zich te richten naar de toestand van het ogenblik van het ongeval en daardoor mogelijkerwijze tevens gedwongen zou zijn een beslissing te geven, die ten tijde dat zij wordt gegeven aan de belangen van partijen in het minst geen recht meer doet wedervaren. ${ }^{26}$

Bloembergen vindt de rechtvaardiging hiervoor in het beginsel van volledige schadevergoeding: 'Vloeit dit trouwens niet voort uit de regel der volledige schadevergoeding? De werkelijk geleden schade wordt immers niet vergoed, als de ontwikkeling van het schadegeval niet in haar geheel in aanmerking genomen wordt. ${ }^{27}$ Bloembergen wijst er overigens nog op dat men deze uitspraak niet te snel moet veralgemeniseren, gezien het feit dat het hier om toepassing van de bijzondere regeling van artikel I406 Oud BW ging, maar wijst er tegelijkertijd op dat de rechter ook buiten schadevergoedingskwesties steeds het tijdstip van beoordeling tot uitgangspunt moet nemen, zoals bij de beoordeling van het vereiste van benadeling bij een beroep op de Pauliana. ${ }^{28}$ Bovendien is de eiser steeds bevoegd om binnen de grenzen van de eisen van een goede procesorde zijn eis te verminderen, veranderen of vermeerderen zolang de rechter nog geen eindvonnis heeft gewezen (artikel I29-I30 Rv).

De hierna nog te bespreken schadevergoedingsrechtelijke figuren laten evenwel zien dat, hoe en waarom soms van dit uitgangspunt wordt afgeweken.

\section{Ex ante- versus ex post-perspectieven op schade}

\section{I Inleiding}

I7. Men kan moeilijk algemene uitspraken doen over het moment waarop schade wordt vastgesteld, anders dan dat dat moment lijkt af te hangen van allerlei omstandigheden die zowel betrekking hebben op de schade en de aansprakelijkheidscheppende gebeurtenis als op de wijze waarop de schadeafwikkeling verloopt.

25 Van voordeelstoerekening kon hier immers geen sprake zijn, nu het overlijden van de vader van Nijmeijer niet het gevolg was van de onrechtmatige daad.

26 Langemeijer in zijn conclusie voor $\mathrm{HR}_{3}$ februari 1956, NJ 1956/I59 m.nt. L.E.H. Rutten (Liezen/ Nijmeijer).

27 A.R. Bloembergen, Schadevergoeding bij onrechtmatige daad, Deventer: Kluwer I965, nr. 97.

28 HR 23 december 1949, NJ 1950/262 m.nt. Ph.A.N. Houwing (Boendermaker/Schopman). 
In veel gevallen zal het moment waarop de schade uiteindelijk wordt vastgesteld enigszins willekeurig bepaald zijn. Bijvoorbeeld in de situatie waarin sprake is van een onverwacht langdurige hoofdprocedure over aansprakelijkheid en waarin het lange tijd onzeker blijft of daarop een schadestaatprocedure zal volgen; het debat over de schadeomvang wordt dan in de tijd vooruitgeschoven naar een vooraf niet precies in te schatten moment. ${ }^{29}$ De schadevaststelling kan systematisch gezien ook moeilijk plaatsvinden zonder dat men eerst de aansprakelijkheidscheppende gebeurtenis precies voor ogen heeft, nu deze gebeurtenis steeds als het 'aanvangspunt' van de vergelijking te gelden heeft: aan de hand van de condicio sine qua non-test dient immers in eerste instantie te worden vastgesteld of een omstandigheid - vanuit een oogpunt van logica - mag worden aangemerkt als gevolg van de gebeurtenis waarop de aansprakelijkheid berust. ${ }^{30}$ De begroting van schade komt doorgaans pas aan de orde nadat is vastgesteld dat aan de voorwaarden voor aansprakelijkheid is voldaan..$^{3}$

I8. Sterk verweven met het moment waarop de schade wordt vastgesteld, en van groter belang voor het schadedebat, is het moment waarnaar de schade moet worden bepaald of, met andere woorden, het punt op de tijdlijn dat voor de schadevaststelling als uitgangspunt wordt genomen. Men duidt dit wel aan met de term 'peildatum', die in het algemeen refereert aan het gegeven dat men zich bij gegevens die afhankelijk zijn van tijd soms gedwongen ziet om het 'bepalende moment' aan te wijzen. Informatie is gerelateerd aan een tijdstip, en naarmate er in de tijd meer veranderingen zijn, neemt de relevantie van de peildatum toe. In de schadevergoedingsrechtelijke literatuur komt men de term 'peildatum' vooral tegen in de literatuur over de begroting van voortdurende en toekomstige schade (waarover paragraaf 5) maar ook bij 'momentschades', zoals de waardevermindering van een zaak, werkt men met een zekere 'peildatum' (zie paragraaf 4.2). Men zou natuurlijk kunnen stellen dat schade steeds moet worden gemeten naar het moment waarop deze wordt vastgesteld: in dat geval vallen het moment waarop en het moment waarnaar de schadeomvang wordt bepaald samen. De schade wordt dan vastgesteld op basis van alle informatie die beschikbaar is ten tijde van de schadevaststelling, ook de informatie die pas is opgekomen in de interim-periode. Later optredende gebeurtenissen en later opkomende informatie die van invloed zijn op de (inschatting van de) omvang van de schade worden dan dus meegenomen in de vergelijkingsanalyse tussen de situatie met en de situatie zonder aansprakelijkheidscheppende gebeurtenis.

19. In de literatuur bestaat evenwel discussie over de - principiële - vraag naar welk moment schade moet worden vastgesteld. Geïnspireerd door de (vooral Engelstalige) literatuur over de begroting van schade in de bedrijfssfeer - bestaande in derving van winst en vermindering van (bedrijfs)waarde - hanteren wij in

29 Zie uitvoerig T.F.E. Tjong Tjin Tai, 'De ambivalente regeling van de schadestaatprocedure', TCR 2008-I, p. I-7.

30 S.D. Lindenbergh, 'Vaststelling van schade en de rol van de deskundige daarbij', in: G.G. Hesen, S.D. Lindenbergh \& G.E. van Maanen (red.), Schadevaststelling en de rol van de deskundige, Deventer: Kluwer 2008, p. 6.

Waarbij het bestaan van schade als zodanig dus wel 'bestanddeel' is van die aansprakelijkheid. 
dit preadvies het onderscheid tussen ex ante- en ex post-benaderingen bij schade. ${ }^{32}$ Simpel gezegd houdt de ex ante-benadering in dat schade moet worden gemeten naar het tijdstip van ontstaan van de schade. De waardering van het nadeel en de daarmee samenhangende verwachtingen moeten dan naar dat moment worden bepaald. Of anders gezegd: de rechter gaat uit van wat men wist of kon weten op die peildatum. De ex post-benadering gaat daarentegen uit van de daadwerkelijke uitkomst van het schadeverloop voor zover (inmiddels) bekend ten tijde van het moment waarop de schade wordt vastgesteld. Bij het ex ante-perspectief zal er een verschil bestaan tussen het moment waarop de schade wordt vastgesteld en de peildatum, terwijl deze momenten bij de ex post-benadering samenvallen. Het moment van ontstaan van schade en het moment van de aansprakelijkheidscheppende gebeurtenis hoeven overigens bij een ex ante-benadering niet samen te vallen. Beide momenten laten zich soms lastig bepalen, en hier zijn allerlei nuanceringen denkbaar. Omwille van de eenvoud spreken wij bij het uitwerken van de ex antebenadering van het 'veroorzakings- of ontstaansmoment' van de schade.

\subsection{Het ex ante-perspectief}

20. Aan beide benaderingen kleven voor- en nadelen. Het ex ante-'verwachtingenperspectief' brengt als voordeel met zich dat het moment waarop de schade wordt vastgesteld - en dat dus enigszins willekeurig bepaald kan zijn - niet van invloed is op het resultaat van de schadevaststelling: die taxatie is nu eenmaal gefixeerd op het moment van de aansprakelijkheidscheppende gebeurtenis, of althans op de peildatum. Hiermee omzeilt men het gevaar dat waarde wordt toegevoegd of weggenomen als gevolg van de perfect hindsight. Daarmee wordt bedoeld dat men door invloed van ontwikkelingen tijdens de interim-periode een hogere of lagere waarde aan het schadeobject toekent dan op grond van de verwachtingen op het moment van de aansprakelijkheidscheppende gebeurtenis gerechtvaardigd zou zijn geweest. ${ }^{33}$ Iets abstracter geformuleerd: de economische waardering van een (schade)object wordt doorgaans gekenmerkt door verwachte toekomstige opbrengsten en de daarbij behorende risicokarakteristieken. ${ }^{34}$ Wanneer men schade ex ante bepaalt - dus 'gemeten' naar het moment van veroorzaken of ontstaan - dan moeten die risico's dus worden verdisconteerd in de waardering van het verlies, en 'abstraheert' men dus van daadwerkelijke gebeurtenissen en ontwikkelingen nadien. Worden risico's en onzekerheden die eigenlijk wel steeds waardebepalend zijn (achteraf) niet meegewogen, dan zou een vorm van 'over- of ondercom-

32 In dit verband valt onder meer te verwijzen naar K. Bonsack, 'Damages assessment, Janis Joplin's yearbook and the Pie-Powder Court', George Mason Law Review I990-I, p. I-26, T.J. Bowles, 'Hindsight in commercial damages analysis', Journal of Legal Economics 2008-3, p. I-I4, L. Zhiyong \& R. Avraham, 'Ex ante versus ex post expectation damages', International Review of Law and Economics 2012-4, p. 339-355, M.K. Dunbar, E.A. Evans \& R.L. Weil, 'Ex ante versus ex post damages calculations', in: R.L. Weil, D.G. Lentz \& D.P. Hoffman (red.), Litigation Services Handbook: The Role of the Financial Expert, John Wiley \& Sons 2012, hoofdstuk 5 (digitaal) en J.D. Taurman \& J.C. Bodington, 'Measuring damage to a firm's profitability: ex ante or ex post?', The Antitrust Bulletin I992, p. 57-I06. Zie in de Nederlandstalige literatuur J. Joling, 'De vaststelling van vermogensschade wegens gederfde winst of geleden verlies', NTBR 2007-Io, p. 46I-467.

33 Vgl. J. Joling, 'De vaststelling van vermogensschade wegens gederfde winst of geleden verlies', NTBR 2007-IO, p. 465.

34 Vgl. R. van Oeveren, 'Waarde op waarde geschat. Waarderingsmethoden met elkaar vergeleken', Finance \& Control 2007-6, p. 26-3I. 
pensatie' het gevolg zijn; beide zouden niet stroken met het beginsel van volledige vergoeding. Fisher en Romaine verwoorden dit in het kader van de begroting van gederfde winst aldus:

'Giving the plaintiff the lost profits that hindsight suggests does not place it in the position it would have occupied without the violation; it replaces an uncertain world with a particular outcome. 35

Een ex ante-benadering past bij uitstek bij begroting op een bedrag ineens ('lump sum') en verhoudt zich slechter tot periodieke schadevaststelling, nu dat laatste instrument juist bij uitstek ziet op aanpassingen aan later optredende gebeurtenissen of opkomende omstandigheden.

2I. Schadevaststelling ex ante brengt met zich dat de omvang van de schade gefixeerd is in die zin dat geen van de bij het schadedebat betrokken partijen profiteert of nadeel ondervindt van het tijdsverloop tussen aansprakelijkheidscheppende gebeurtenis en schadevaststelling, en er dus in dit opzicht van het systeem ook geen prikkels kunnen uitgaan tot het versnellen of het vertragen van het schadeafwikkelingsproces. In de rechtseconomische literatuur wordt daarom vaak voor een ex ante-benadering gepleit. De schade wordt min of meer 'vastgepind' aan (de waardering naar) het veroorzakings- of ontstaansmoment en daar valt geen invloed meer op uit te oefenen; de hoogte van de schadevergoeding is dan niet meer afhankelijk van de informatie die in de loop van de tijd bekend wordt (deze 'fluctueert' dus niet) en het schadevergoedingsdebat wordt minder door toeval beheerst. Hooguit kan er met het verloop van tijd nog wel informatie opkomen die iets zegt over de situatie zoals die per peildatum was. ${ }^{36}$ Een ex anteschadevaststelling laat overigens de mogelijkheid onverlet dat in het kader van de schadetoerekening ex artikel 6:98 BW wordt geoordeeld dat - óók vanwege later opkomende feiten en omstandigheden - het (ex ante vastgestelde) schadebedrag niet (volledig) aan de aansprakelijke kan worden toegerekend. Onafhankelijkheid van het momentwaarop de schade wordt vastgesteld kan bijdragen aan rechtszekerheid door finaliteit te bevorderen: de schade is in de tijd gezien niet langer een 'moving target'. Men kan dus zowel principiële als praktische argumenten hebben voor een ex ante-schadevaststelling.

\subsection{Het ex post-perspectief}

22. De benadering die hier lijnrecht tegenover staat, is de benadering ex post, waarin het schadeverloop wordt bepaald aan de hand van alle informatie die beschikbaar is ten tijde van de schadevaststelling, ongeacht de vraag of gebeurtenissen of ontwikkelingen wel voorzienbaar waren ten tijde van de aansprakelijkheidscheppende gebeurtenis. ${ }^{37}$ Het concrete schadeverloop laat zich dan met meer zeker-

35 F.M. Fisher \& R.C. Romaine, 'Janis Joplin's yearbook and the theory of damages', Journal of Accounting, Auditing \& Finance I990, p. I45-I57.

36 Zie voor een voorbeeld het in nr. 82 te bespreken arrest Onteigening Berkel en Rodenrijs.

37 Die voorzienbaarheid van de (omvang van de) schade kan ook dan nog wel van belang zijn in het kader van art. 6:98 $\mathrm{BW}$, maar het betreft daarbij de vraag naar redelijke toerekening en niet zozeer de vaststelling van schade. 
heid vaststellen: niet alleen heeft (een deel van) het verloop der gebeurtenissen na de aansprakelijkheidscheppende gebeurtenis inmiddels feitelijk plaatsgevonden, maar ook het verloop der dingen zonder die gebeurtenis kan met meer 'virtuele zekerheid' worden ingeschat. Uitgaande van het beginsel van volledige vergoeding en het uitgangspunt dat schade concreet wordt vastgesteld, lijkt schadevaststelling ex post daar - althans op het eerste gezicht - ook het beste bij aan te sluiten. Men gebruikt alle opgekomen informatie bewust om het daadwerkelijk geleden nadeel zo nauwkeurig mogelijk vast te stellen. Waarom zou men inzicht dat met het voortschrijden van de tijd is verkregen niet gebruiken? Wanneer men ten tijde van de schadevaststelling alle informatie gebruikt die men ter beschikking heeft, kan men immers met meer nauwkeurigheid bepalen welke schade de benadeelde uiteindelijk blijkt te lijden, wat het meest in overeenstemming zou zijn met het uitgangspunt van compensatoire schadevergoeding.

23. Het toepassen van een ex post-benadering brengt met zich dat, gaandeweg of achteraf gezien, de aanvankelijk verwachte schade kan 'wegebben' of juist in omvang toenemen en dat het moment waarop de schade wordt vastgesteld cruciaal is voor partijen, wat prikkels tot versnellen of vertragen van het schadeafwikkelingsproces met zich zou kunnen brengen.

\subsection{Hybride benaderingen}

24. Wanneer een mix van ex ante- en ex post-elementen wordt toegepast bij de begroting van schade, dan wordt wel gesproken van een 'hybride' benadering. Dat kan bijvoorbeeld door de omvang van de schade ex post vast te stellen op basis van het feitelijk verloop na de aansprakelijkheidscheppende gebeurtenis, en de schade vervolgens 'terug te rekenen' naar het veroorzakings- of ontstaansmoment aan de hand van een disconteringsvoet, die uitdrukking geeft aan de onzekerheid die er aanvankelijk mee gepaard ging. Dat lijkt enigszins paradoxaal: bij een dergelijke benadering wordt weliswaar gebruikgemaakt van alle ex post opgekomen informatie en optredende gebeurtenissen om de schade zo nauwkeurig mogelijk vast te stellen, maar de op grond daarvan bepaalde schade wordt 'teruggebracht' naar het veroorzakings- of ontstaansmoment aan de hand van een ex ante bepaalde factor, die uitdrukking geeft aan het risico dat de ontwikkelingen na dat moment afwijken van wat op dat moment kon worden verwacht. Of anders gezegd: men vervangt ex ante-verwachtingen (deels) door uitkomsten, maar berekent de contante waarde daarvan naar het veroorzakings- of ontstaansmoment alsof het nog steeds om een verwachting gaat, en gebruikt daarvoor dus de disconteringsvoet die uitdrukking zou geven aan de onzekerheid waarmee dat scenario gepaard zou zijn gegaan als het inderdaad nog een verwachting was. Op die manier wordt enigszins tegemoetgekomen aan het bezwaar tegen de ex post-benadering dat achteraf gezien (ondernemings)risico's buiten beschouwing worden gelaten die wel degelijk waardebepalend waren op het moment waarop de schade werd toegebracht, oftewel het bezwaar dat een onzekere wereld ten onrechte door een daadwerkelijke uitkomst zou worden 'vervangen'. 


\section{$3 \cdot 5 \quad$ Slot}

25. De begrippen ex ante en ex post vormen handzame begrippen om de betekenis van tijdsverloop voor de begroting van schade te verkennen. Waar ex ante ziet op de (aanvankelijk) heersende verwachtingen, is een ex post-benadering op uitkomsten gebaseerd. Het draait om de vraag welk moment men als peildatum hanteert. Een 'hybride' benadering relativeert de invloed van de peildatumkeuze, door elementen van de ex post-benadering (het gebruik van later opkomende informatie) te combineren met ex ante-elementen (aanvankelijke 'risicofactoren'). Deze begrippen zullen wij gebruiken om in het hiernavolgende een aantal verschillende schadevergoedingsrechtelijke figuren te analyseren. Eerder werd reeds opgemerkt (paragraaf 2.4) dat in Nederland wel algemeen wordt aangenomen dat het tijdstip waarop de rechter uitspraak doet het voor de schadevaststelling beslissende tijdstip is: uitgangspunt zou dus een ex post-benadering zijn. Of, en zo ja, hoe dit uitgangspunt in verschillende gevallen wordt gehanteerd, wordt in het navolgende nader bestudeerd.

\section{$4 \quad$ Tijdsfixatie, abstracties en waardering}

\section{I Abstracties bij de vaststelling van schade}

26. Ten aanzien van vermogensschade wordt wel onderscheid gemaakt tussen de concrete en abstracte wijze van schadevaststelling..$^{38}$ Waar concrete schadevaststelling inhoudt dat zo veel mogelijk rekening wordt gehouden met de bijzonderheden van het desbetreffende geval en met de subjectieve omstandigheden waarin de benadeelde zich bevindt, kan men zeggen dat het bij abstracte schadevaststelling meer gaat om de vraag hoe groot in het algemeen de te verwachten schade is van een schuldeiser die in een gelijksoortige positie verkeert als de eiser in het geding (en kunnen bepaalde omstandigheden daarom buiten beschouwing blijven). ${ }^{39}$ Overigens gaat het niet steeds om de vraag of 'de' schade concreet dan wel abstract moet worden begroot, maar om de vraag of bij de vaststelling van de schade in een concrete situatie ten aanzien van een specifieke schadepost van een bepaalde omstandigheid mag worden geabstraheerd. Het gaat dus doorgaans om de vraag welke factoren bij de vaststelling van schade al dan niet in ogenschouw moeten worden genomen..$^{\circ}$ De vraag in welke gevallen en op welke wijze abstrahering op haar plaats is, is aan de rechter overgelaten, hoewel op sommige plaatsen de wet uitdrukkelijk in een (keuze voor een) abstracte benadering voorziet. ${ }^{4}$ Van belang is verder dat het resultaat van de abstracte wijze van schadevaststelling als

$3^{8}$ Men duidt dit onderscheid ook wel met de termen subjectieve en objectieve wijze van schadevaststelling. Discussie over dit thema treft men overigens in ieder rechtsstelsel. Vgl. E. Hondius, 'Schadevergoeding: recht in ontwikkeling (afd. 6.I.Io en II BW)', in: E. Hondius (red.), Vijfjaar nieuw vermogensrecht, Deventer: Kluwer I998, p. 88.

39 Asser/Hartkamp \& Sieburgh 6-II 2013/35 en Klaassen, Schadevergoeding: algemeen, deel 2 (Mon. BW nr. B35) 2007/I0.

40 S.D. Lindenbergh, 'Abstracties bij vaststelling van schade', in: C.J.M. Klaassen \& J. Spier (red.), Abstracte schadeberekening, Deventer: Kluwer 20I3, p. 22 e.v. Zie ook A.R. Bloembergen, Schadevergoeding bij onrechtmatige daad, Deventer: Kluwer I965, nr. 26. MvA II, PG Boek 6, p. 339. 
een minimumbedrag wordt gezien: indien de concrete schade hoger blijkt dan de abstract berekende, kan ook vergoeding van die 'extra schade' worden verkregen (een 'concretisering naar boven' is dus - binnen grenzen - mogelijk). ${ }^{2}$

\subsection{Waardevermindering van roerende zaken}

27. Bij zaaksbeschadiging, ${ }^{43}$ zoals schade aan een auto, is uitgangspunt dat de eigenaar een nadeel in zijn vermogen lijdt dat gelijk is aan de waardevermindering van de zaak vóór en onafhankelijk van enig herstel.

Onder meer in het arrest A. en N.|Hiddema bevestigt de Hoge Raad het in zijn eerdere rechtspraak tot stand gekomen toetsingskader voor de begroting van schade aan een zaak. ${ }^{44}$ In dat arrest stelt de Hoge Raad voorop '(...) dat de eigenaar van een zaak die wordt beschadigd, door die beschadiging reeds voor en onafhankelijk van herstel daarvan in zijn vermogen een nadeel lijdt, gelijk aan de waardevermindering welke het desbetreffende vermogensbestanddeel heeft ondergaan, en dat, indien het een zaak betreft waarvan herstel mogelijk en verantwoord is, het geldsbedrag waarin deze waardevermindering kan worden uitgedrukt, in het algemeen gelijk zal zijn aan de - naar objectieve maatstaven berekende - kosten, welke met het herstel zullen zijn gemoeid.45

28. Bij zaaksbeschadiging bestaat dus aanspraak op vergoeding van de waardevermindering die reeds voor en onafhankelijk van herstel wordt geleden, oftewel: ongeacht de vraag of de benadeelde na de beschadiging daadwerkelijk tot herstel over is gegaan of nog over wil gaan. Van die omstandigheid wordt dus geabstraheerd. Een nadere abstrahering vindt plaats doordat deze waardevermindering in het algemeen kan worden uitgedrukt - van een 'moeten' wordt hier niet gesproken - in de naar objectieve maatstaven berekende herstelkosten, althans indien het een zaak betreft waarvan herstel mogelijk en verantwoord is..$^{46}$ Men abstraheert dan dus ook van de omvang van de herstelkosten, ingeval deze daadwerkelijk na de beschadiging zouden zijn gemaakt (deze kunnen immers om allerlei redenen hoger of lager zijn dan de naar objectieve maatstaven berekende herstelkosten). Men beoordeelt de schade dan dus vanuit een ex ante-perspectief, oftewel naar de meer objectieve verwachting die heerste ten tijde van de beschadiging. Als er later daadwerkelijk is hersteld tegen hogere kosten, dan kan de benadeelde - binnen de grenzen van de redelijkheid - kiezen voor een concrete wijze van schadevaststelling (ex post). ${ }^{47}$

42 Zie onder meer Asser/Hartkamp \& Sieburgh 6-II* 2009/35-40, Asser/Hijma 7-I* 20I3/480 en H.B. Krans, Schadevergoeding bij wanprestatie, Deventer: Kluwer I999, p. 7I e.v.

43 Onder zaakbeschadiging wordt verstaan de 'aantasting van de substantie van een zaak'. Zie uitvoerig Salomons, in Schadevergoeding: zaakschade (Mon. BW nr. B38) I993/I9.

44 De Hoge Raad koos reeds principieel voor abstractie bij schadevaststelling in HR I6 juni I96I, NJ I96r/444 m.nt. L.E.H. Rutten (PTT-telefoonkabels).

45 HR 7 mei 2004, NJ 2005/76 m.nt. C.J.H. Brunner (A. en N./Hiddema), r.o. 3.6, onder verwijzing naar HR I6 juni I96I, NJ I96r/444 m.nt. Ph.A.N. Houwing (Staat/Knebel).

46 Of herstel nog mogelijk is, zal afhangen van de vraag of het nog feitelijk mogelijk is om de schade (deels) te doen wegnemen. Of herstel nog verantwoord is, pleegt te worden beoordeeld aan de hand van een economische maatstaf: is de waarde na herstel lager dan de waarde van de beschadigde zaak vermeerderd met de kosten van herstel, dan is herstel economisch niet verantwoord.

47 De keuzevrijheid die de benadeelde hier zou hebben, is geen onomstreden punt. Zie hierover Lindenbergh, Schadevergoeding: algemeen, deel 1 (Mon. BW nr. B34) 20I4/39. 
29. Deze 'dubbele abstractie' - van het maken van kosten en van de eventuele omvang daarvan - vloeit voort uit het uitgangspunt dat de waardevermindering waar het hier om gaat terstond intreedt op het moment waarop de zaak beschadigd raakt; wat daarna nog plaatsvindt, is in beginsel dus niet relevant..$^{4}$ Beslissend voor deze abstracte schadevaststelling is dus de waardevermindering 'gemeten' naar het tijdstip van de beschadiging. ${ }^{49}$ Het ligt daarom voor de hand om bij de abstracte schadevaststelling ook de herstelkosten ex ante te bepalen. Bloembergen verwoordt het aldus:

'Wat de tijd betreft is het niet twijfelachtig, dat het tijdstip van de beschadiging beslissend is. Naar dat tijdstip zullen derhalve de waardevermindering en de herstelkosten berekend moeten worden. Het is duidelijk, dat de benadeelde zelfs bij de grootste voortvarendheid niet op het tijdstip van de beschadiging zelf kan repareren; soms zal de schadebeperkingsplicht zelfs meebrengen, dat hij enige tijd met de reparatie moet wachten. Niettemin blijft voor de abstracte schadeberekening het tijdstip van de beschadiging beslissend. ${ }^{\circ}$

\section{Kritisch hierover is Deurvorst, waar zij wijst op het risico van 'overcompensatie':}

'Met enig wringen zijn deze regels met de wet te verenigen, wanneer men ervan uitgaat dat op het moment van beschadiging de objectieve herstelkosten als toekomstige schade zijn te beschouwen. Door de verplaatsing van de peildatum voor het bestaan van de vermogensschade naar het moment van de feitelijke beschadiging van de zaak - in plaats van naar de invloed op de vermogenstoestand - is de vraag of de toekomstige herstelkosten daadwerkelijk zijn besteed, niet meer relevant. Deze constructie neemt echter niet weg dat bij het stellen van onvoldoende eisen aan de zekerheid van het intreden van de toekomstige schade (...) het gevaar bestaat dat het uitgangspunt dat schadevergoeding dient ter compensatie van geleden of toekomstige schade (...) in het gedrang komt..5r

30. Door als peildatum het moment van de feitelijke beschadiging te hanteren voor het bestaan en de omvang van de vermogensschade, zijn latere ontwikkelingen inderdaad niet meer relevant. De vraag is of het hier wel om een toekomstschade gaat. Daarvoor zou dan pleiten dat de schadevergoeding als een soort vergoeding bij voorbaat kan worden gezien van de nog te maken herstelkosten. De redenering is echter dat de benadeelde op het moment van de feitelijke beschadiging terstond in zijn vermogen een nadeel lijdt dat in omvang gelijk is aan de waardevermindering die het vermogensbestanddeel heeft ondergaan. Dat die waardevermindering in het algemeen kan worden begroot op - men kan ook zeggen: wordt gelijkgesteld

48 Vgl. Klaassen, Schadevergoeding: algemeen, deel 2 (Mon. BW nr. B35) 2007/Io.

49 Zie onder meer J.M. Barendrecht \& H.M. Storm (red.), Berekening van schadevergoeding, Zwolle: W.E.J. Tjeenk Willink I995, p. 96, C.J.M. Klaassen, 'Het ontstaansmoment van schade in relatie tot de verschuldigdheid van wettelijke rente en faillissement', in: C.J.M. Klaassen \& A.J. Akkermans, Het moment van ontstaan van schade, Lelystad I998, p. 7 en Lindenbergh, in: GS Schadevergoeding, art. 6:96 BW, aant. 2.3.7 (online, laatst bijgewerkt I3 augustus 2015).

50 A.R. Bloembergen, Schadevergoeding bij onrechtmatige daad, Deventer: Kluwer 1965, nr. 45.

5 I T.E. Deurvorst, 'Abstracte schadeberekening en de expansie van de aanspraak op schadevergoeding', NTBR I996-2, p. 39-40. 
aan - de naar objectieve maatstaven berekende kosten van herstel, doet aan het terstond intreden van het vermogensnadeel niet af.

3I. Spier meent dat de omvang van de herstelkosten moet worden bepaald op 'het bedrag dat redelijke reparatie binnen redelijke termijn zou hebben gevergd'. Indien tussen het moment van beschadiging en het moment waarop daadwerkelijk tot herstel wordt overgegaan sprake zou zijn van een stijging of daling van de reparatietarieven, zal de benadeelde bij een prijsstijging immers kiezen voor een concrete vaststelling en bij een prijsdaling voor een abstracte, oftewel voor de variant die hem - achteraf bezien - de hoogste vergoeding oplevert. Als gevolg daarvan zou in veel gevallen de benadeelde uiteindelijk in een betere positie komen te verkeren dan wanneer de gebeurtenis niet had plaatsgevonden, zo betoogt Spier:

'De consequentie is dat de aansprakelijke persoon in een groot aantal gevallen teveel zal betalen. De benadeelde zal soms beter worden van het schade-evenement. Of dat het geval is, hangt af van louter toevallige factoren. Kortom: het toeval beheerst de uitkomst van het schadevergoedingsdebat. Dat is onwenselijk en onnodig. ${ }^{52}$

32. Ook na herstel kan een waardevermindering resteren. De benadeelde heeft recht op vergoeding van deze waardevermindering, ongeacht of hij tot verkoop of inruil overgaat.

Hierover gaat het arrest Schreuder/Van Driesten, waarin het draaide om de vaststelling van de waardevermindering wegens door een aanrijding toegebrachte schade aan een auto, resterend na - en ondanks - herstel van die beschadiging. Nu de waardevermindering niet volledig tot uitdrukking kwam in de omvang van de herstelkosten, speelde de vraag of de mindere waarde die een weliswaar gerepareerde auto heeft (aanvullend) moet worden vergoed, ook al wordt ze niet verkocht of ingeruild. En als het antwoord bevestigend zou luiden, moet de rechter de omvang daarvan bepalen naar het moment waarop hij oordeelt (dus ex post), of naar het moment direct na de schade (ex ante)? De Hoge Raad overweegt: '(...) dat de door de aanrijding beschadigde auto van Van Driesten na herstel van de beschadiging, ondanks dat herstel, een mindere waarde had dan hij zonder de aanrijding zou hebben gehad, omdat bij verkoop of inruil de gegadigde met het oog op de kans van verminderde deugdelijkheid van de auto, ondanks het herstel, daarvoor een lager bedrag zou geven dan hij gegeven zou hebben als de auto geen aanrijding had gehad.' Voorts overweegt de Hoge Raad '(...) dat het vermogen van den eigenaar door de aanrijding terstond een vermindering ondergaat gelijk aan de vermindering van de waarde van den auto, die het gevolg is van de omstandigheid, dat bij de waardebepaling in aanmerking moet worden genomen het op dat ogenblik te waarderen, door de aanrijding geschapen risico van het blijken van een gebrek., ${ }^{53}$

Die waardevermindering zou hieraan zijn toe te schrijven, dat de aan deze auto toe te kennen waarde mede wordt bepaald door de waardering van het risico dat de auto

52 J. Spier, 'De ongerechtvaardigde consequenties van abstracte en concrete schadeberekening', WPNR I995/6199, p. 7I2. Zie hierover kritisch R. Zwitser, 'De niet-bestaande keuze tussen abstracte en concrete schadeberekening', WPNR I996/6213, p. I45-I47 (voorzien van een naschrift door Spier).

HR I3 december 1963, NJ 1964/449 m.nt. G.J. Scholten (Schreuder/Van Driesten). 
ondanks het herstel ten gevolge van de aanrijding een gebrek zou hebben (er hangt nog een 'kwade geur' aan). Een aanrijdingsvrije auto vertegenwoordigt een hogere waarde, zo luidt de veronderstelling. ${ }^{54}$ Dit risico kan evenwel met de tijd afnemen, en daarmee dus ook waardevermindering die het gevolg is van de aanrijding. Dit 'fluctueren' of 'wegebben' van de waardevermindering van de auto neemt volgens de Hoge Raad niet weg, dat door de aanrijding terstond - dat wil zeggen op het moment direct na de reparatie - het vermogen van de eigenaar een vermindering ondergaat gelijk aan de vermindering van de waarde van de auto. Deze vermindering is het gevolg van de omstandigheid dat de kans van verminderde deugdelijkheid van de auto bij de ex antewaardebepaling in aanmerking moet worden genomen. De eigenaar heeft dus aanspraak op vergoeding van deze vermogensvermindering, ook al gaat hij in het geheel niet - of eerst op een later tijdstip - tot verkoop of inruil over, en ook al verwezenlijkt het risico zich niet en wordt dat gaandeweg kleiner. ${ }^{55}$ In de ogen van NJ-annotator Scholten heeft deze regel verstrekkende gevolgen:

'Consequentie is dus enerzijds dat als op het moment van oordelen al vaststaat dat de kwade kans in verband waarmee die waarde minder was, zich niet heeft gerealiseerd, bijv. omdat de auto dan de normale tijd heeft uitgediend, de eigenaar toch de oorspronkelijke waardedaling krijgt. En consequentie is anderzijds dat als na de reparatie een verborgen gebrek blijkt dat de auto waardeloos maakt en achteraf toch veroorzaakt blijkt door de aanrijding, hiermee niet mag worden gerekend, zelfs als de schade nog niet definitief is vastgesteld. ${ }^{96}$

Rutten is kritisch over deze uitspraak, niet alleen omdat er afbreuk wordt gedaan aan het beginsel van concrete schadeberekening - de benadeelde zou meer vergoed krijgen dan de daadwerkelijke schade wanneer hij de resterende waardevermindering vergoed krijgt terwijl hij de auto niet zal verkopen of inruilen - maar ook omdat het in strijd is met de door hem vooropgestelde 'grondregel' dat schade door de rechter moet worden vastgesteld op grond van de feiten die hem bekend zijn op het tijdstip van de einduitspraak (oftewel: ex post-schadevaststelling is de hoofdregel): 'Het is vaste jurisprudentie van de Hoge Raad, dat de rechter bij zijn beslissing rekening moet houden met een verandering van omstandigheden gedurende de loop van het geding, met gebeurtenissen die zich sedert de onrechtmatige daad of sedert de dagvaarding hebben voorgedaan, voorzover de partijen daarop een beroep hebben gedaan, tenzij dit beroep ingevolge art. I34 Rv uitgesloten zou zijn. (...) Als na de dagvaarding een nieuwe schade is ontstaan, of zekerheid is ontstaan over feiten waarover aanvankelijk slechts een verwachting bestond, moet de rechter van deze nieuwe feiten uitgaan. ${ }^{57}$

Het probleem dat Rutten hier signaleert, lijkt inherent aan de manier waarop de waardevermindering moet worden vastgesteld: de daarbij toe te passen 'abstractie' zit hem er nu juist in dat men ervoor kiest de latere ontwikkelingen niet mee te wegen. Er wordt

54 Zie over bedenkingen bij dit beweerde risico van achteraf blijkende gebreken Salomons, Schadevergoeding: zaakschade (Mon. BW nr. B38) I993/I9.

55 Soortgelijke vragen kunnen ook bij andere zaken dan auto's spelen. Zie bijv. Arbitrale beslissing (H. Schadee) 25 november 1965, S\&S 1966/26 (schepen), Rb. Rotterdam 24 januari 1975, NJ 1976/87 (kabels behorende bij een spoorbrug) en Hof Den Haag 23 maart 1995, VR 1996/29 (bomen).

56 Aldus Scholten in zijn NJ-noot onder HR I3 december 1963, NJ 1964/449 (Schreuder/Van Driesten).

57 L.E.H. Rutten, 'Het recht op schadeloosstelling van de eigenaar van een auto welke als gevolg van een aanrijding een waardevermindering heeft ondergaan', VR I964-4, p. 79-80. 
gekozen voor een zekere fixatie op die aanvankelijk geldende verwachtingen; de risicotaxatie naar het moment van beschadiging is dan (waarde)bepalend.

33. De voorgaande discussie roept wel de vraag op, in hoeverre er inderdaad sprake is van iets anders dan een concrete schadevaststelling - zoals onder andere Rutten en Deurvorst concluderen - wanneer de waardevermindering, die wordt geacht terstond te zijn ingetreden bij de feitelijke beschadiging van de zaak, wordt begroot op (naar objectieve maatstaven berekende) herstelkosten. Waardeert men het nadeel dat hier door waardevermindering in het vermogen terstond wordt geleden niet juist concreet - stelt men die schade immers niet gewoon vast met inachtneming van alle relevante omstandigheden? - maar wel met inachtneming van het moment van de feitelijke beschadiging als 'peildatum'?

\subsection{Waardevermindering van onroerende zaken}

34. Dat het bedrag, waarin de waardevermindering van een beschadigde zaak waarvan herstel mogelijk en verantwoord is kan worden uitgedrukt, in het algemeen gelijk zal zijn aan de naar objectieve maatstaven berekende kosten die met het herstel zullen zijn gemoeid, geldt ook bij de beschadiging van onroerende zaken..$^{5}$ Ten aanzien van onroerende zaken speelt wel de vraag of, en zo ja, hoe een 'losstaande' waardevermindering - dus niet een waardevermindering die in de voor herstel van beschadiging begrote kosten tot uitdrukking gebracht wordt - als vermogensschade voor vergoeding in aanmerking komt, bijvoorbeeld wanneer die waardevermindering slechts of vooral samenhangt met de kans dat er nog daadwerkelijk schade zal optreden. Dit zou als een equivalent kunnen worden gezien van de problematiek in het zojuist besproken Schreuder/Van Driesten-arrest: het probleem schuilt hem namelijk ook hier in het feit dat de aansprakelijke partij kan stellen dat er (nog) geen actuele schade is, en dat van een 'actualisatie' pas sprake zou zijn bij een mogelijke toekomstige verkoop van de zaak door de eigenaar. Dit raakt aan wat in de literatuur wel is aangeduid als 'belasting met een duurzaam risico' of 'belasting met de kwade kans op toekomstige schade'.59

35. De rechtspraak van de Hoge Raad indiceert dat een vermindering van de waarde van een onroerende zaak niet hoeft te zijn 'gerealiseerd' door verkoop, wil deze voor vergoeding in aanmerking komen.

Het arrest Binnendijk/Emi betrof een vordering tot vergoeding van waardevermindering van een onroerende zaak als gevolg van overhangende hoogspanningsdraden. Ingeval sprake is van een gedoogplicht in het kader van de Belemmeringenwet Privaatrecht een rechthebbende van een stuk grond moet dan toestaan dat in, op of boven die grond openbare werken worden aangebracht, in stand gehouden of gewijzigd - dan dient de schade die daaruit voortvloeit volledig te worden vergoed. De kantonrechter en de rechtbank wezen de vordering van Binnendijk af, omdat zijn schade nog niet concreet

58 HR I2 april 1985, NJ 1985/625 m.nt. W.C.L. van der Grinten en HR I juli 1993, NJ 1995/43 m.nt. C.J.H. Brunner (Den Haag/Van Schravendijk).

59 A.J. Akkermans, Proportionele aansprakelijkheid bij onzeker causaal verband (diss. Tilburg), Deventer: Kluwer 1997, p. I22. 
was geworden in de vorm van een lagere opbrengst bij verkoop van het goed of door een verminderde kredietwaardigheid. De Hoge Raad casseert evenwel: 'In deze overweging geeft de Rb. blijk van een onjuiste rechtsopvatting, aangezien de door aanleg en instandhouding van een werk als bedoeld in de Belemmeringenwet Privaatrecht veroorzaakte schade, bestaande in waardevermindering van een onroerend goed o.g.v. die wet volledig moet worden vergoed, en voor het bestaan van een aanspraak op vergoeding geenszins is vereist dat die waardevermindering op een of andere wijze tot uitdrukking is gekomen (in de terminologie van Rb. en Ktr.: "concreet" is geworden), bijv. in de vorm van een lagere opbrengst bij verkoop van het goed of doordat is gebleken dat de mogelijkheid hypothecair crediet te verkrijgen daardoor wordt beperkt. Hieraan doet niet af, dat de Belemmeringenwet Privaatrecht de rechter bij beoordeling van een aanspraak op schadevergoeding de vrijheid laat om vooralsnog geen vergoeding toe te kennen t.z.v. mogelijke, doch nog niet vaststaande schade, waarvan het bestaan afhankelijk is van nog niet voldoende bepaalbare gebeurtenissen of omstandigheden in de toekomst. Dat dergelijke gebeurtenissen en omstandigheden - mede - van invloed zouden zijn op de waardevermindering van Binnendijks perceel is ten processe noch gesteld noch gebleken. ${ }^{60}$

In het arrest Oranje Nassau Mijnen BV/Van den Broeck ging het om de vraag naar de vergoedbaarheid van 'doorgaande mijnschade'. Van den Broeck vorderde vergoeding van schade aan een hem in eigendom toebehorend woonhuis, dat degradaties en beschadigingen is gaan vertonen als gevolg van ondergrondse ontginningen door Oranje Nassau Mijnen BV. De vraag rees of naast een vergoeding van de reeds ontstane schade ook een vergoeding verschuldigd is voor de 'toekomstige nawerking' van de mijnexploitatie. De Hoge Raad overweegt: 'Hetgeen het Hof hieromtrent heeft geoordeeld komt hierop neer: dat het feit dat de schade ook thans nog doorgaat en dat de nawerking van de mijnexploitatie nog wel tien jaar meetbaar kan zijn, reeds thans een waardeverminderende invloed op het pand uitoefent omdat de verkoopwaarde daardoor reeds thans nadelig wordt beïnvloed; dat deze reeds thans bestaande schade moet worden gewaardeerd op $f 40$ ooo; dat dit bedrag tevens is te beschouwen als een afkoopsom ter zake van toekomstige waardeverminderingen. Dit oordeel geeft geen blijk van een verkeerde rechtsopvatting, ook niet indien de mogelijkheid in aanmerking wordt genomen dat een nieuwe eigenaar in de toekomst vergoeding van eventuele nieuwe mijnschade van Oranje Nassau Mijnen zou kunnen vorderen. ${ }^{6 r}$ De nawerking van de mijnexploitatie heeft dus 'thans' reeds een waardeverminderende invloed, die als vermogensnadeel voor vergoeding in aanmerking komt.

In lijn hiermee liggen ook de arresten Gemeente Maassluis/Van Koppen c.s. en Gemeente Dordrecht/Stokvast. In deze arresten ging het om gevallen van bodemverontreiniging. In het arrest Gemeente Maassluis/Van Koppen c.s. werd de gemeente Maassluis verantwoordelijk gehouden voor de bouw van woningen op door de gemeente verkochte verontreinigde grond. Ook hier speelde de vraag of de bewoners recht hadden op schadevergoeding, ook al verkochten zij hun woning niet. De Hoge Raad onderschrijft het oordeel van het hof: 'dat in een geval als het onderhavige de schade in verband met de waardedaling van een woning abstract mag worden berekend en dat reeds ten tijde van 's hofs beslissing aannemelijk was dat Van Koppen c.s. door de bodemverontreiniging schade hebben geleden. Deze oordelen moeten (...) aldus worden verstaan dat aannemelijk is dat Van

6o HR 2 februari i979, NJ I979/384 m.nt. F.H.J. Mijnssen (Binnendijk/Emi).

6I HR 23 mei I980, NJ I980/466 (Oranje Nassaumijnen). 
Koppen c.s. niettegenstaande het feit dat zij hun woning niet hebben verkocht, schade hebben geleden in de vorm van waardedaling van de woning als gevolg van de bodemverontreiniging, en dat deze schade voor abstracte berekening in aanmerking komt. ${ }^{62}$ In het arrest Gemeente Dordrecht/Stokvast ging het eveneens om bodemverontreiniging. Stokvast leed als koper schade doordat de grond die zij van de gemeente Dordrecht had gekocht en waarop zij huurwoningen bouwde, verontreinigd bleek te zijn. De gemeente bleek echter reeds vóór het moment van de vaststelling van de schade tot sanering te zijn overgegaan, en stelde daarom dat het tijdstip waarop alle saneringsmaatregelen waren uitgevoerd (en de markt ter plaatse is gestabiliseerd) als peildatum moest worden gekozen. De Hoge Raad overweegt: 'Mede met het oog op hanteerbaarheid van de methode van schadebegroting, rechtvaardigt de aard van zodanige schade dat het de rechter vrijstaat bij het begroten daarvan te abstraheren van bepaalde, de bijzondere situatie van de benadeelde eigenaar betreffende, omstandigheden. In het bijzonder kan buiten beschouwing worden gelaten dat de eigenaar de woningen niet heeft verkocht (...). Indien en voor zover echter ten tijde van de vaststelling van de schade door de rechter, de aanvankelijk opgetreden waardevermindering van de woningen ongedaan blijkt te zijn gemaakt door een van overheidswege uitgevoerde bodemsanering in het gebied waar de woningen zich bevinden, is dit waardeherstel een niet met de individuele situatie van de eigenaar samenhangende omstandigheid die redelijkerwijs in aanmerking behoort te worden genomen om te voorkomen dat meer dan de werkelijk geleden schade wordt vergoed. ${ }^{63}$

36. De Hoge Raad maakt in het arrest Gemeente Dordrecht/Stokvast onderscheid tussen de met de individuele situatie van de eigenaar samenhangende omstandigheden waarvan mag worden geabstraheerd, en de niet daarmee samenhangende omstandigheden, die wel in aanmerking moeten worden genomen (zoals dus de omstandigheid dat de aanvankelijk opgetreden waardevermindering ten tijde van de schadevaststelling ongedaan blijkt te zijn gemaakt door een van overheidswege uitgevoerde bodemsanering). Dat suggereert dat de abstractie toch ook weer niet zo 'absoluut' is, en dat bovendien wel degelijk situaties denkbaar zijn waarin moet worden voorkomen dat meer dan de werkelijk geleden schade zou worden vergoed indien niet wordt afgeweken van de abstracte methode. Of hier werkelijk sprake is van een dergelijke uitzondering op of verfijning van een regel van abstracte schadeberekening, wordt door Bloembergen betwijfeld: hij acht de redenering dat de sanering een niet met de individuele situatie van de eigenaar samenhangende omstandigheid is (omdat niet alleen Stokvast, maar alle eigenaren in het betrokken gebied op dezelfde wijze van de sanering zouden hebben geprofiteerd) niet overtuigend. Volgens hem draait het hier in essentie om vergoeding van schade in natura:

'De overheid saneert (herstelt) de bodem en maakt daarmee de aanvankelijk opgetreden waardevermindering van de huizen ongedaan (...). De eigenaar van de woningen heeft dan in zoverre geen schade meer en kan dus ook in zoverre geen

62 HR 9 oktober 1992, NJ I994/286 m.nt. C.J.H. Brunner (Gemeente Maassluis/Van Koppen c.s.),

63 HR 28 april 2000, NJ 2000/690 m.nt. A.R. Bloembergen (Gemeente Dordrecht/Stokvast), r.o. 3.4.2. 
schadevergoeding meer vorderen. Een uitzondering op of verfijning van een regel van abstracte schadeberekening valt hierin niet te onderkennen. ${ }^{64}$

Tegelijkertijd onderstreept de Hoge Raad met dit arrest (weer) dat het de rechter vrijstaat bij het vaststellen van de schade te abstraheren van bepaalde omstandigheden, in het bijzonder de situatie waarin de eigenaar de woningen niet heeft verkocht.

37. Soms doen zich gevallen voor waarin het tijdstip waarop de waardevermindering wordt geacht te zijn ingetreden onbepaalbaar is, en kan de rechter die waardevermindering dus niet bepalen naar 'het moment' waarop deze zich heeft voorgedaan. De Rechtbank Noord-Nederland liep tegen dit probleem aan in de zaak waarin het draaide om de waardevermindering van huizen in Groningen als gevolg van aardbevingen die worden veroorzaakt door gaswinning.

De Nederlandse Aardolie Maatschappij (NAM) wordt door een collectief van inwoners van het getroffen gebied aansprakelijk gehouden voor de schade die wordt geleden als gevolg van bodemdaling, veroorzaakt door gaswinning; een vordering die primair wordt gebaseerd op de risicoaansprakelijkheid van artikel 6:I77 BW. Partijen zijn verdeeld over de vraag of de schade bestaande uit waardevermindering als gevolg van de aardbevingen direct (dus ongeacht verkoop en fysieke schade) voor vergoeding in aanmerking kan komen of dat de omvang van die waardevermindering dermate onzeker is dat deze op een later moment moet worden vastgesteld. In lijn met de rechtspraak van de Hoge Raad overweegt de rechtbank: 'dat de Stichting WAG en de woningcorporaties in beginsel reeds nu (ongeacht verkoop en - zoals door NAM niet is bestreden - ongeacht of fysieke schade is opgetreden) aanspraak kunnen maken op vergoeding van de schade die zij hebben geleden als gevolg van aardbevingen die door gaswinning door NAM zijn veroorzaakt en die bestaat uit waardevermindering van onroerende zaken die zijn gelegen in het aardbevingsgebied. ${ }^{65}$ Bij de vaststelling van het tijdstip waarop de waardevermindering is opgetreden doet zich in het onderhavige geval de complicatie voor dat waardevermindering zich niet van het ene op het andere moment openbaart. De waardevermindering van het onroerend goed in het Groningse aardgasveld heeft zich glijdend gemanifesteerd. Op enig moment werd manifest dat de aardbevingsproblematiek ernstiger was dan wellicht aanvankelijk gedacht. Langzaam ontstond onrust bij de bewoners in het aardbevingsgebied, die steeds meer toenam door de toenemende frequentie van bevingen, de zwaarte daarvan en het ontstaan van fysieke schade. (...) Dit brengt met zich mee dat in dit bijzondere geval geen exacte datum kan worden aangewezen waarop de schade door waardevermindering zich heeft voorgedaan.'

38. Men zou kunnen zeggen dat er sprake is van een geleidelijk intredende waardevermindering (of een waardevermindering die zich glijdend heeft gemanifesteerd), waardoor het 'moment van beschadiging' dat aan de waardevermindering ten grondslag ligt nogal diffuus is.

64 Bloembergen in zijn NJ-noot onder HR 28 april 2000, NJ 2000/69o (Gemeente Dordrecht/Stokvast).

65 Rb. Noord-Nederland 2 september 2015, NJF 2015/4I9, r.o. 4.4.I8. 
De Rechtbank Noord-Nederland is daarom van oordeel: 'dat begroting van de omvang van de schade door waardevermindering in dit geval kan plaatsvinden door ten tijde van het moment van taxatie na een desbetreffende vordering, de werkelijke waarde van het onroerend goed te vergelijken met de waarde zonder de aardbevingsproblematiek, rekening houdend met alle bestaande en toekomstige omstandigheden die aantoonbaar en duurzaam van invloed kunnen zijn op de schadebegroting. Onder de gegeven omstandigheden acht de rechtbank hantering van de taxatiedatum als uitgangspunt voor de waardering het meest in overeenstemming met de redelijkheid en de billijkheid, zodat op die grond een afwijking van het beginsel dat waardering plaatsvindt naar de datum waarop de waardevermindering is opgetreden, gerechtvaardigd is te achten. $^{.66}$

39. Stelt men de peildatum voor de begroting van de waardeverminderingsschade op het moment van taxatie, dan kan het voor de omvang van de vergoedingsplicht wel sterk een kwestie van 'timing' worden: men kan immers verwachten dat het in het belang van de benadeelden is om ten aanzien van de taxatie op een voor hen zo 'gunstig' mogelijk tijdstip aan te sturen, oftewel het 'dieptepunt' in waarde. Het komt erop neer dat - wanneer niet tot verkoop over wordt gegaan - de gok een keer moet worden genomen. Verheij verzuchtte kort voor de uitspraak van de rechtbank inzake de gaswinning in Groningen:

'Schade is het verschil tussen twee toestanden - een hypothetische toestand en de feitelijke toestand - en dat veronderstelt een vast punt. Er valt geen vergelijking te maken als er geen duidelijkheid bestaat over de feitelijke toestand. Schade is meer dan louter een momentopname. Dit lijkt een principieel bezwaar tegen de verplichting om nu af te rekenen, maar er zit ook een praktische kant aan. Want wat moet als peildatum gebruikt worden? De waardevermindering zoals die vandaag valt te constateren? Of de waardevermindering zoals die een half jaar geleden of vorig jaar uitpakte? Het lijkt allemaal willekeurig. ${ }^{67}$

40. De vraag is of in dit soort gevallen schade inderdaad meer is dan 'louter een momentopname'. Het vermogensnadeel dat hier wordt geleden hangt immers samen met de - als gevolg van alle commotie en onzekerheden - (ook) in waarderingsopzicht uiterst instabiele situatie. Zeker hier geldt dat de schadeomvang sterk afhangt van het bij de schadevaststelling tot uitgangspunt genomen tijdsmoment. Een (aantrekkelijk) alternatief voor het aanwijzen van één beslissend moment lijkt er wat betreft de vergoeding van de waardevermindering ook niet te zijn: dat zou immers betekenen dat ten aanzien van iedere latere waardestijging of -daling partijen iets van elkaar te verlangen zouden hebben. Of zoals Verheij het verwoordt:

'Vergoeding van waardevermindering zou dan een soort gezelschapsspel worden ("gezelligheid voor het hele gezin én voor de hele provincie!") waarbij partijen elkaar

66 Rb. Noord-Nederland 2 september 20I5, NJF 20I5/4I9, r.o. 4.4.I9.

67 A.J. Verheij, 'Geldt het Burgerlijk Wetboek nog in Groningen?', Nederlands Juristenblad 2015/I250, p. I737. 
op regelmatige basis aanspreken ter vergoeding van schade wegens het verder dalen of weer stijgen van de waarde. ${ }^{68}$

\subsection{Achteruitgang of vermindering als voorwaarde voor schadevergoeding?}

4I. In de hiervoor besproken gevallen waarin een abstracte wijze van schadevaststelling werd besproken, lijkt niet relevant of de benadeelde er achteraf bezien op vooruit of achteruit is gegaan: de te vergoeden waardevermindering treedt doorgaans immers terstond in. Uit later opkomende omstandigheden kan evenwel blijken dat de nieuwe situatie voor de aanvankelijk benadeelde per saldo geen achteruitgang inhoudt.

Dat probleem kwam aan de orde in het arrest Griffioen/De Groot. Partijen waren een ruilovereenkomst aangegaan betreffende gedeelten van twee aangrenzende percelen grasland. Een van beiden (eiser in cassatie) had de intentie om op het door hem te ontvangen gedeelte zijn boomkwekerij uit te breiden, maar hij was voor de realisering daarvan afhankelijk van een wijzing van een bestemmingsplan (ten aanzien waarvan dan ook een ontbindende voorwaarde werd opgenomen). Er ontstaat vervolgens een geschil over de vraag of deze verkrijger tijdig een beroep heeft gedaan op die ontbindende voorwaarde, dat tot een procedure leidt waarbij conservatoir beslag wordt gelegd op het stuk grasland van eiser dat bij de ruil was betrokken. Eiser wordt echter in het ongelijk gesteld en veroordeeld tot medewerking aan de afwikkeling van de ruilovereenkomst. Eiser wordt daarbij veroordeeld tot het uitvoeren van enige werkzaamheden op zijn land, zoals bij de ruil was overeengekomen. In hoger beroep wordt het betreffende vonnis echter vernietigd, omdat het hof van oordeel is dat wél tijdig een beroep is gedaan op de ontbindende voorwaarde in de ruilovereenkomst. Daarop vordert eiser vergoeding van de schade die hij lijdt doordat hij - achteraf zinloos gebleken - werkzaamheden aan zijn perceel heeft laten verrichten. Voorwerp van debat is de vraag of de - abstract berekende - kosten die gemoeid gaan met herstel in de 'oude toestand' voor vergoeding in aanmerking komen, nu de betreffende werkzaamheden de waarde of de exploitatiemogelijkheid van de grond, naar later bleek, niet hebben aangetast. Eiser had namelijk inmiddels een kwalitatieve verplichting op zich genomen om een gedeelte van het perceel niet meer te gebruiken voor landbouw, waarvoor hij ook subsidie ontving. De Hoge Raad overweegt: 'In beginsel dient de schadevergoeding de benadeelde zoveel mogelijk in de toestand te brengen waarin hij zou hebben verkeerd indien de schadeveroorzakende gebeurtenis zou zijn uitgebleven, hetgeen meebrengt dat de omvang van de schade wordt bepaald door een vergelijking van de toestand zoals deze in werkelijkheid is met de toestand zoals die (vermoedelijk) zou zijn geweest indien het schadeveroorzakende feit niet zou hebben plaatsgevonden. Als die vergelijking echter aan het licht brengt dat de nieuwe toestand voor de partij die schadevergoeding verlangt geen achteruitgang (waaronder mede te verstaan: waardevermindering en vermindering van exploitatiemogelijkheden van een haar toebehorende zaak) inhoudt ten opzichte van de oude, en die partij er geen rechtens te respecteren belang bij heeft dat de oude toestand wordt hersteld, kan de rechter zonder enige rechtsregel te schenden

68 A.J. Verheij, ‘Geldt het Burgerlijk Wetboek nog in Groningen?', Nederlands Juristenblad 2015/1250, p. 1738 . 
tot het oordeel komen dat er geen vermogensschade is geleden en op die grond de vordering tot vergoeding van de kosten van herstel in de oude toestand afwijzen. ${ }^{69}$

Interessant zijn vervolgens ook de overwegingen van de Hoge Raad die meer specifiek zien op hoe moet worden omgegaan met de later opkomende omstandigheden bij de vaststelling van schade. In cassatie werd immers aangevoerd dat niet ter zake zou doen dat eiser geen aanleiding of noodzaak meer zou hebben haar percelen in de oude staat terug te brengen, omdat de door hem geleden schade moet worden berekend naar het moment van de verrichte werkzaamheden. 'Dit betoog gaat terecht uit van het beginsel dat de omvang van de schade, die naar objectieve maatstaven wordt begroot, dient te worden berekend naar het moment waarop zij wordt geleden. Gebeurtenissen van later datum kunnen onder omstandigheden evenwel meebrengen dat van de getroffen eigenaar in redelijkheid kan worden verlangd dat hij zijn aanspraak beperkt. Voormeld beginsel laat bovendien onverlet dat uit gebeurtenissen van later datum soms gevolgtrekkingen kunnen worden gemaakt met betrekking tot de situatie die bestond op het tijdstip waarop de schade werd geleden. De blijkbaar aan de klacht ten grondslag liggende opvatting dat omstandigheden die zich na het lijden van de schade voordoen, nimmer van belang kunnen zijn bij de schadebegroting is dus onjuist, zodat de klacht ongegrond is. ${ }^{70}$

42. Uit gebeurtenissen van later datum kunnen dus gevolgtrekkingen worden gemaakt met betrekking tot de situatie die bestond op het tijdstip waarop de schade werd geleden. Lastig is evenwel om hieruit op te maken wat precies de betekenis is van omstandigheden die zich na het lijden van de schade voordoen. De overwegingen suggereren immers dat de schade reeds is geleden, en dat de omvang van de schade ook naar het moment waarop deze wordt geleden dient te worden bepaald.

\subsection{Schadevergoeding wegens ontbinding van een koopovereenkomst}

43. Ook bij ontbinding van een koopovereenkomst kan een 'abstracte wijze van schadevaststelling' worden toegepast, wat eveneens als een vorm van fixatie in de tijd kan worden gezien. Afdeling 7.I.7 BW behelst een bijzondere regeling ten aanzien van de koopovereenkomst, die voortbouwt op de algemene schadevergoedingsregels uit afdeling 6.I.Io BW. De bepalingen van afdeling 7.I.7 gelden zowel wanneer de koper als wanneer de verkoper tot ontbinding van de koopovereenkomst overgaat. In deze specifieke afdeling liggen vastgelegd een aanspraak op een abstracte wijze van schadevaststelling indien het gaat om zaken met een dagprijs (artikel 7:36 BW), en een aanspraak op een concrete schadeberekening in geval van een dekkings(ver)koop (artikel 7:37 BW). ${ }^{7 \mathrm{I}}$ Daarnaast wordt geëxplici-

$\overline{69}$ HR II januari 20I3, NJ 20I3/48 (Griffioen/De Groot), r.o. 3.5.

70 HR II januari 20I3, NJ 20I3/48 (Griffioen/De Groot), r.o. 3.7.

$7 \mathrm{I}$ In de Principles of European Contract Law (PECL) is een vergelijkbare regeling opgenomen, die niet beperkt is tot koopovereenkomsten maar betrekking heeft op elk soort contract: zie art. 9:506 (vergelijkbaar met art. 37) en art. 9:507 (vergelijkbaar met art. 36) PECL. Zie, in vergelijking met het Nederlandse recht, H.N. Schelhaas, 'Comment on Art. 9:506 and 9:507 PECL', in: H.N. Schelhaas e.a. (red.), The Principles of European Contract Law and Dutch Law - A Commentary, Nijmegen/The Hague/London/Boston: Ars Aequi/Kluwer Law International 2002, p. 4I7-423. 
teerd dat een hogere schadevergoeding niet uitgesloten is ingeval er meer schade is geleden (artikel 7:38 BW)..$^{72}$

44. Artikel 7:36 BW ziet op de zogenoemde 'transactieschade': het nadelig verschil tussen de waarde van de zaak ten tijde van de wanprestatie en de contractsprijs. Het is van toepassing op zaken met een dagprijs: een prijs die kan worden vastgesteld aan de hand van veilingoverzichten of koersstaten voor zaken van de overeengekomen kwaliteit en soort, op de markt waar de koop plaatsvond. ${ }^{73}$ De wegens de ontbinding te vergoeden schade wordt gelijkgesteld aan het verschil tussen de in de overeenkomst vastgestelde prijs en de dagprijs. ${ }^{74}$ Ingevolge artikel 7:36 BW is niet van belang hoe de koper verder ten aanzien van de goederen zou hebben gehandeld, en het maakt dus verder niet uit of de koper in feite minder schade heeft geleden. Daarvan kan dus in zekere zin worden 'geabstraheerd', door de schade te bepalen op de vermogensvermindering ten tijde van de wanprestatie. Een ander perspectief heeft te gelden wanneer het verschil tussen de bedongen prijs en een dekkingskoop wordt gevorderd, oftewel in de situatie waarin de koper zich genoodzaakt ziet de zaak van een ander dan de verkoper te betrekken. In dat geval wordt immers vergoeding van op concrete wijze vastgestelde schade gevorderd: concreet in die zin dat het dan bij de schadevaststelling gaat om een vergelijking met de dekkingskoop zoals die later daadwerkelijk door de benadeelde is gesloten.

45. De koper is in beginsel vrij om te kiezen voor de in artikel 7:36 BW voorziene abstracte dan wel voor de in artikel 7:37 BW voorziene concrete wijze van schadevaststelling. ${ }^{75}$ Kiest de koper voor de abstracte weg, dan dient hij te stellen - en zo nodig te bewijzen - wat de hoogte van de ten tijde van de tekortkoming geldende dagprijs (of de in artikel 7:36 lid 2 BW bedoelde marktprijs) van de betrokken zaken is. Volgt de koper de weg van artikel 7:37 BW, dan rust op hem de bewijslast dat, en voor welke prijs, hij een redelijke dekkingskoop heeft gesloten. De redelijkheid kan hier onder meer met zich brengen dat bij een stijging van prijzen niet onnodig lang wordt gewacht met een dekkingskoop; als peildatum geldt dan ook de dag waarop redelijkerwijs een dekkingskoop kan worden gesloten..$^{7}$

46. De schade kan worden bezien op het niveau van het vermogen als geheel: wanneer de koper op de peildatum (de dag van de wanprestatie) twee balansen van zijn vermogen had opgemaakt, een met en een zonder het gekochte, dan zou het verschil tussen beide het verschil tussen de contractsprijs en de dagprijs zijn, zo

72 Dezelfde aansprakelijkheid vestigende gebeurtenis kan immers ook nog andere schadeposten als gevolg hebben, zoals gederfde winst, exploitatieverlies, een aan een subkoper verschuldigde boete of schadevergoeding, kosten die door de wanprestatie nutteloos geworden zijn enzovoort. Zie voor een overzicht Asser/Hijma 7-I^ 2013/478.

73 Vgl. H.N. Schelhaas, in: GS Bijzondere overeenkomsten, Afdeling 7 Boek 7 BW, aant. A en Wessels, Koop: algemeen (Mon. BW B65a) 2010/50.

74 Dit wordt in het algemeen vastgesteld aan de hand van veilingoverzichten of koersstaten voor zaken van de overeengekomen kwaliteit en soort (zie art. 7:36 lid $2 \mathrm{BW}$ ).

75 HR 6 maart I998, NJ I998/422 m.nt. A.R. Bloembergen (Interfood/Lycklama).

76 Zo valt op te maken uit onder meer HR 28 januari I977, NJ I978/I74 m.nt. A.R. Bloembergen (Pootaardappelen). Zie ook Asser/Hijma 7-I* 2013/485. 
luidt de redenering. ${ }^{77}$ Dit roept de vraag of op deze wijze van schadevaststelling, die een toepassing is van het uitgangspunt dat wanneer aan een schuldeiser een zaak van een bepaalde waarde onthouden wordt, hij op dat moment in zijn vermogen een nadeel lijdt gelijk aan het verschil tussen de contractsprijs en de dagprijs ten dage van de niet-nakoming, niet ook eerder als concreet - het gaat immers ook om de op dat moment geldende dag- of marktprijs van de betrokken zaken - dan als abstract moet worden gezien.

\subsection{Vervangende schadevergoeding wegens uitblijven van een overeengekomen prestatie}

47. Ingeval vervangende schadevergoeding wordt gevorderd wegens gedeeltelijke niet-nakoming van een verbintenis tot het verrichten van een bepaalde prestatie, moet de schade worden begroot op basis van de vermogensvermindering die ten tijde van de niet-nakoming van de te vervangen prestatie wordt geleden.

Zo valt af te leiden uit het arrest Sparrow en Heemskerk/Van Beukering-Louwers. In die zaak ging het om de verkoop en levering van een pand door Van Beukering-Louwers aan Sparrow en Heemskerk. Van Beukering-Louwers had reeds eerder met een aannemingsbedrijf een aannemingsovereenkomst gesloten met betrekking tot de restauratie van het huis. Van Beukering-Louwers heeft zich jegens Sparrow en Heemskerk verbonden tot strikte nakoming van deze aannemingsovereenkomst. De aannemer levert ondeugdelijk werk, waardoor Van Beukering-Louwers tegenover Sparrow en Heemskerk tekortschiet. Sparrow en Heemskerk vorderen vervangende schadevergoeding van Van Beukering-Louwers, maar krijgen tegengeworpen dat er geen schade is geleden omdat er geen herstel heeft plaatsgevonden en het pand desondanks reeds gunstig door Sparrow en Heemskerk is doorverkocht. De Hoge Raad overweegt: 'In een dergelijk geval moet de schade worden begroot op basis van de vermogensvermindering die ten tijde van de niet-nakoming door de tot de prestatie gerechtigde is geleden ten opzichte van de situatie waarin hij zou zijn geraakt bij behoorlijke nakoming van de verbintenis, en is de latere verkoop van het huis een omstandigheid waaraan in het kader van een vordering tot vervangende schadevergoeding als de onderhavige geen betekenis toekomt. ${ }^{78}$

48. Kortom: het moment van de niet-nakoming veroorzaakt terstond een waardevermindering, die ook naar dat moment begroot moet worden, en waarbij dus geen betekenis toekomt aan later opkomende omstandigheden. Hijma onderstreept dat het hier niet gaat om een abstracte vorm van schadeberekening:

'Vervangende schadevergoeding ziet niet op het vermogen van de schuldeiser in algemene zin, maar strekt tot substitutie van één bepaald vermogensbestanddeel (in casu: de vordering tot uitvoering van het afgesproken restauratiewerk). De waardering van dat specifieke gemis staat, naar haar aard, los van de wederwaardigheden van het pand

77 Vgl. Meijers in zijn NJ-noot onder HR I8 november I937, NJ I938/269 (Engelse Kolenstaking), die naar wij vermoeden per abuis opmerkt dat het verschil tussen beide de marktprijs is.

78 HR 26 april 2002, NJ 2004/210 m.nt. J. Hijma (Sparrow en Heemskerk/Van Beukering-Louwers), r.o. 4.3.2. 
waarop de toegezegde prestatie - toevallig - betrekking heeft. Dat is geen kwestie van abstracte schadeberekening (vgl. art. 6:97), maar een consequentie van het beperkte blikveld dat dit type schadevergoeding eigen is. ${ }^{79}$

\subsection{Slot}

49. Het voorgaande laat zien dat verschillende wijzen van schadevaststelling die wel als abstract worden geduid, in essentie lijken neer te komen op een zekere tijdsfixatie. Of daarmee daadwerkelijk wordt 'geabstraheerd' van later opkomende omstandigheden, hangt af van de vraag of die latere omstandigheden wel relevant zijn binnen het kader van het te hanteren schadebegrip. Waar een specifieke schadepost moet worden begroot op de waardevermindering of vermogensvermindering die met de aansprakelijkheidscheppende gebeurtenis terstond (en dus volledig) intreedt, gaat het om een waardering naar dat specifieke tijdsmoment. Dan is dus de naar dat ene moment gemeten waarde in het economisch verkeer bepalend, en doet niet ter zake of de benadeelde naar een later gemeten tijdstip alsnog in een minder gunstige of juist gunstiger vermogenspositie is terechtgekomen.

50. In de discussie over abstracties bij de begroting van schade komt het in dit preadvies centrale tijdsverloopprobleem met regelmaat terug. In essentie lijkt het daarbij steeds te draaien om de vraag hoe men moet omgaan met de later opkomende informatie, die iets leert over de positie waarin de benadeelde uiteindelijk verkeert. Waar men als uitgangspunt neemt dat de benadeelde exact moet worden gecompenseerd lijkt het in sommige gevallen tegenintuïtief om latere omstandigheden bij de schadebegroting buiten beschouwing te laten: bij compensatoire schadevergoeding mag de benadeelde in beginsel immers niet slechter maar ook niet beter worden van de aansprakelijkheidscheppende gebeurtenis. Men kan dit natuurlijk ook omdraaien: het komt de 'exactheid' van de schadebegroting juist ten goede wanneer men van een bepaald ankerpunt in de tijd kan uitgaan. ${ }^{80}$ De waarde van het object waarin de schade bestaat, hangt evenwel samen met de verwachtingen die heersen op dat moment, en dat betekent dat men soms moet 'wegkijken' van later opkomende omstandigheden (en dus ex ante schade vaststelt naar een in het verleden gelegen moment).

5I. Het voorgaande doet de vraag rijzen of het niet veel meer voor de hand ligt om de rechtvaardiging voor wat wel de stempel 'abstractie' draagt, te zoeken in de tijdgebondenheid van de vaststelling van een bepaalde schade - wanneer de benadeelde op het moment van de feitelijke beschadiging reeds terstond in zijn vermogen is getroffen hoeven latere ontwikkelingen niet te worden afgewacht - in plaats van de 'doelmatigheid'.

79 NJ-annotator Hijma onder HR 26 april 2002, NJ 2004/2Io (Sparrow en Heemskerk/Van BeukeringLouwers), onder punt 4. Instemmend ook S.D. Lindenbergh, 'Over wat schade is... en waarom het bij de vaststelling daarvan in de praktijk zo dikwijls mis gaat', WPNR 2010/6867, p. 908-909, die benadrukt dat een sterker op de waarde van de prestatie toegespitste verwoording aantrekkelijk(er) was geweest, omdat de door de Hoge Raad gekozen formulering letterlijk genomen - onbedoeld? - ook gevolgschade zou omvatten.

80 Vgl. R. Zwitser, 'Abstracte of concrete schadeberekening: een verwarrend onderscheid', WPNR I980/5517, p. 326-327. 


\section{$5 \quad$ Voortdurende en toekomstige schade}

\section{I Inleiding: schade die zich over een periode uitstrekt}

52. Men pleegt wel een onderscheid te maken tussen zogenoemde 'momentschade' en 'voortdurende schade'. Onder momentschade kan worden verstaan schade die eenmalig in zijn geheel wordt geleden (zoals het hiervoor besproken vermogensnadeel dat terstond intreedt als gevolg van de waardevermindering van een zaak) waar voortdurende schade zich daarentegen over een zekere periode uitstrekt en dus successievelijk wordt geleden. De schade 'groeit' dan dus over een bepaalde tijdsperiode en wordt dus telkens bij gedeelten geleden. ${ }^{8 \mathrm{r}}$ Dat gebeurt mogelijk met een zekere regelmaat (periodiek), zoals het geval is bij het wegvallen van inkomen wegens arbeidsongeschiktheid, dat anders per maandelijkse loonbetaling zou zijn vergaard. Dat kan overigens ingewikkelder liggen als het gaat om gederfde winst, die niet steeds op vaste momenten zou zijn gemaakt. Voortdurende schade kan ook worden gezien als een 'reeks van momentschades': het gaat immers om opeenvolgende momenten waarop sprake is van een vermindering in het vermogen ten opzichte van het vermogen in de situatie zonder aansprakelijkheidscheppende gebeurtenis. Men pleegt die 'momentschades' wel onder één schadepost te scharen omdat zij steeds op dezelfde oorzaak kunnen worden teruggevoerd (het missen van inkomsten door voortdurende arbeidsongeschiktheid, het terugkerend maken van kosten wegens een permanente zorgbehoefte, het derven van winsten door het uitblijven van een bedrijfsuitbreiding enzovoort).

53. Wat als reeds geleden en als nog te lijden schade moet worden gezien, zal steeds afhangen van het moment waarop de schade wordt vastgesteld: dat tijdstip vormt de cesuur. ${ }^{82}$ Ten aanzien van het moment dat bepalend is voor de vaststelling van schade die zich over een periode uitstrekt, vallen drie modaliteiten te onderscheiden:

- voorafgaand aan de schadeperiode (de gehele schadeperiode wordt ex ante vastgesteld);

- lopende de schadeperiode (de reeds ingetreden schade wordt ex post en de toekomstige schade ex ante vastgesteld);

- na afloop van de schadeperiode (de gehele schade wordt ex post vastgesteld).

Het gaat hier dus - wanneer men spreekt van het moment waarop schade wordt vastgesteld - altijd om schade die reeds is geleden, schade die in de toekomst valt te verwachten of mogelijk beide. ${ }^{83}$ Hierbij verdient opmerking dat de term 'schadeperiode' een min of meer begrensde tijdruimte veronderstelt, oftewel het ontstaan en bestaan van schade en het ophouden te bestaan daarvan. Beide begrenzingen kunnen problematisch zijn. Hét moment waarop schade ontstaat,

8I Vgl. A-G Huydecoper in zijn conclusie voor HR 7 december 200I, NJ 2002/576 m.nt. J.B.M. Vranken (Gemeente Leeuwarden/Los), onder punt Io.

82 Vgl. A.R. Bloembergen, Schadevergoeding bij onrechtmatige daad, Deventer: Kluwer I965, nr. 20.

83 Dit is onzes inziens niet heel anders wanneer schade periodiek en dus lopende de schadeperiode wordt begroot: men deelt dan slechts de schadeperiode op in meerdere tijdvakken - en dus meerdere vaststellingsmomenten - zodat de uiteindelijke vergoeding meer gelijke tred houdt met het daadwerkelijke schadeverloop. 
is niet steeds eenduidig aan te wijzen maar zal afhangen van de feitelijke situatie, het type schade in kwestie en de rechtsfiguur die aan de orde is.$^{84}$ Ook het moment waarop de schade ophoudt te bestaan kan lastig bepaalbaar zijn: de nadelige gevolgen van een gebeurtenis kunnen zich uiteindelijk uitstrekken tot het moment waarop het rechtssubject dat haar lijdt zelf 'ophoudt te bestaan' (bijvoorbeeld bij personenschade die bestaat in een hulpbehoevendheid die zal voortduren tot het slachtoffer komt te overlijden).

\subsection{Toekomstige schade: goede en kwade kansen}

54. Artikel 6:105 BW beoogt handvatten te bieden voor de begroting en vergoeding van schade, die zich uitstrekt over een langere periode en dus (voor een belangrijk deel) in de toekomst wordt geleden. ${ }^{85}$ Het betreft hier een begroting bij voorbaat: het gaat om schade die waarschijnlijk in de toekomst zal worden geleden. Een complicatie bij de vaststelling van voortdurende schade is dat de bij de schadevaststelling met elkaar te vergelijken scenario's zich ook nog in de toekomst kunnen uitstrekken. Het is dan niet alleen noodzaak om te bepalen hoe de hypothetische situatie zonder de schadeveroorzakende gebeurtenis zou zijn geweest, maar ook om te bepalen hoe de werkelijke situatie zich in de toekomst nog zal ontwikkelen. Het is dus nodig om zicht te krijgen op twee toekomstige situaties, waarvan er één volstrekt hypothetisch is. ${ }^{86}$ Daarom kunnen zij niet worden vastgesteld zonder de 'afweging van goede en kwade kansen', oftewel het verdisconteren van toekomstige onzekere gebeurtenissen. ${ }^{87}$ De rechter moet hier een inschatting maken, waarbij het aankomt op de redelijke verwachtingen ten aanzien van toekomstige ontwikkelingen. ${ }^{88}$ Daarbij komt de rechter weliswaar een zekere mate van vrijheid toe, maar geldt onverminderd dat de schade in beginsel volledig moet worden vergoed en concreet moet worden vastgesteld.

55. De stelplicht en de bewijslast ten aanzien van de vraag of er schade is geleden of in de toekomst zal worden geleden rust in beginsel op de eisende partij. De Hoge Raad komt hem daarbij wel enigszins tegemoet.

In zijn arrest Vehof-Vasters/Helvetia, waarin het ging om toekomstige personenschade als gevolg van een verkeersongeval en de vraag of het slachtoffer een cursus tot bejaardenverzorgster zou hebben afgerond, overweegt de Hoge Raad dat: '(...) geen strenge eisen mogen worden gesteld met betrekking tot het te leveren bewijs van (schade wegens het derven van) de arbeidsinkomsten die de benadeelde in de toekomst zou hebben genoten in de hypothetische situatie dat het ongeval niet zou hebben plaatsgehad: het is immers de aansprakelijke veroorzaker van het ongeval die aan de benadeelde

84 Lindenbergh, Schadevergoeding: algemeen, deel 1 (Mon. BW nr. B34) 20I4/35. Men kan in het kader van voortdurende schade ook spreken van het 'aanvangsmoment van de schadeperiode' of van het moment waarop de schade 'intreedt'.

85 Overigens wordt ook in art. I0:I02 PETL (Principles of European Tort Law) gedoeld op de mogelijkheid van vergoeding van nog niet ingetreden schade bij voorbaat.

86 Vgl. T. Hartlief, 'Prognoses in het personenschaderecht', AV\&S 2005-5, p. I6o.

87 TM, Parl. Gesch. BW Boek 6, p. 336.

88 Zie HR I5 mei I998, NJ I998/624 (Vehof-Vasters/Helvetia), HR I3 december 2002, NJ 2003/2I2 (B./Olifiers) en HR 30 november 2007, NJ 20I2/6I3 (Derde peildatum-arrest). 
de mogelijkheid heeft ontnomen om zekerheid te verschaffen omtrent hetgeen in die hypothetische situatie zou zijn geschied. ${ }^{89}$

In het arrest Van Sas/Interpolis ging het om de vraag of een 46 jaar oud slachtoffer van een auto-ongeluk, dat daardoor arbeidsongeschikt raakte, zonder ongeval tot haar 65 ste jaar haar beroep zou hebben uitgeoefend of dat zij ervoor zou hebben gekozen om eerder te stoppen. De Hoge Raad overweegt, kort gezegd, dat de rechter met het verlies van die keuzemogelijkheid weliswaar zo veel mogelijk in het voordeel van de benadeelde partij rekening kan houden, maar dat dit niet zo ver gaat dat steeds van die mogelijkheid moet worden uitgegaan, tenzij in de persoonlijke omstandigheden van het slachtoffer reden wordt gevonden het tegendeel aan te nemen.

\subsection{Reeds geleden schade: ontwikkelingen tijdens de interim-periode}

56. Een van de consequenties van de vaststelling van voortdurende schade vanuit een ex post-perspectief - het gaat dan dus om schade die reeds is geleden - is dat het schadeverloop anders kan uitvallen dan men aanvankelijk had verwacht. Men kan te maken krijgen met 'causaliteit onderbrekende' gebeurtenissen maar ook met feiten en omstandigheden op grond waarvan de voor de vergelijkingsmaatstaf ingeschatte looplijnen gaandeweg slechts moeten worden bijgesteld. Het eerste ziet op het voortbestaan van de schade: bestaat er nog wel een verschil tussen de (vermogens)situatie met en zonder schadeveroorzakende gebeurtenis? Het tweede ziet meer op de schadeomvang: hoe groot is het verschil tussen de (vermogens-) situatie met en zonder schadefeit?

\section{Causaliteitsdoorbreking}

57. Bij de zogenoemde causaliteitsdoorbreking gaat het om de situatie waarin, voordat het te verwachten gevolg van een aansprakelijkheidscheppende gebeurtenis zich daadwerkelijk heeft verwezenlijkt, zich een andere gebeurtenis voordoet die reeds direct tot hetzelfde gevolg leidt. Hierdoor wordt dan de verwachte verwezenlijking van de schade door de eerdere gebeurtenis voorkomen. ${ }^{\circ}$ Het aanvankelijk veronderstelde condicio sine qua non-verband wordt daarmee 'doorbroken', en de aansprakelijke dus in beginsel bevrijd. Het betreft hier de zogenoemde 'samenlopende oorzaken', die zich successievelijk voordoen: men gaat er daarbij van uit dat dezelfde (vermogens)situatie ook na de tweede, later opkomende oorzaak zou zijn ontstaan..$^{91}$ Men spreekt ook wel van 'dubbele veroorzaking'. ${ }^{92}$

Een dergelijk probleem speelde in het arrest Kennis/Budel. ${ }^{93}$ Kennis kocht in I980 een terrein van Bossers, waarmee hij gevolg gaf aan de wens van de gemeente Budel om zijn transportbedrijf, dat in het centrum gevestigd was, te verplaatsen. Hij ging over tot die koop na toezeggingen van de toenmalige wethouder grondzaken, maar kort daarna

89 HR I5 mei I998, NJ I998/624 (Vehof-Vasters/Helvetia), r.o. 3·5.2.

9o Klaassen, Schadevergoeding: algemeen, deel 2 (Mon. BW nr. B35) 2007/28.

9I Vgl. C.J.H. Brunner in zijn noot onder HR 2 februari I990, NJ I99I/292 (Staat/Vermaat).

92 Vgl. Boonekamp, in: GS Schadevergoeding, art. 6:98 BW, aant. A. (online, laatst bijgewerkt 20 februari 20I6). Zie over deze problematiek uitvoerig L.C. Roelofs, 'Het schademoment als uitgangspunt voor hypothetische en "onderbroken” causaliteit', NTBR 2008-9, p. 382-39I. 
komt diens opvolger op die toezeggingen terug, en stelt voorwaarden aan het verkrijgen van vergunningen waardoor de met Bossers gesloten overeenkomst voor Kennis minder aantrekkelijk bleek. Kennis vordert vergoeding van de 'bedrijfsschade' die hij lijdt doordat de gemeente de aan hem gedane toezeggingen niet is nagekomen.

De zaak wordt gecompliceerd wanneer in 1985 blijkt dat de Kroon in 1985 de voor de realisering van het bedrijf van Kennis nodige Hinderwetvergunning heeft geweigerd. De gemeente stelt zich op grond van deze (latere) omstandigheid op het standpunt dat de realisering van het bedrijf van Kennis op het betreffende terrein toch niet mogelijk zou zijn geweest. Dat houdt evenwel geen stand bij de Hoge Raad: 'Indien de gemeente onrechtmatig heeft gehandeld door de voormelde toezeggingen niet na te komen en Kennis als gevolg daarvan zijn bedrijf niet op de aangegeven plaats heeft kunnen vestigen en daardoor schade heeft geleden, wordt het oorzakelijk verband tussen dat onrechtmatig handelen en die schade niet verbroken doordat zich naderhand feiten hebben voorgedaan die eveneens tot een zodanige schade zouden hebben geleid, indien de gemeente deze toezeggingen wel gestand zou hebben gedaan. Daarbij is zonder belang of (...) bij een zodanige gestanddoening de gang van zaken ter zake van de uiteindelijk geweigerde hinderwetvergunning op overeenkomstige wijze zou zijn verlopen en tot eenzelfde uitkomst zou hebben geleid als nu het geval geweest is.'

Men zou eenvoudigweg kunnen zeggen: de eenmaal veroorzaakte schade is nu eenmaal veroorzaakt en de aansprakelijkheid daarvoor is gevestigd, en latere gebeurtenissen kunnen daarin geen verandering meer brengen. ${ }^{94}$

58. Naar algemeen wordt aangenomen dient een uitzondering te worden gemaakt voor schade die over een langere tijdsperiode 'groeit', zoals bij schade wegens verlies van winst- of verdiencapaciteit. In zulke gevallen zouden later opkomende gebeurtenissen die tot datzelfde verlies zouden hebben geleid, wél tot een zekere 'doorbreking' van de causale keten leiden.

Een treffend en bekend voorbeeld hiervan biedt het arrest Staat/Vermaat. ${ }^{95}$ Van Ruijven is door schuld van Vermaat arbeidsongeschikt geworden, maar Vermaat meent - in het kader van een door de Staat ingestelde regresactie - vanaf een zeker moment niet langer tot vergoeding van de daaruit voortvloeiende vermogensschade te zijn gehouden, nu Van Ruijven inmiddels een hartinfarct had gekregen dat hem - het eerste ongeval weggedacht - evengoed arbeidsongeschikt zou hebben gemaakt. De Hoge Raad ziet met Vermaat inderdaad geen reden om de inkomensschade vanaf dat tijdstip nog toe te rekenen aan de eerste oorzaak, waarvoor Vermaat aansprakelijk is: 'Het hof heeft echter miskend dat wanneer bij zulk een voortdurende inkomensschade blijkt dat de gelaedeerde, ook indien het ongeval niet had plaatsgevonden, op enigerlei tijdstip geheel of gedeeltelijk arbeidsongeschikt zou zijn geworden ten gevolge van een omstandigheid die voor zijn risico komt - zoals het geval kan zijn bij een door de gelaedeerde opgelopen ziekte, wanneer die geen verband houdt met het door het ongeval veroor-

94 Vgl. A-G Huydecoper in zijn conclusie voor NJ 2002/576 m.nt. J.B.M. Vranken (Gemeente Leeuwarden/Los).

95 HR 2 februari 1990, NJ 1991/292 m.nt. C.J.H. Brunner (Staat/Vermaat). Een hiermee vergelijkbaar geval (eveneens een hartinfarct) doet zich voor in Rb. Amsterdam 2I mei 20I4, JA 20I4/93 m.nt. M.S.E. van Beurden. 
zaakte letsel - er geen reden is om de inkomensschade vanaf het tijdstip dat de voor eigen risico komende arbeidsongeschiktheid zou zijn ingetreden, nog toe te rekenen aan degeen die voor het ongeval aansprakelijk is. (...) De verplichting tot vergoeding van door een ongeval veroorzaakte schade gaat niet zover dat degeen die voor die schade aansprakelijk is, de gelaedeerde ook moet behoeden voor schade die zonder dat ongeval voor diens eigen risico zou komen. ${ }^{96}$

59. Uit de overwegingen van de Hoge Raad volgt dat de latere gebeurtenis of handeling voor eigen risico van de benadeelde moet komen, wil het een reden vormen om de schade niet langer toe te rekenen aan de eerste oorzaak. Belangrijk is om hier in te zien dat door (voldoende) tijdsverloop pas kon komen 'vast te staan' dat de benadeelde ook in de hypothetische situatie zonder ongeval arbeidsongeschikt zou zijn geworden, en wel vanaf het moment van de hartaanval. ${ }^{97}$

In het arrest Gemeente Leeuwarden/Los speelde een vergelijkbare vraag, en komt de Hoge Raad tot enige nadere uitwerking hiervan. Het ging in die zaak om een door de huurder (Los) van een horecaruimte ingestelde vordering tot vergoeding van schade wegens derving van winst over de periode 1994-2004 wegens het opzeggen van de huurovereenkomst wegens voorgenomen eigen gebruik, dat vervolgens uitbleef. Enkele dagen voor het uitbrengen van de dagvaarding in 1996 gaat de gehuurde ruimte geheel teniet door brand. De vraag rijst in hoeverre deze omstandigheid moet worden meegewogen bij het bepalen van de door Los geleden schade. De gemeente stelt zich op het standpunt dat de huurovereenkomst door het tenietgaan van het gehuurde niet pas in 2004 zou zijn geeindigd maar - naar achteraf blijkt - reeds in 1996. De Hoge Raad overweegt als volgt: 'Indien zich na een schadeveroorzakende gebeurtenis waarvoor iemand aansprakelijk is jegens de benadeelde, een latere gebeurtenis voordoet die dezelfde schade zou hebben veroorzaakt als die schade niet reeds was ontstaan, doet dat niet af aan de reeds gevestigde verplichting tot schadevergoeding van de voor de eerste gebeurtenis aansprakelijke. Behalve in gevallen waarin de latere gebeurtenis voor risico van de benadeelde komt (...) bestaat er geen grond daarover anders te oordelen indien het gaat om voortdurende schade (...). Bij de vaststelling van de omvang van de schade moet een vergelijking worden gemaakt met de toestand zoals die zonder de huuropzegging zou zijn geweest. In die (hypothetische) situatie, waarin de huurverhouding ten tijde van de brand nog zou hebben bestaan, zou het tenietgaan van het gehuurde in de contractuele verhouding tussen partijen in die zin voor rekening van Los zijn gekomen dat de Gemeente dientengevolge (...) zou zijn bevrijd van haar verplichting het huurobject aan hem ter beschikking te stellen. Dat op zichzelf rechtvaardigt echter niet ook in de hier na het einde van de huur door de opzegging van de Gemeente ontstane situatie het tenietgaan door brand van het vroeger door Los gehuurde, waarover hij geen enkele zeggenschap meer had, aan hem toe te rekenen.'

Ten aanzien van de vraag of sprake is van een omstandigheid die voor risico van Los komt, overweegt de Hoge Raad: 'dat het tenietgaan van het eerder door Los gehuurde door de brand van 25/26 november 1996 niet afdoet aan de aansprakelijkheid van de Gemeente jegens Los voor de gehele schade over de periode 1994-2000. Daaraan staat niet in de weg dat de brand zich ten tijde van de vaststelling van de omvang van

96 HR 2 februari I990, NJ I99I/292 m.nt. C.J.H. Brunner (Staat/Vermaat), r.o. 3.3.

97 Vgl. A.J. Akkermans, 'Causaliteit bij letselschade en medische expertise', TVP 2003-4, p. 100. 
de schade reeds had voorgedaan, zodat geen sprake was van afweging van goede en kwade kansen in de zin van art. 6:105 BW, maar van een zekere gebeurtenis, waarmee bij de (...) vergelijking met het oog op de schadeberekening in beginsel rekening moet worden gehouden.'

6o. In Staat/Vermaat werd een vergelijking gemaakt met de hypothetische situatie waarin het ongeval niet had plaatsgevonden; in Gemeente Leeuwarden/Los gaat het om een vergelijking met de hypothetische situatie zonder ontruiming en huuropzegging. ${ }^{8}$ Bepalend is in dit soort kwesties of de latere gebeurtenis - het hartinfarct respectievelijk de brand - voor risico van de benadeelde komt. In essentie draait het hier om de vraag of brandstichting door een derde hetzelfde is als een hartinfarct door een eigen 'gebrek' van de benadeelde. ${ }^{99}$ De overwegingen van de Hoge Raad in Gemeente Leeuwarden/Los maken duidelijk dat 'voor risico komen van' meer kan omvatten dan alleen persoonlijke omstandigheden, zoals aan de orde waren in Staat/Vermaat. ${ }^{100}$ Maar waar de grens nu precies moet worden getrokken, en hoe het criterium 'voor risico van de benadeelde' nu precies moet worden begrepen, is onduidelijk. Op het eerste oog lijkt de beslissing om wel of geen causaliteitsdoorbreking aan te nemen te zien op de schadevraag en niet op de vergoedingsvraag, maar de bewoording 'voor risico van de benadeelde' kan evengoed worden opgevat als een normatieve toerekeningsvraag.

Een en ander wordt door de Hoge Raad nog eens bevestigd in het VPV-arrest, waarin ook de vraag speelt of een latere gebeurtenis voor risico van de benadeelde komt. ${ }^{\text {Ior }}$ In deze zaak worden De Nederlandsche Bank (DNB) en de Autoriteit Financiële Markten (AFM) aansprakelijk gesteld door twee bestuurders (V. en P.) van vermogensbeheerder Veer Palthe Voûte (VPV). Vermoed werd - kort gezegd - dat zij zich schuldig hadden gemaakt aan misbruik van voorwetenschap, en in verband daarmee werden zij in 2003 ontslagen. Directe aanleiding tot het ontslag was een 'aanwijzing' van DNB en AFM, nadat DNB en AFM een strafrechtelijke aangifte ter zake van het vermoede misbruik hadden gedaan, maar vóórdat deze aangifte tot een strafrechtelijke uitspraak had geleid. Tegen de aanwijzingen van DNB en AFM hebben de bestuurders bezwaar gemaakt. Tegen de daarop genomen afwijzende besluiten zijn zij in beroep gegaan bij het College van Beroep voor het bedrijfsleven ( $\mathrm{CBb}$ ), dat deze besluiten vernietigde, met herroeping van de aanwijzingen, omdat DNB en AFM ten aanzien van de aanvangsdatum van het door hen vermoede misbruik van voorwetenschap geen afdoende motivering hadden gegeven. De bestuurders vorderen vergoeding van gederfd salaris en gederfde bonussen (en een vergoeding wegens immateriële schade) van DNB en AFM. Waar de aansprakelijkheid van DNB en AFM jegens de bestuurders wordt aangenomen, rijst de vraag wat de betekenis is van de (later alsnog) tegen hen gewezen strafvonnissen voor het bestaan en de omvang van hun schade. De Hoge Raad overweegt: 'Indien zich na een schadeveroorzakende gebeurtenis waarvoor iemand aansprakelijk is jegens de benadeelde (hier: de onrechtmatige aanwijzingsbesluiten van I4 april 2003 waarvoor

98 De aansprakelijkheidsgrond en de door de eiser in dit verband betrokken stellingen bepalen dus, zoals eerder aangegeven, het perspectief bij de vaststelling van de omvang van de schade.

99 W.H. van Boom, 'Meervoudige oorzaken, hoofdelijke aansprakelijkheid en toerekening naar redelijkheid', in: A. Hammerstein e.a., Causaliteit, Den Haag: Vermande 2003, p. 89-I03.

Ioo Vgl. Vranken in zijn NJ-noot onder HR 7 december 200I, NJ 2002/576 (Gemeente Leeuwarden/Los).

IOI HR 23 december 20II, NJ 20I2, 377 m.nt. Van Schilfgaarde (VPV). 
DNB en AFM aansprakelijk zijn jegens V. en P.) een latere gebeurtenis voordoet die dezelfde schade zou hebben veroorzaakt als die schade niet reeds was ontstaan, doet dat niet af aan de reeds gevestigde verplichting tot schadevergoeding van de voor de eerste gebeurtenis aansprakelijke persoon, behalve in gevallen waarin het gaat om voortdurende schade en de latere gebeurtenis voor risico van de benadeelde komt (...). Het hof heeft kennelijk, en niet onbegrijpelijk, geoordeeld dat de strafvonnissen aangemerkt moeten worden als een dergelijke latere gebeurtenis die voor risico van V. onderscheidenlijk P. komt, en dat die strafvonnissen voor hen tot ontslag en derhalve vanaf dat moment tot dezelfde, voortdurende, schade zouden hebben geleid. Dat oordeel geeft geen blijk van een onjuiste rechtsopvatting. ${ }^{\text {'02 }}$

In een recent arrest benadrukt de Hoge Raad nog eens dat de mogelijkheid van een causaliteit onderbrekende gebeurtenis onvoldoende is om te concluderen dat er geen schade (meer) wordt geleden. Het ging om een zaak waarin een ondernemer van de Gemeente Hengelo vergoeding vordert voor de schade die hij zou hebben geleden doordat de voor de verplaatsing van zijn stoeterij vereiste milieuvergunning tot viermaal toe wordt vernietigd. Het draait in cassatie onder meer om de vraag of de gebreken in een vergunning wel hebben geleid tot schade wegens de niet of vertraagde herhuisvesting van de stoeterij. De Gemeente verweert zich namelijk door te stellen dat deze gebrekkige vergunning niet tot schade heeft geleid, of er althans geen causaal verband bestaat met de schade, nu zij ook de mogelijkheid had om de betreffende vergunning te weigeren op grond van het ontbreken van het daarvoor vereiste 'ammoniakreductieplan'. Dit berust volgens de Hoge Raad echter op een onjuiste rechtsopvatting: 'Niet beslissend is (...) of het College de vergunning rechtmatig had kunnen weigeren, maar - zoals het hof tot maatstaf heeft genomen - welk besluit het zou hebben genomen indien het wel overeenkomstig de wet zou hebben beslist.' ${ }^{103}$ Dat onderstreept dat het bij het bepalen van de hypothetische situatie zonder aansprakelijkheidscheppende gebeurtenis gaat om de concrete invulling van het hypothetisch scenario. Het veronderstelde verloop der gebeurtenissen is bepalend: het gaat niet om de vraag wat er had kunnen gebeuren, maar om de vraag wat er zou zijn gebeurd. Hiermee verwerpt de Hoge Raad - in lijn met zijn eerdere rechtspraak - de aan de leer Demogue-Besier ontleende gedachte dat het causaal verband tussen de schade en de aansprakelijkheidscheppende gebeurtenis ontbreekt, indien de schade veronderstellenderwijze ook had kunnen worden veroorzaakt door gedragingen die niet in strijd met enige norm geweest zouden zijn of door omstandigheden waarvoor niet iemand anders aansprakelijk gesteld kan worden. ${ }^{\text {104 }}$

6r. Men kan zich afvragen of het wel steeds voor de hand ligt om uit te gaan van 'causaliteitsdoorbreking' op basis van later opkomende feiten en omstandigheden. De redenering uit het arrest Staat/Vermaat leidt ertoe dat er bij de schadevaststelling van wordt uitgegaan dat Van Ruijven, ook als hij in 1976 niet arbeidsongeschikt was geraakt bij een verkeersongeval, evengoed in 1983 (ongeveer 7 jaar later) een hartinfarct zou hebben gehad en definitief arbeidsongeschikt zou zijn geworden. Men gaat er dan dus van uit dat het betreffende slachtoffer hoe dan ook gepredisponeerd/gedetermineerd was om op exact datzelfde ogenblik een hartinfarct

IO2 HR 23 december 20II, NJ 20I2/377 m.nt. Van Schilfgaarde (VPV), r.o. 4.I.3.

I03 HR 3 juni 20I6, JA 20I6/I23 m.nt. J.L. Brens, r.o. 3·5·4.

Io4 Vgl. Boonekamp, in: GS Schadevergoeding, art. 6:98 BW, aant. I.5.2 (online, laatst bijgewerkt 20 februari 2016). 
te krijgen, ook in de situatie waarin hij nog jaren werkzaam zou zijn geweest als ambtenaar. Men stelt de hypothetische situatie wat betreft het optreden van het hartinfarct gelijk met de feitelijke situatie. ${ }^{105}$ Dit is in zoverre wijsheid achteraf (perfect hindsight) dat dit van tevoren moeilijk zo concreet kon worden voorzien: dergelijke 'discontinue ontwikkelingen' laten zich nu eenmaal lastig voorspellen.

62. De hierboven beschreven casus worden vooral geframed als een probleem van de zogenoemde 'onderbroken causaliteit', maar zij illustreren ook bij uitstek welke belangen er met het verloop van tijd gemoeid kunnen zijn bij hantering van een ex post-benadering. Neem de casus in Staat/Vermaat. Zou het nog vóórdat Van Ruijven een hartaanval overkwam tot een definitieve schadevaststelling zijn gekomen, dan stellen wij ons zo voor dat die (onvoorziene) hartaanval onmogelijk als het einde van de schadeperiode kon worden ingeschat, met alle gevolgen van dien voor de hoogte van de schadevergoeding indien die in een bedrag ineens zou zijn uitgekeerd. Wanneer bij de schadevaststelling dergelijke aannames over het einde van de schadeperiode worden gehanteerd dienen deze immers toereikend te worden gemotiveerd.

Zo blijkt eens te meer uit het recente arrest M./Vossen Laboratories Int. B.V. In die zaak oordeelde het hof dat de schade die het slachtoffer lijdt wegens blijvende arbeidsongeschikt op een zeker moment zou ophouden te bestaan omdat het slachtoffer op enig ander moment in zijn leven, en in ieder geval uiterlijk omstreeks 55-jarige leeftijd, op een zodanige wijze op een al dan niet ernstig 'life-event' zou reageren dat hij daardoor evengoed arbeidsongeschikt zou zijn geraakt. Het hof leidde dit af, kort gezegd, uit het feit dat het slachtoffer op relatief gering letsel reageerde met een ernstige psychische reactie (toe te schrijven aan zijn persoonlijke predispositie). De Hoge Raad casseerde het arrest van het hof wegens het ontbreken van een toereikende motivering waarom een dergelijke psychische reactie in zijn algemeenheid aannemelijk maakt dat het slachtoffer vanaf een zeker moment, als gevolg van andere gebeurtenissen, niet meer in staat zou zijn geweest zijn loonvormende arbeid te verrichten. ${ }^{106}$

63. Doet zich gedurende de interim-periode een gebeurtenis voor die reeds direct tot dezelfde voortdurende schade leidt (zoals het hartinfarct van Van Ruijven) maar die in het geheel niet voorzienbaar was, dan houdt de schade niettemin op te bestaan (mits de gebeurtenis 'voor risico van de benadeelde' komt). Dat betekent dat de bij het schadevergoedingsdebat betrokken partijen dus wel steeds de klok in de gaten moeten houden, en dat tijd zowel vriend als vijand kan blijken. Doet zich in de periode tussen aansprakelijkheidscheppende gebeurtenis en schadevaststelling niet een dergelijke 'schadedrukkende' gebeurtenis voor, dan is het voor de schuldenaar bepaald lastiger om af te dingen op de toekomstverwachtingen van de benadeelde bij gebreke van concrete aanknopingspunten.

I05 Vgl. A.J. Akkermans, 'Causaliteit bij letselschade en medische expertise', TVP 2003-4, p. Ioo.

Io6 HR 27 november 20I5, NJ 20I6/138 m.nt. S.D. Lindenbergh (M./Vossen Laboratories Int. B.V.), r.o. $3 \cdot 3 \cdot 2$. 
64. Een wat andere categorie betreft feiten en omstandigheden op grond waarvan de voor de vergelijkingsmaatstaf aanvankelijk ingeschatte looplijnen gaandeweg moeten worden bijgesteld. Het gaat dan niet zozeer om de doorbreking van de causaliteit, maar om gaandeweg opkomende feiten en omstandigheden die de omvang van de schade nader bepalen. Latere ontwikkelingen kunnen bijvoorbeeld nader inzichtelijk maken hoe de situatie zonder aansprakelijkheidscheppende gebeurtenis zou zijn geweest (en de aanvankelijk geldende verwachtingen zowel naar boven als naar beneden doen bijstellen). Zulke ontwikkelingen hebben dus, via de vergelijking tussen de situatie met en zonder aansprakelijkheidscheppende gebeurtenis, een verhogend of verlagend effect op de schadeomvang.

Een voorbeeld ter illustratie biedt de uitspraak van de Rechtbank Oost-Brabant in een zaak waarin het ging om een stukadoor die na een hem in 2004 overkomen ongeval jarenlang moest procederen voor schadevergoeding, onder meer wegens inkomensschade. De rechtbank overweegt ten aanzien van de omvang van de inkomensschade: 'Inmiddels is al meerdere jaren sprake van een economische crisis, waarmee rekening moet worden gehouden bij het bepalen van de redelijke verwachtingen omtrent de ontwikkelingen die zonder ongeval zouden hebben plaatsgevonden. Ook als hem het ongeval niet was overkomen, had deze crisis vermoedelijk gevolgen gehad voor de (inkomens)situatie (...). Het is immers een feit van algemene bekendheid dat de bouwsector zwaar te lijden heeft onder de crisis en dat vanaf 2009 tot heden sprake is van een fors krimpende werkgelegenheid bij stukadoors, zodat het maar de vraag is of [eiser] zijn baan had weten te behouden.' ${ }^{107}$

Het gaat hier om een ongeval uit 2004, maar de arbeidsvermogensschade wordt vastgesteld naar de inzichten die men in 2013 - dus bijna tien jaar later - had, met inachtneming van de dan geldende verwachtingen ten aanzien van de economie en de werkgelegenheid. Niet is uitgesloten dat dit slachtoffer bij een meer voortvarende schadeafwikkeling, laten we zeggen met een einduitspraak in 2007, een hogere schadevergoeding zou toekomen. Het omgekeerde kan natuurlijk ook spelen, wanneer de schade wordt vastgesteld in een periode van hoogconjunctuur. ${ }^{108}$

Het gaat net als bij 'causaliteitsdoorbreking' om later opkomende omstandigheden die nader invulling geven aan het schadeverloop, maar hier gaat het meer specifiek om gebeurtenissen die wel nader inzicht geven in de positie waarin de benadeelde zonder de aansprakelijkheidscheppende gebeurtenis zou hebben verkeerd.

I07 Rb. Oost-Brabant 3 juli 2013, JA 2013/179, r.o. 2.36.

Io8 Vgl. S.D. Lindenbergh, Van Smart naar Geld. Ervaringen van tien slachtoffers van letselschade met hun schadevergoedingsprocedure tot en met de Hoge Raad, Deventer: Kluwer 20I3, p. III-II2, waar de interviews ook laten zien dat het recht zelf zich gedurende de interim-periode nog kan ontwikkelen in het voor- of nadeel van partijen. 


\subsection{Het begroten van voortdurende schade in een som ineens}

Kapitalisatie van voortdurende schade

65. Waar de praktijk er doorgaans de voorkeur aan lijkt te geven om voortdurende schade te begroten op een bedrag ineens, moet voor de schadebegroting een zekere vertaalslag worden gemaakt van wat zich in werkelijkheid over een periode uitstrekt naar één begrotingsmoment. Dit gebeurt door te kapitaliseren. Kapitaliseren kan worden omschreven als 'de waarde van iets berekenen naar de gemiddelde baten en lasten', en is een methode om een in de toekomst terugkerende schade in één keer in zijn totaal vast te stellen. ${ }^{109}$ Zodra het schadeverloop is vastgesteld, zet men de bedragen die gespreid over de schadeperiode zouden moeten worden uitgekeerd om de opkomende negatieve vermogensverschillen op te heffen om naar de kapitaalwaarde daarvan op het tot uitgangspunt genomen moment, ook wel aangeduid als de peildatum of kapitalisatiedatum. In de kern draait het bij kapitalisatie om de vraag om welk bedrag het gaat, over welke periode gekapitaliseerd moet worden en tegen welke rentevoet. Bij kapitalisatie spelen tijdsaspecten dus een centrale rol. Het gaat kort gezegd om de tijdspanne tussen het moment waarop de schadevergoeding wordt uitgekeerd en het tijdstip waarop het uitgekeerde bedrag door de benadeelde zal (moeten) worden aangewend om een zich dan realiserend tekort te compenseren. ${ }^{\text {IIO }}$ Dat geschiedt mogelijk pas in een verre toekomst.

66. Men neemt bij het kapitaliseren in ogenschouw wat de (toekomstige) gevolgen zijn van de uitkering van de vergoeding (de benadeelde beschikt immers eerder over het bedrag aan schadevergoeding dan het moment waarop de schade 'valt'). Zo moet er rekening worden gehouden met de inkomsten die de benadeelde door belegging van de hem toegekende som kan verwerven. ${ }^{\text {III }}$ Ook hier wordt overigens een abstractie toegepast, nu er bij deze stap wordt uitgegaan van voordelen wegens belegging van de toegekende som, ongeacht de vraag of de benadeelde het bedrag daadwerkelijk daartoe (met enig succes) aanwendt. Bovendien betreft de renteopbrengst die over de vergoeding kan worden gerealiseerd - en daarom op het bedrag in mindering wordt gebracht - niet veel meer dan een inschatting van het toekomstige rendement, die mede van het beleggingsklimaat afhankelijk is. Deze verrekening van (potentieel) rendement vormt als het ware het spiegelbeeld van de situatie waarin een vordering gedurende een bepaalde periode weliswaar opeisbaar is geworden maar niet wordt voldaan, en daarom met wettelijke rente wordt verhoogd. ${ }^{112}$ Waar die wettelijke rente ziet op de vertragingsschade ziet de rendementsverdiscontering dus op het 'voordeel wegens vooruitbetaling'. Het eerste is wettelijk gefixeerd en wordt geheel abstract vastgesteld (artikel 6:II9 BW); het laatste is niet wettelijk vastgelegd en moet uiteindelijk door de rechter worden bepaald, waarbij het aankomt op de redelijke verwachtingen. Naast de te verrekenen mogelijkheid om rendement te verwerven speelt ook de inflatie een rol,

Io9 Zie H.J.M. van Mierlo \& B.P.M. van Ravels, 'Kapitalisatie en nadeelcompensatie', O\&A 20II-4, p. I40.

IIo Vgl. R.Ph. Elzas, 'Toekomstige personenschade', Het Verzekerings-Archief 2015-2, p. 67.

III Zie A.T. Bolt, GS Schadevergoeding, art. 6:I05 BW, aant. 7.I.

II2 R.Ph. Elzas, 'Toekomstige personenschade', Het Verzekerings-Archief 2015-2, p. 73. 
oftewel de te verwachten waardevermindering van geld. Door een inflatiecorrectie toe te passen, wordt rekenschap gegeven van de verwachting dat in het algemeen prijzen zullen stijgen en dat de 'interne waarde' van de schadevergoeding met de tijd zal afnemen. Als een vergoeding reeds nu wordt uitgekeerd met het oog op het compenseren van een tekort in de toekomst, dan moet die inflatie dus worden verdisconteerd.

67. Het verschil tussen het percentage voor de renteopbrengst en het percentage voor de inflatiecorrectie wordt ook wel de 'rekenrente' genoemd, hoewel het niet een vastomlijnd begrip is. ${ }^{113}$ De rekenrente staat tegenwoordig ter discussie, waar vraagtekens worden geplaatst bij het hanteren van een vast rendementspercentage in een tijd waarin men niet langer gelooft in toekomstige constante economische groei. ${ }^{\text {II }}$ Een hogere rendementsverdiscontering dan wat daadwerkelijk nog aan rendement kan worden gegenereerd valt immers moeilijk te verantwoorden: het zou immers tot gevolg hebben dat het slachtoffer niet de gehele schade vergoed krijgt. In de Nederlandse rechtspraak lijkt men dan ook vatbaar voor het omlaag bijstellen van de rekenrente. ${ }^{115}$

Waar het gaat om rekenrente over een lange periode, ligt het voor de hand om deze (pas) bij te stellen als over een lange periode een bepaald gemiddelde te verwachten valt, zoals het Hof Arnhem-Leeuwarden overweegt:

'Het hof is zich er van bewust dat het enkele feit dat een rekenrente tijdelijk lager is nog niet rechtvaardigt dat voor de eerste periode een lagere rekenrente wordt gehanteerd en voor de latere periode een hogere rekenrente. Het gaat immers om een gemiddeld percentage over een langere periode. $\mathrm{Nu}$ de actuele rekenrente zozeer verschilt van de overigens te hanteren rekenrente en geen sprake is van een plotselinge daling maar van een langjarige ontwikkeling acht het hof het hanteren van een rekenrente voor de periode tot I januari 2018 echter alleszins gerechtvaardigd. Het neemt daarbij in aanmerking dat gelet op de ontwikkeling van de laatste jaren het niet in de lijn der verwachtingen ligt dat binnen afzienbare termijn een rekenrente van meer dan $3 \%$ zou moeten worden gehanteerd. ${ }^{\text {II6 }}$

68. In combinatie met de looptijd van de schade kan de kapitalisatiefactor worden bepaald. Bij personenschadezaken is niet ongebruikelijk hierin ook de sterftekans, die samenhangt met de leeftijd van het slachtoffer, mee te rekenen: de vermogensschade (bijvoorbeeld bestaande in misgelopen inkomsten wegens verlies van arbeidsvermogen of in nog te maken kosten voor zorg) 'eindigt' immers feitelijk op het moment dat de gewonde overlijdt. ${ }^{117}$ Toch is dat niet geheel vanzelfsprekend: weliswaar geeft de sterftekans uitdrukking aan de reële onzekerheid

II3 Soms zit de inflatiecorrectie juist inbegrepen in de 'rekenrente'.

II4 Zie voor de discussie hieromtrent onder meer D.J. ten Boom, 'De X-factor in de toekomstschade: mysterieus of meetbaar?', TVP 2006-3, p. 76-8I, J. Tiemersma, 'Rekenrente', VR 2013/76 met reactie van J. Laumen in VR 2013/128 en R.M.J.T. van Dort, 'Fiscale opfrisser, een opmerkelijk vonnis en de rekenrente naar minder dan 2\%, TVP 20I4-I, p. 8-I7.

II5 Zie bijv. Rb. Midden-Nederland I7 september 20I4, JA 20I4/I46 m.nt. C.C. Janssen en J.C. van den Dries, Rb. Noord-Holland 8 oktober 20I4, NJF 2013/39I.

II6 Hof Arnhem-Leeuwarden 3I maart 20I5, JA 20I5/77 m.nt. J. Laumen-de Valk, r.o. 7.I3.

II7 Bolt, in: GS Schadevergoeding, art. 6:107 BW, aant. 2.I2.5. 
die heerst waar het inschattingen ten aanzien van de toekomst betreft, maar voor de vaststelling van schade wordt niettemin doorgaans (na afweging van goede en kwade kansen) uitgegaan van een bepaald feitelijk verloop, dus óók ten aanzien van toekomstige gebeurtenissen. De vraag die rijst, is wanneer men eigenlijk nog een 'feitelijk' toekomstscenario en hypothetisch toekomstscenario wil 'invullen' en wanneer men overgaat tot uitdrukkingen in kansen of het toepassen van onzekerheidscorrecties. ${ }^{\text {Ir8 }}$ Daarbij kan men zich afvragen of bij het toepassen van dergelijke gemiddelde sterftekansen geen verboden onderscheid wordt gemaakt op grond van geslacht, wanneer men bijvoorbeeld algemene onderlinge verschillen in levensverwachting tussen mannen en vrouwen doorrekent in de hoogte van de vergoeding van hun toekomstige schade. ${ }^{\text {II }}$

\section{Kapitalisatie naar een peildatum in het verleden}

69. Hoewel het voor de hand ligt om als peildatum voor de kapitalisatie van toekomstige schade te kiezen de datum die zo dicht mogelijk ligt bij de datum van afwikkeling of de datum van de uitspraak van de rechter - men spreekt immers van 'toekomstige schade' waar het gaat om schade gelegen in tijd die nog komen moet - staat het de rechter volgens vaste rechtspraak (maar niet onomstreden) vrij om toekomstige schade te kapitaliseren in een bedrag ineens naar een peildatum die geruime tijd voor zijn uitspraak ligt. Het gaat hier niet zozeer om het probleem dat de peildatum niet exact op de datum van de rechterlijke beslissing over de vergoeding van toekomstige schade valt: het lijkt immers onhaalbaar dat steeds op de dag van de beslissing een geheel actueel overzicht van de schade, gesplitst in reeds geleden schade en nog werkelijke toekomstige schade, op tafel ligt. ${ }^{120} \mathrm{Het}$ gaat om situaties waarin de peildatum in een relatief ver verleden wordt gesteld, en zelfs kan worden gesteld op de datum van de aansprakelijkheidscheppende gebeurtenis.

In de zogenoemde Peildatum-arresten - alle drie gewezen in personenschadezaken staat de Hoge Raad kapitalisatie van reeds verschenen schade (dus met een peildatum in het verleden) toe. ${ }^{\mathrm{I} 2 \mathrm{~S}}$ Steeds lijkt de inzet de aanspraak op wettelijke rente over het bedrag ineens per moment van ontstaan van de schade. De Hoge Raad overweegt in het Eerste peildatum-arrest: 'De wijze van begroting bepaalt immers op welk tijdstip de betreffende schade geacht moet worden te zijn geleden. In de onderhavige zaak is in dit verband in het bijzonder van belang dat inkomensschade zowel begroot kan worden op de concrete bedragen die periodiek aan inkomen zouden zijn verkregen wanneer het ongeval niet zou hebben plaatsgevonden, en ter zake waarvan de vervangende schadevergoeding dan ook periodiek verschuldigd wordt, als op een gekapitaliseerd bedrag ineens ter zake van toekomstige schade, die dan geacht moet worden op de bij deze kapitalisering tot uitgangspunt genomen peildatum te zijn geleden. Het is niet bij

II8 Enkele overwegingen worden recentelijk aan deze problematiek gewijd door Schreuder in haar noot onder HR 27 november 2015, JA 20I6/I4 m.nt. A.I. Schreuder.

II Zie hierover onder meer E.S. Engelhard, M.R. Hebly \& S.D. Lindenbergh, 'Gelijkheidsperikelen in het personenschaderecht', NTBR 2015/39.

I20 Vgl. A-G Wuisman onder punt 2.7 van zijn conclusie voor HR 30 november 2007, RvdW 2007/I025.

I2I HR I7 oktober 1997, NJ I998/508 m.nt. JBMV, HR II juli 2003, NJ 2003/603 en HR 30 november 2007, RvdW 2007, I025. 
voorbaat uitgesloten dat als peildatum de dag van het ongeval mag worden gekozen, in het bijzonder wanneer terstond vaststaat dat het slachtoffer door het ongeval blijvend arbeidsongeschikt is geworden. ${ }^{\mathrm{r} 22}$

In het Tweede peildatum-arrest ging het om de vraag of voor de berekening van de toekomstschade de datum van het ongeval als peildatum mocht worden gekozen, terwijl de schade was gekapitaliseerd met een latere peildatum. Opnieuw is de inzet de ingangsdatum van de wettelijke rente. De Hoge Raad overweegt met toelichting op het Eerste peildatum-arrest: 'In het arrest ligt besloten dat ook indien de rechter de schade begroot met als peildatum een later moment dan de dag van het ongeval, de vordering rentedragend wordt door de zojuist bedoelde aanmaning en mededeling, ongeacht of deze is uitgebracht voor de datum waartegen de rechter de schade kapitaliseert, of daarna.' ${ }^{123}$

Dan de vraag hoe, wanneer de peildatum in het verleden ligt, met na die peildatum opkomende of juist uitblijvende omstandigheden moet worden omgegaan. Ten aanzien van de vraag of de sterftekans kan worden verdisconteerd over de reeds verstreken periode indien het slachtoffer niet is komen te overlijden, overwoog de Hoge Raad in het Derde peildatum-arrest: 'Zoals (...) blijkt, heeft de rechter bij het begroten van schade de vrijheid om de geleden en te lijden schade te kapitaliseren in een bedrag ineens naar een peildatum die geruime tijd voor zijn uitspraak ligt. Ook bij een dergelijke wijze van begroting blijft evenwel uitgangspunt dat zoveel als redelijkerwijs mogelijk is de werkelijk geleden en te lijden schade behoort te worden begroot. Daarbij past niet dat de rechter slechts rekening mag houden met de op de peildatum bestaande verwachtingen over hetgeen de toekomst zou kunnen brengen. Het staat hem derhalve (...) vrij om bij kapitalisatie van blijvende en periodieke letselschade naar een lang voor zijn uitspraak gelegen peildatum, rekening ermee te houden dat het op de peildatum bestaande overlijdensrisico van de benadeelde zich tot dusver niet heeft gerealiseerd en daarom het overlijdensrisico over de voorbije jaren niet te verdisconteren. ${ }^{{ }^{1} 24}$

In dat arrest speelde ook nog de vraag hoe moet worden omgegaan met een tussentijdse wijziging van het belastingstelsel: 'Nu de rechter bij het bepalen van schadevergoeding zoveel als redelijkerwijs mogelijk is de werkelijk geleden en te lijden schade dient te begroten, had het hof zonder nadere motivering, die ontbreekt, niet mogen vasthouden aan een begroting van de belastingschade waarin wordt voorbijgegaan aan de ingrijpende wijziging van het belastingstelsel met ingang van 200I. ${ }^{125}$

70. Op de mogelijkheid van kapitalisatie naar een peildatum in het verleden is in de literatuur wel kritisch gereageerd. ${ }^{\mathrm{I} 26}$ Wanneer men als peildatum de datum van het aansprakelijkheidscheppende feit hanteert, is de consequentie daarvan dat ook schade die (inmiddels) reeds daadwerkelijk is geleden, wordt herleid tot de ongevalsdatum, daardoor wordt 'geacht op dat moment te zijn geleden' en dus vanaf dat moment ook rentedragend is. Een gevolg daarvan is dat de vergoedingsplicht

I22 HR I7 oktober I997, NJ I998/508 m.nt. JBMV (Eerste peildatum-arrest), r.o. 3.8.

I23 HR II juli 2003, NJ 2003/603 (Tweede peildatum-arrest), r.o. 3.5.

I24 HR 30 november 2007, RvdW 2007/I025 (Derde peildatum-arrest), r.o. 5·3.

I25 HR 30 november 2007, RvdW 2007/I025, r.0. 4.2.

I26 Zie onder meer C.J.M. Klaassen, Het moment van ontstaan van schade, preadvies Vereniging Burgerlijk Recht I998, p. 23, het commentaar van E. Wijtema op HR II juli 2003, NJ 2003/63 in TVP 2004-2, p. 6o-62 en W.J. Hengeveld \& H.Th. Vos, 'Wettelijke rente en kapitalisatie: HR 30 november 2007 RvdW 2007, I025 LJN BA4606', TVP 2008-I, p. 36-40. 
van de aansprakelijke aanzienlijk in omvang kan toenemen, waardoor deze een direct financieel belang heeft gekregen bij een zo snel mogelijke afdoening van de schade. ${ }^{127}$

7I. De vraag die dus ook in dit verband weer rijst, is hoe men moet omgaan met opkomende feiten en omstandigheden in de periode gelegen tussen het als peildatum gekozen tijdstip van de schadeveroorzakende gebeurtenis en het latere moment waarop de schadevergoeding wordt berekend. Wanneer men per peildatum een ex ante-schadeperspectief hanteert, dan mogen deze geen rol spelen: de schade wordt qua omvang immers naar het moment van de peildatum bepaald, dus naar de op dat moment heersende toekomstverwachtingen. De overwegingen van de Hoge Raad laten echter zien dat wanneer een peildatum (ruim) voor het tijdstip van de berekening van de schadevergoeding ligt, dit niet wegneemt dat de schade zo veel mogelijk 'concreet' (en dus ex post) moet worden vastgesteld, en dat dan dus niet heeft te gelden dat slechts rekening mag worden gehouden met de op de peildatum bestaande verwachtingen over wat de toekomst zou kunnen brengen. Het ex ante-perspectief heeft in die situatie dus niet te gelden.

72. Men kan zich afvragen wat nu precies de grondslag is voor een kapitalisatiepeildatum in het verleden wanneer dat moment niet daadwerkelijk als uitgangspunt wordt genomen bij de vaststelling van de schade: waarom wordt er dan nog naar een datum in het verleden gekapitaliseerd en wettelijke rente toegewezen vanaf die datum? Het lijkt meer voor de hand te liggen om de schade, die ten tijde van de schadeafwikkeling reeds is geleden en zich concreet laat vaststellen, te vergoeden in de vorm van een totaalbedrag dat overeenkomt met het totaal van de in de loop van de tijd al ontstane schadeposten (dus ex post benaderd), en alleen de schade die dan in de toekomst nog zal worden geleden bij voorbaat (ex ante) te begroten op een gekapitaliseerd bedrag ineens. ${ }^{\mathrm{I} 2}$

73. De keuze van de Hoge Raad wordt doorgaans verklaard met de hoofdvraag die in met name de eerste twee Peildatum-arresten speelde, namelijk de vraag naar verschuldigdheid van wettelijke rente ex artikel I286 Oud BW. Ten aanzien van periodiek verschijnende maar niet gekapitaliseerde schade gold namelijk dat, voor de verschuldigdheid van wettelijke rente, na het ontstaan van iedere afzonderlijke schadepost en het opeisbaar worden van de vergoeding ter zake telkens weer een nieuwe aanmaning nodig was, wat in de praktijk vaak niet gebeurde. Door de mogelijkheid van kapitalisatie met een peildatum in het verleden kan het ongewenste gevolg van die regeling, namelijk dat (veel) wettelijke rente werd misgelopen wanneer niet telkens opnieuw een aanmaning is verstuurd, worden opgeheven; de gehele 'toekomstschade' wordt immers geacht te zijn geleden op die peildatum. ${ }^{129}$ Het willen opheffen van die gevolgen is op zichzelf begrijpelijk (naar huidig recht is dit ook anders geregeld) maar het leidt wel tot een vreemde inconsistentie in

I27 Vgl. W.G. Verkruisen, 'Vertragingsrente: de praktische gevolgen van abstracte benadering', VR I998-3, p. 69.

I28 Vgl. A-G Wuisman onder punt 2.7 van zijn conclusie (ECLI:NL:PHR:2007:BA4606) voor HR 30 november 2007, RvdW 2007/1025.

I29 Het is in elk geval ook relevant omdat in WAM-zaken de wettelijke rente niet door de verzekerde som wordt 'gekeerd'. 
de wijze waarop het recht aan de vergoeding van voortdurende en 'toekomstige' schade vormgeeft.

Peildatum in het verleden en 'hybride' vaststelling van schade

74. Hoewel de genoemde Peildatum-arresten alle drie personenschadezaken betroffen, strekken de gevolgen zich in beginsel ook uit naar andere vormen van voortdurende schade zoals nog te maken kosten, of het derven van winst in de ondernemingssfeer. Ook daar speelt wel de vraag of over een verstreken periode - waar dus gesproken moet worden van 'reeds geleden schade' - nog met factoren moet worden gerekend die onzekerheid uitdrukken. Moet in geval van een voortdurende winstderving worden gerekend met een ex ante bepaalde disconteringsvoet waarmee (ook) het ondernemingsrisico naar het moment van de schadeveroorzakende gebeurtenis tot uitdrukking wordt gebracht (een zogenoemde 'hybride' schadevaststelling)? Doet zich hier een wezenlijk andere situatie voor dan wanneer het gaat om de sterftekanscorrectie bij letsel? Er vallen wel duidelijke verschillen te noemen tussen verlies aan verdienvermogen als gevolg van letsel en derving van winst in de ondernemingssfeer. Waar het om arbeidsvermogensschade gaat, staat er doorgaans steeds een voortdurende prestatie, die aan risico's (zoals sterftekans) onderhevig is, tegenover het inkomen. Dat kan anders liggen bij gevallen van winstderving in de ondernemingssfeer. Bovendien kan men persoonlijke 'verdiencapaciteit' ook niet door eenmalige verkoop te gelde maken, waar die mogelijkheid bij een (winstgevende) ondernemingsactiviteit wel kan bestaan. Maar de vraag is of dit onderscheid ook bij de schadebegroting een verschil moet maken.

75. Bij kapitalisatie met een peildatum in het verleden heeft te gelden - zo blijkt uit de overwegingen van de Hoge Raad - dat ernaar moet worden gestreefd zo veel mogelijk de daadwerkelijk geleden en te lijden schade volledig te vergoeden: met relevante ontwikkelingen die zich na de peildatum hebben voorgedaan moet daarom rekening worden gehouden. Het verdisconteren van ex ante geldende onzekerheden en risico's verhoudt zich hier lastig toe. Het komt uiteindelijk neer op de vraag of men bij de schadevaststelling steeds uitgaat van twee 'uitgestippelde' looplijnen (het verloop der dingen in de situatie met en de situatie zonder aansprakelijkheidscheppende gebeurtenis, hoezeer die vaststelling ook met onzekerheid gepaard gaat) of dat men meer expliciet uitdrukking geeft aan kansen en onzekerheden. Dat is overigens niet heel anders wanneer de reeds geleden schade ex post wordt vastgesteld en vergoed in de vorm van een totaalbedrag dat overeenkomt met het totaal van de al ontstane schadeposten, en waarbij de peildatum voor de toekomstige schade wordt gesteld op het moment van schadevaststelling. Ook in dat geval kan men zich afvragen of, en zo ja, hoe uiting moet worden gegeven aan ondernemingsrisico's, zowel ten aanzien van een reeds verstreken periode als ten aanzien van de toekomst.

76. Een in het verleden gelegen peildatum voor 'toekomstschade' in combinatie met een ex ante-disconteringsvoet, die mede wordt bepaald door een risico-opslag ter 'correctie' voor het ondernemingsrisico, maakt het niet bepaald eenvoudiger. Zien wij het goed, dan werkt een dergelijke 'risicocorrectie' naarmate gemiste inkomsten - vanaf de peildatum bezien - verder in de toekomst liggen in toenemende mate 'drukkend' op het schadebedrag, omdat de daaromtrent heersende 
onzekerheid ten tijde van de peildatum toeneemt. 'Vrij vertaald' naar de vraag naar de houdbaarheid van de sterftekanscorrectie bij letsel, zou dat neerkomen op de redenering: 'hoe ouder het slachtoffer inmiddels daadwerkelijk is geworden, des te groter het overlijdensrisico dat per peildatum voor deze voorbije jaren geldt, en hoe meer dit over de inmiddels voorbije jaren op de omvang van de schade wordt bekort'. Dat lijkt slecht te rijmen met het uitgangspunt van volledige schadevergoeding en het uitgangspunt dat schade zo veel als mogelijk concreet wordt vastgesteld.

77. Moet niet vanuit het oogpunt van consistentie met de uitgangspunten van het schadevergoedingsrecht worden uitgesloten dat de peildatum voor de kapitalisatie van voortdurende schade (ruim) vóór het tijdstip van de uitspraak kan worden gesteld, en dus als uitgangspunt gelden dat de kapitalisatiemethode uitsluitend wordt toegepast ten aanzien van daadwerkelijk toekomstige schade?

\section{$5 \cdot 5$ Slot}

78. Eigen aan het schadebegrip is dat steeds een vergelijking plaatsvindt tussen twee scenario's: het hypothetische verloop waarin er geen aansprakelijkheidscheppende gebeurtenis is en de werkelijke situatie van de benadeelde zoals die zich ontwikkelt. Bij voortdurende en toekomstige schade gaat het steeds om verwachtingen ten aanzien van ontwikkelingen, waarover door tijdsverloop mogelijk meer duidelijkheid ontstaat. Dat betekent dat verwachtingen tot op zekere hoogte kunnen worden bijgesteld. Daar is de 'causaliteitsdoorbreking' een voorbeeld van: de in de toekomst te verwachten schade wordt dan als het ware 'ingehaald' door een andere gebeurtenis, die hetzelfde nadelige gevolg in het leven roept. Waar verwachtingen gaandeweg moeten worden bijgesteld, kan de tijd dus vriend of vijand zijn waar het de begroting van voortdurende schade betreft.

\section{$6 \quad$ Schadeloosstelling wegens onteigening}

\section{I Inleiding}

79. Vanuit het tijdsverloopperspectief vormt ook de schadeloosstelling wegens onteigening een interessante figuur. Bij onteigening gaat het kort gezegd om de ontneming van een goed ten behoeve van het algemeen belang, en het onteigeningsrecht bevindt zich dan ook op het terrein van de schadevergoeding wegens rechtmatig overheidshandelen (bestuursrechtelijke schadevergoeding). ${ }^{130}$ De regels met betrekking tot de schadeloosstelling voor onteigening zijn in de afgelopen anderhalve eeuw grotendeels door de Hoge Raad tot stand gebracht, en enkele van de belangrijkste schadeloosstellingsregels zijn thans terug te vinden in de Onteigeningswet (OW).

I30 E. van der Schans \& A.C.M.M. van Heesbeen, Onteigening. Het spel en de knikkers, Doetinchem: Reed Business 20II, p. I3. 
8o. Uitgangspunt ten aanzien van de schadeloosstelling is dat zij een volledige vergoeding vormt voor alle schade die de eigenaar rechtstreeks en noodzakelijk lijdt door het verlies van zijn zaak (artikel $40 \mathrm{OW}) .{ }^{13 \mathrm{I}}$

Ten aanzien van onteigening overweegt de Hoge Raad in het arrest Van Rijswijk/ Amsterdam: 'Een onteigende wordt eerst dan volledig schadeloosgesteld indien hij zowel wat vermogen als wat inkomen betreft in een gelijkwaardige positie blijft. ${ }^{{ }^{132}}$

Uitgangspunt is dus dat de onteigende in beginsel aanspraak heeft op een vergoeding die hem in een vermogenspositie brengt die gelijkwaardig is aan de situatie waarin de onteigening wordt weggedacht. Dat brengt met zich dat de onteigende dus ook niet in een betere positie geplaatst moet worden. In dit opzicht wijkt het onteigeningsrecht dus niet af van het gemene schadevergoedingsrecht. De schadeloosstelling kan bestaan uit vergoeding van de zogenoemde 'werkelijke waarde' van wat wordt onteigend en van de eventuele 'waardevermindering van het overblijvende'. Daarnaast komt ook de 'bijkomende schade', die in allerlei schadeposten kan bestaan, voor vergoeding in aanmerking.

\subsection{Schadevaststelling: fixatie op peildatum}

8I. Bij het bepalen van de schadeloosstelling wegens onteigening wordt uitgegaan van de dag waarop de eigendomsovergang plaatsvindt, oftewel de dag waarop de inschrijving van een onherroepelijk onteigeningsvonnis in de Basisregistratie Kadaster (BRK) plaatsvindt (artikel 40a OW). Dat betekent dat alle schade in beginsel naar deze peildatum moet worden berekend, ongeacht op welk moment de schade door de rechter wordt vastgesteld en ongeacht de ontwikkelingen die in de tussentijd hebben plaatsgevonden. Sluysmans en Van der Gouw duiden het aldus:

'Wil enige zinvolle vaststelling van schade wegens onteigening mogelijk zijn, dan zal die schade moeten worden berekend op basis van een vast moment (...). Alle schade zal in beginsel moeten worden berekend naar de toestand van dat moment. We hebben hier duidelijk te maken met een fictie, die dwingt tot het abstraheren van zaken die ten tijde van het wijzen van een schadeloosstellingsvonnis wel bekend zijn (geworden), maar die omwille van het perspectief van de peildatum bij de oordeelsvorming toch geen rol mogen spelen.'133

Hier wordt dus voor een ex ante-perspectief per peildatum gekozen: wat de onteigeningsrechter moet doen is, bezien vanaf de peildatum, in zekere zin voorspellen wat de rechtstreekse en noodzakelijke gevolgen zijn van de eigendomsontneming. ${ }^{134}$ Dat valt te verklaren doordat het bij onteigening altijd om toekomstige schade gaat, namelijk de schade die na en als gevolg van het onteigeningsvonnis zelf wordt geleden. Hierin ligt een belangrijk verschil met de onrechtmatige daad,

I3I De Grondwet spreekt in art. I4 over schadeloosstelling bij onteigening, wat als volledige schadeloosstelling dient te worden geïnterpreteerd.

I32 HR I6 maart I988, NJ I989/798 m.nt. R.A. Morzer Bruyns (Van Rijswijk/Amsterdam), r.o. 3.

I33 J.A.M.A. Sluysmans \& J.J. van der Gouw, Onteigeningsrecht, Deventer: Kluwer 20I5, p. IOI.

I34 Vgl. J.A.M.A. Sluysmans, De vitaliteit van het schadeloosstellingsrecht in onteigeningszaken (diss. Leiden), 20II, p. 74 . 
waarbij een belangrijke plaats wordt ingenomen door de schade die op het tijdstip van het vonnis reeds geleden is (en waarvan bij de schadeloosstelling wegens onteigening dus geen sprake kan zijn). ${ }^{135}$

In het arrest Baksi/Den Haag speelde de vraag of Baksi aanspraak had op een vergoeding van de makelaarskosten die een redelijk handelende ondernemer zou maken wanneer deze op zoek zou moeten naar nieuwe bedrijfsruimte, terwijl lopende de procedure bleek dat Baksi zijn bedrijf reeds naar een locatie dicht bij de oude had weten te verplaatsen. De gemeente stelde dat de makelaarskosten niet voor vergoeding in aanmerking kwamen, nu Baksi uiteindelijk zelf vervangende ruimte had gevonden. De Hoge Raad overweegt: 'De dag waarop het vonnis van vervroegde onteigening is ingeschreven in de openbare registers is maatgevend voor de bepaling van de schadeloosstelling. De feiten en omstandigheden zoals die op die dag bestonden vormen uitgangspunt bij de bepaling en de begroting van de ten gevolge van de onteigening geleden schade. Dit kan er toe leiden dat de onteigeningsrechter de schadeloosstelling afstemt op een op basis van de op die dag bestaande situatie te verwachten handelwijze van de tot schadeloosstelling gerechtigde na de onteigening, ook al staat inmiddels vast dat die anders heeft gehandeld of anders zal handelen. Waar de Rechtbank in aanmerking nam dat op de onteigeningsdatum niet viel te voorzien dat zonder inschakeling van een makelaar vervangende ruimte zou kunnen worden gevonden, heeft zij in zoverre terecht de situatie van de dag van inschrijving van het vervroegde vonnis van onteigening als uitgangspunt genomen, en zij heeft dan ook niet van een onjuiste rechtsopvatting blijk gegeven door in de schadeloosstelling voor Baksi een post makelaarskosten op te nemen. ${ }^{136}$

82. Cruciaal is dus wat de op de dag waarop het vonnis van vervroegde onteigening is ingeschreven in de openbare registers te verwachten handelwijze was, ongeacht of later komt vast te staan hoe er daadwerkelijk door de onteigende is gehandeld.

Een iets ander geval was aan de orde in het arrest Onteigening Berkel en Rodenrijs, waarin het ging om de vraag of een later tijdens de procedure gebleken ernstige bodemverontreiniging van het onteigende moest worden meegenomen in de begroting van de schadeloosstelling. De op de peildatum heersende veronderstelling, dat de betreffende asbest zou zijn verwijderd, bleek dus onjuist. De Hoge Raad gaat uit van: '(...) de regel dat de dag waarop het vonnis van vervroegde onteigening is ingeschreven in de openbare registers (...) maatgevend is voor de bepaling van de schadeloosstelling. Deze regel belette (...) de rechtbank niet om bij die bepaling rekening te houden met asbestverontreiniging waarvan de deskundigen aanvankelijk veronderstelden dat deze voor de peildatum door Greeve was verwijderd, maar die zij, toen hun uit het Saneringsplan bleek dat die veronderstelling niet juist was, bij gelegenheid van de pleidooien alsnog in hun begroting van de schadeloosstelling hebben betrokken. De rechtbank diende immers ingevolge de voormelde regel rekening te houden met alle feiten en omstandigheden op de peildatum die van invloed zijn op de hoogte van de schadeloosstelling, ook als daarvan pas bleek uit rapporten van latere datum.' ${ }^{\text {'37 }}$ Uit deze overweging valt

I35 Vgl. A.R. Bloembergen, Schadevergoeding bij onrechtmatige daad, Deventer: Kluwer I965, nr. 5 .

I36 HR 28 maart 2003, NJ 2003/40I (Baksi/Den Haag), r.o. 4.I.

I37 HR 29 april 2005, NJ 2005/456 m.nt. P.C.E. van Wijmen (Onteigening Berkel en Rodenrijs), r.o. 3·3. 
af te leiden dat het gaat om alle feiten en omstandigheden die per peildatum aanwezig waren en die van invloed zijn op de hoogte van de schade.

83. Een complicatie is wel dat de onteigeningsrechter bij het per peildatum voorspellen van de rechtstreekse en noodzakelijke gevolgen van de eigendomsontneming moet 'wegkijken' van gebeurtenissen die zich na de peildatum voordoen, en per peildatum hoogstens als waarschijnlijkheid konden worden aangemerkt.

Een voorbeeld hiervan biedt het arrest Van de Wolfshaar|Amersfoort, waarin de vraag speelde of met - naar de peildatum gemeten - toekomstige regelgeving rekening moet worden gehouden bij de vaststelling van de onteigeningsschade. De Hoge Raad overweegt: 'Bij de berekening van de schadeloosstelling is de Rechtbank, nu geen bijzondere omstandigheden waren gesteld die noopten tot het maken van een uitzondering op de te dezen toepasselijke regel, terecht uitgegaan van de feitelijke toestand op het tijdstip van de inschrijving van het onteigeningsvonnis, te weten 2 mei 1997. Dit brengt met zich dat de Rechtbank geen rekening behoefde te houden met wettelijke welzijnsen milieueisen die op dat tijdstip nog niet golden. Dit neemt echter niet weg dat de Rechtbank bij de beoordeling van de feitelijke toestand op 2 mei 1997 wel rekening diende te houden met de kans dat binnen de door haar voorziene termijn waarin de verplaatsing van het bedrijf haar beslag zou krijgen, dergelijke wettelijke eisen zouden worden gesteld, en dat de Rechtbank een schatting diende te maken van de daaraan naar verwachting verbonden kosten.' ${ }^{138}$

\subsection{Kapitalisatie van voortdurende schade wegens onteigening}

84. Ook bij onteigening kan sprake zijn van voortdurende schade. Zo kan de onteigende inkomensverlies lijden of in de toekomst met extra terugkerende lasten worden geconfronteerd. Ook deze schade komt, als zogenoemde 'bijkomende' schade, voor vergoeding in aanmerking. Dat geschiedt door de schade te kapitaliseren en de naar de peildatum gemeten contante waarde van het bedrag van de schade gedurende de schadeperiode te vergoeden. In de rechtspraak zijn hiervoor zogenoemde 'factoren' ontwikkeld, waarbij een hogere factor wordt toegepast naarmate de onteigende een sterkere rechtspositie bekleedt (de eigenaar bekleedt een sterkere positie dan de pachter of de huurder). ${ }^{\mathrm{I} 9}$ Zo is voor een eigenaar de kapitalisatiefactor Io gebruikelijk, wat neerkomt op een schadeperiode van 13 jaar bij een rentevoet van $4 \%$. De jaarlijks terugkerende schade wordt dus met tien vermenigvuldigd. Deze factor is een 'fictie', een houvast voor de rechter. ${ }^{\mathrm{I} 40} \mathrm{In}$ de woorden van Telders:

'Vraag niet: waarom? Er is geen mens die dit zeggen kan. De rechter moet iets zeggen en hij zegt het eenvoudige: tien maal. Het enige wat hiervan te zegen valt is, dat de rechter hiermede niet gezegd heeft, dat de duur van de bedrijfsvoortzetting geschat moet

I38 HR I4 juli 2000, NJ 2000/628 m.nt. P.C.E. van Wijmen (Van de Wolfshaar|Amersfoort), r.o. 4.5.

I39 Zie J.A.M.A. Sluysmans, De vitaliteit van het schadeloosstellingsrecht in onteigeningszaken (diss. Leiden), $201 \mathrm{I}, \mathrm{p}$. I00.

I40 J.A.M.A. Sluysmans \& J.J. van der Gouw, Onteigeningsrecht, Deventer: Kluwer 2015, p. 143. 
worden op \pm 13 jaar en dat hij ook niet gezegd heeft, dat de rentestand in deze 13 jaar gemiddeld $4 \%$ zal zijn. Hij heeft met de woorden "tien maal" niets anders tot uitdrukking gebracht dan dat een eigenaar, voorzien van de aldus berekende som, de ongewisheden des levens zal kunnen ondergaan als ware hij niet onteigend. ${ }^{{ }^{141}}$

85. In de 'vaste' factor ziet men doorgaans een verdiscontering van allerlei risico's en mogelijkheden, wat bijdraagt aan de doelmatigheid en de rechtszekerheid.

\begin{abstract}
Van der Schans en Van Heesbeen merken hierover op: 'Zou men de factor Io prijsgeven, dan zou de schadebeoordeling terechtkomen in een chaotische verscheidenheid van factoren, met een wellicht van rechtbank tot rechtbank uiteenlopend resultaat. De conclusie is dat het ondoelmatig is het gebruik van de factor to te verlaten, zolang niet vaststaat dat voor de toepassing van een of meer andere factoren algemeen erkende, goede gronden aanwezig zijn.' ${ }^{142}$

In het arrest Leiden/Motorhuis overweegt de Hoge Raad ten aanzien van de toepasselijkheid van de factor Io: 'dat echter veeleer niet slechts denkbaar, doch bepaaldelijk meer voor de hand liggend is dat men tot een schadeperiode van $\mathrm{I} 3$ jaren komt doordat men bij het kapitaliseren van schaden, waarvan de schatting van het jaarlijkse bedrag berust op een vergelijking van de toestand voor de onteigening met de toestand daarna en waarvan de tijdsduur zelfs bij benadering moeilijk valt te schatten, intuïtief of afgaande op hetgeen men dikwijls heeft zien gebeuren, een vermenigvuldigingsfactor bezigt, welke niet voor alle groepen van gevallen gelijk behoeft te zijn doch in de meeste gevallen uitkomt op de factor ro, en welke met inachtneming van de eveneens gebruikelijke rentevoet van 4 procent overeenkomt met een tijdsduur van omstreeks 13 jaren'. ${ }^{43}$
\end{abstract}

In de praktijk ziet men doorgaans geen afwijking van de 'vaste' factoren. ${ }^{\text {I4 }}$ Voor een afwijking van wat gebruikelijk is, dient een rechtvaardiging te bestaan.

\title{
6.4 Slot: het perspectief van de peildatum
}

86. Binnen het onteigeningsrecht valt op dat alle schade naar de peildatum moet worden berekend, ongeacht op welk moment de schade door de rechter wordt vastgesteld en ongeacht de ontwikkelingen die in de tussentijd hebben plaatsgevonden. Uitgangspunt is ook hier dat de onteigende volledig wordt gecompenseerd, maar er wordt niettemin 'geabstraheerd' van zaken die ten tijde van het wijzen van een schadeloosstellingsvonnis wel bekend zijn omdat die vanwege het strikte 'peildatumperspectief' geen rol kunnen spelen. Men zou kunnen zeggen dat er dus weliswaar een volledige schadeloosstelling is, maar dat die slechts naar het moment van de peildatum gemeten als volledig moet worden gezien. Per peildatum wordt het nadeel van de onteigende ex ante bepaald: ten aanzien van gebeurtenissen van later datum kan men dus hooguit spreken van verwachtingen, ongeacht

I4I C.H. Telders, Schadeloosstelling voor onteigening, Zwolle: Tjeenk Willink ig68, nr. 55I.

I42 E. van der Schans \& A.C.M.M. van Heesbeen, Onteigening. Het spel en de knikkers, Doetinchem: Reed Business 20II, p. 236-237.

I43 HR I2 april I967, NJ I967/236 m.nt. N.J. Polak (Leiden/Motorhuis).

I44 J.A.M.A. Sluysmans \& J.J. van der Gouw, Onteigeningsrecht, Deventer: Kluwer 20I5, p. I44. 
of inmiddels door tijdsverloop is gebleken of die verwachtingen bewaarheid zijn geworden.

87. Het voorgaande roept de vraag op in hoeverre binnen het gemene schadevergoedingsrecht een voorbeeld kan worden genomen aan het 'eigen-aardige' terrein van de schadeloosstelling wegens onteigening, bijvoorbeeld wat betreft de strikte 'peildatumfixatie' en de 'vaste' kapitalisatiefactoren voor toekomstschade, die de rechtszekerheid en de doelmatigheid zouden dienen.

\section{$7 \quad$ Tijdsverloop en de begroting van immateriële schade}

\section{I Momentschade of duurschade?}

88. Geldt het hiervoor besprokene ook ten aanzien van 'ander nadeel dan vermogensschade'? In het voorgaande werd wel uitgegaan van het onderscheid tussen 'momentschade' en 'duurschade'. Zoals eerder opgemerkt bestaat de schade die voor vergoeding in aanmerking komt uit vermogensschade en uit ander nadeel, dit laatste voor zover de wet op vergoeding hiervan recht geeft (artikel 6:95 BW). Wanneer de benadeelde valt onder een van de in artikel 6:106 BW opgesomde gevallen, dan bestaat er een dergelijke verplichting tot vergoeding van immateriële schade. Men kan aan de hand van de gevallen waarin dergelijke schade voor vergoeding in aanmerking komt nader invulling geven aan het begrip 'immateriële schade'. Zo kan dit worden omschreven als personenschade - het gaat immers telkens om schade aan de persoon - in de vorm van vermindering van welzijn door pijn, verdriet, derving van levensvreugde enzovoort. ${ }^{145}$

89. Voor immateriële schade valt doorgaans aan te nemen dat er niet zozeer op één moment schade wordt geleden, maar dat het betreffende nadeel gedurende een langere periode bestaat. Spreekt men als het gaat om immateriële schade van vermindering van welzijn of van pijn, verdriet en gederfde levensvreugde, dan ligt het in de rede om een zekere duur daarvan te veronderstellen. ${ }^{\mathrm{I} 46}$ In cassatie kan worden getoetst of de rechter blijk heeft gegeven van een onjuiste opvatting omtrent het schadebegrip en ten aanzien van de wijze van begroting, en de Hoge Raad geeft in een aantal arresten enkele aanwijzingen waar het gaat om de te waarderen omstandigheden.

In het arrest $\mathrm{AMC} / \mathrm{O}$ ging het om een aidsbesmetting als gevolg van een medische fout (een vergissing met een injectiespuit). Ten tijde van de besmetting was het slachtoffer 57 jaar oud; als gevolg van de besmetting had hij nog slechts een zeer beperkte levensverwachting. De Hoge Raad overweegt dat de rechter bij de begroting van het smartengeld rekening dient te houden met alle omstandigheden, en in een geval als het onderhavige: 'met name aan enerzijds de aard van de aansprakelijkheid en anderzijds de aard, de duur en de intensiteit van de pijn, het verdriet en de gederfde levensvreugde die voor het slachtoffer het gevolg zijn van de gebeurtenis waarop de aansprakelijkheid

I45 S.D. Lindenbergh, Smartengeld, Deventer: Kluwer I998, p. 92.

I46 Zie Lindenbergh, GS Schadevergoeding, art. 6:Io6 BW, aant. 3·5. 
berust. Onder het verdriet is ook begrepen het verdriet dat het slachtoffer heeft doordat als gevolg van deze gebeurtenis zijn levensverwachting is bekort. ${ }^{\mathrm{I} 47}$

90. Niet alleen de duur van de pijn, het verdriet en de gederfde levensvreugde zelf is een omstandigheid waaraan 'met name' moet worden gedacht, maar ook het verdriet wegens het 'bekort zijn in de levensverwachting' wordt hier expliciet genoemd. Ook hier gaat het dus om een waardering van het nadeel dat het slachtoffer ondervindt, waarbij de nadelige vooruitzichten dus hun schaduw vooruitwerpen, zij het niet in financieel-economische zin maar in termen van verdriet.

In het arrest Cornelisse/Lokhorst (ook wel het Coma-arrest genoemd) ging het om een arbeidsongeval als gevolg waarvan het slachtoffer in coma raakte. De vraag rees of voor vergoeding van immateriële schade een zogenoemd 'bewustzijnsvereiste' geldt. De Hoge Raad beantwoordt die vraag ontkennend, maar overweegt dat de bewusteloosheid van het slachtoffer wel van belang kan zijn voor de vraag of, en zo ja, in welke mate nadeel wordt geleden dat voor vergoeding in aanmerking komt, en voor de vraag hoe deze vergoeding moet worden begroot: 'De omstandigheid dat de benadeelde gedurende een bepaalde periode bewusteloos is geweest, zal in het algemeen en behoudens aanwijzingen van het tegendeel, tot het oordeel kunnen leiden dat hij wat betreft die periode geen nadeel heeft geleden in de vorm van pijn en/of verdriet, doch deze omstandigheid rechtvaardigt niet zonder meer de conclusie dat in het geheel geen sprake is geweest van gederfde levensvreugde. Aangenomen moet immers worden dat de staat van bewusteloosheid in elk geval tot gevolg heeft gehad dat aan de benadeelde de mogelijkheid heeft ontbroken van zijn leven te genieten. (...) De rechter zal in een geval als het onderhavige waarin moet worden aangenomen dat de benadeelde zich (achteraf en in zekere mate) heeft gerealiseerd dat hij gedurende een bepaalde periode bewusteloos is geweest en niet (meer) zijn gewone leven heeft kunnen leiden, in beginsel in aanmerking moeten nemen dat de benadeelde als gevolg van het door hem opgelopen letsel gedurende deze periode (...) levensvreugde heeft gederfd. ${ }^{{ }_{1} 4^{8}}$ Dat het slachtoffer gedurende een bepaalde periode levensvreugde heeft gederfd, moet dus in beginsel in aanmerking worden genomen bij de begroting van het smartengeld.

9I. Het 'voortdurende karakter' van de immateriële schade kan men ook afleiden uit het feit dat het bij de vergoeding voor immateriële schade doorgaans neerkomt op compensatie van nadeel dat resteert nadat feitelijk herstel en vermogensherstel is bewerkstelligd: redelijke kosten ter beperking van de welzijnsvermindering kunnen immers als vermogensschade voor vergoeding in aanmerking komen, en er mogen van de benadeelde - wederom binnen de grenzen van de redelijkheid ook schadebeperkende maatregelen worden verwacht. Het gaat bij immateriële schade dus veelal om nadeel dat niet (meer) weg te nemen valt en daarmee dus een voortdurend karakter heeft.

92. Gaan wij ten aanzien van immateriële schade uit van een bepaalde schadeperiode (de periode gedurende welke het 'andere nadeel dan vermogensschade' wordt geleden), dan 'valt' het moment waarop deze schade wordt vastgesteld

I47 HR 8 juli I992, NJ I992/7I4 (AMC/0), r.o. 3.3.

I48 HR 20 september 2002, NJ 2004/II2 m.nt. J.B.M. Vranken (Cornelisse/Lokhorst), r.o. 3·4·4-3·5. 
en begroot dus, net als bij vermogensschade, ook steeds voor, tijdens of na die schadeperiode. Als het gaat om het moment waarnaar de schade wordt gemeten en/of het moment dat als peildatum heeft te gelden bij de begroting van de schade in een som ineens, stuit men wel op verschillen die samenhangen met de aard van de schade. Wat betreft de begroting van immateriële schade geldt immers dat zij naar billijkheid geschiedt (artikel 6:I06 lid I BW). Daarom is het in Nederland niet gebruikelijk om de immateriële schade 'op te delen' in (toekomstige) tijdvakken en door kapitalisatie terug te voeren tot één schademoment. Die meer 'verfijnde' berekening, waarmee een zekere exactheid in waarde wordt nagestreefd, verhoudt zich immers moeilijk tot de meer 'ruwe' manier waarop de immateriële schade als zodanig wordt begroot. Toekenning van een periodiek te betalen som smartengeld is in theorie wel mogelijk, maar blijkt hoogst ongebruikelijk. ${ }^{149}$ Dat laat evenwel de vraag open, wat de meest geëigende wijze is waarop naar de duur van het lijden van immateriële schade kan worden gedifferentieerd bij de begroting van het smartengeld. Kan het als een wat 'vage' omstandigheid worden meegewogen bij het billijkheidsoordeel, of ligt een meer rekentechnische variant (zoals de kapitalisatiemethode) voor de hand waarin aan de (geschatte) duur van het lijden op een concretere wijze uiting wordt gegeven?

\section{2 'Peildatum' en verschuldigdheid van wettelijke rente}

93. Welk moment is bepalend voor de begroting van immateriële schade? Waar de rechter uitdrukkelijk rekening dient te houden met alle omstandigheden en in het bijzonder met de gevolgen van het letsel voor de betrokkene, ${ }^{50}$ ligt een ex antebenadering ten aanzien van immateriële schade niet bepaald voor de hand: die ziet immers op wat ten tijde van de schadeveroorzakende gebeurtenis aan gevolgen mocht worden verwacht. Later optredende gebeurtenissen en later opkomende informatie moeten dus worden meegewogen bij de begroting van het smartengeld.

Deze benadering valt ook af te leiden uit de overwegingen van de Hoge Raad in het Baby Kelly-arrest. Dat arrest betrof onder meer een zogenoemde 'wrongful life'-vordering van een ernstig gehandicapt ter wereld gekomen kind waarvan vaststaat dat zij - door voortijdig afbreken van de zwangerschap - niet zou zijn geboren indien de verloskundige, bij wie de moeder onder behandeling stond, niet had nagelaten prenatale diagnostiek te laten verrichten waardoor de chromosomale afwijking van de vrucht aan het licht zou zijn gekomen. De Hoge Raad overweegt ten aanzien van de begroting van de immateriële schade van het kind: 'De rechter dient alle ter zake dienende omstandigheden op het moment van zijn beoordeling mee te wegen, waaronder in elk geval de wijze waarop Kelly zich inmiddels heeft ontwikkeld, de mate waarin zij door haar handicaps wordt belemmerd "normaal" te leven en de mate waarin zij daaronder lijdt. ${ }^{\text {I5I }}$

94. Het moment dat daarbij als 'peildatum' heeft te gelden - oftewel: het moment waarop de immateriële schade wordt geacht te zijn geleden - is op zijn minst van belang voor de verschuldigdheid van wettelijke rente (artikel 6:IIg BW), maar speelt

I49 S.D. Lindenbergh, Smartengeld, Deventer: Kluwer I998, p. 23 I.

I50 HR I7 november 2000, NJ 200I/2I5 m.nt. A.R. Bloembergen (Druijff/B.C.E. Bouw), r.o. 3.2.

I5I HR I8 maart 2003, NJ 2006/606 m.nt. J.B.M. Vranken (Baby Kelly), r.o. 4.I8. 
ook als het gaat om de mogelijkheid van opschorting en verrekening. Ook hier gaat het in feite om de vertaalslag van een schadeperiode naar een schademoment, wat dus van belang is voor de aanspraak op smartengeld als een vermogensrecht.

Zo overwoog de Hoge Raad in het arrest Van Brakel/Diaconessenhuis met betrekking tot het ontstaan van immateriële schade (in verband met verjaring naar oud recht) dat moet worden aangenomen dat deze schade is ontstaan en dus is geleden op het tijdstip waarop het schadetoebrengende feit plaatsvond, en dat daaraan niet afdoet dat sprake is van voortdurende schade: het zou namelijk gaan om afzonderlijke elementen van de schade die in haar geheel bestaat in de door de onrechtmatige daad veroorzaakte lichamelijke toestand van het slachtoffer. ${ }^{152}$

95. Bij de begroting van immateriële schade in een som ineens kan als peildatum worden gekozen het moment van intreden van de schade of het moment waarop deze schade wordt begroot, en men laat dit doorgaans afhangen van de wijze waarop wordt begroot. ${ }^{53} \mathrm{Wij}$ zien hier twee varianten, ervan uitgaande dat doorgaans duidelijk is welk moment als 'het' moment van de aansprakelijkheidscheppende gebeurtenis moet gelden. Gaat men uit van een waardering naar het moment waarop de schadebegroting plaatsvindt, dan gaat vanaf dat moment wettelijke rente lopen; wordt bij de begroting uitgegaan van het moment van de schadetoebrengende gebeurtenis, dan zal de wettelijke rente vanaf dat moment lopen. ${ }^{154}$ Toch ziet men uitspraken waarin die keuze niet altijd even scherp wordt gemaakt.

Een voorbeeld hiervan biedt de uitspraak van de Rechtbank Noord-Nederland waarin het ging om de aanspraak op smartengeld van een man die op schadelijke wijze de gevolgen waarnam van de verkrachting van en moord op zijn dochter (het betreft hier de zogenoemde 'shockschade'). Pas dertien jaar na het misdrijf werd de dader geïdentificeerd. De rechtbank weegt bij de begroting van de immateriële schade het gevolg mee dat de vader al die tijd heeft moeten leven met het gegeven dat er geen duidelijkheid was over de dader en diens motieven, en dat deze onzekerheid mede heeft bijgedragen aan zijn lijden, en waardeert in zoverre naar het tijdstip van begroting. De wettelijke rente wordt door de rechtbank evenwel toegewezen vanaf het moment van de confrontatie, omdat daarmee 'de kiem is gelegd voor het geestelijk letsel dat zich nadien (verder) heeft ontwikkeld'. ${ }^{55}$ Zou eenzelfde benadering zijn toegepast in de zaak waarin het ging om de verkrachting van een vrouw door militairen in het voormalig Nederlands-Indië in 1949, waarvoor de Nederlandse Staat aansprakelijk werd gehouden, dan zou dat een buitengewoon omvangrijke som aan wettelijke rente opleveren; de Rechtbank Den Haag begroot in die zaak de immateriële schade echter 'naar huidige

I52 HR I9 oktober 200I, NJ 200I/655 (Van Brakel/Diaconessenhuis), r.o. 3·3.

I53 Zie Lindenbergh, in: GS Schadevergoeding, art. 6:Io6 BW, aant. 4.5 en S.D. Lindenbergh, 'Smartengeld en wettelijke rente', Aansprakelijkheid, Verzekering \& Schade 2000-6, p. I37.

I54 De zaak ligt gecompliceerder wanneer niet alleen de geleden schade, maar ook de onrechtmatige gedraging zelf zich over een langere periode uitstrekt. Zie recentelijk Hof ArnhemLeeuwarden 5 april 2016, JA 2016/88 m.nt. A.I. Schreuder.

I55 Rb. Noord-Nederland II februari 20I5, JA $2015 / 43$ m.nt. M.R. Hebly, r.o. 6.9. 
maatstaven' en overweegt dat er daarom geen aanspraak bestaat op de vergoeding van wettelijke rente. ${ }^{156}$

96. Willekeur lijkt op dit vlak onwenselijk, gezien de belangen die ermee gemoeid kunnen zijn. Dat roept de vraag op hoeveel (begrotings)vrijheid het recht hier zou moeten toelaten: moet hier niet een - principiële - keuze worden gemaakt voor een begroting van immateriële schade naar het moment van de rechterlijke beslissing, waarbij dat moment dus ook steeds als 'peildatum' te gelden heeft en waarbij de immateriële schade dus ook moet worden geacht op dat moment te zijn geleden?

\section{Toerekening van opkomend voordeel}

\section{I Inleiding}

97. In het voorgaande is steeds over schade gesproken. Maar niet alleen ontvouwt zich met enig tijdsverloop de schade, ook zullen gaandeweg eventuele voordelen voor de benadeelde kunnen opkomen. Een aansprakelijkheidscheppende gebeurtenis kan naast een verslechtering immers ook een verbetering van de (vermogensrechtelijke) positie van de benadeelde als gevolg hebben. Denk hierbij aan kostenbesparing, belastingvoordelen, verzekeringsuitkeringen enzovoort. Artikel 6:Ioo BW bepaalt dat wanneer eenzelfde gebeurtenis voor de benadeelde 'naast schade tevens voordeel' heeft opgeleverd, dit voordeel bij de vaststelling van de te vergoeden schade in rekening moet worden gebracht voor zover dit redelijk is. Daarmee wordt beoogd te voorkomen dat de benadeelde door een schadeveroorzakende gebeurtenis in een betere positie komt te verkeren: hij mag niet zonder meer worden verrijkt door zijn schade volledig vergoed te krijgen en daarenboven ook het daarnaast verkregen voordeel te behouden. Het gaat hier om een algemeen aanvaard beginsel. ${ }^{157}$ In zijn algemeenheid is de redelijkheid van het in mindering brengen van voordelen ook amper voorwerp van debat. ${ }^{158}$ Over de grondslag waarop dit beginsel berust en over de wijze waarop het leerstuk 'werkt', bestaat evenwel geen eenstemmigheid, en ook over de vraag welke voordelen in concreto moeten worden verrekend wordt wel gedebatteerd.

98. Het toerekenen van voordelen bij de bepaling van de omvang van de schadevergoeding kan worden gegrond in het schadebegrip. Tot het bedrag van het voordeel wordt er geen schade geleden, zo luidt dan de redenering. Het in aanmerking nemen van voordeel zou dan slechts een aspect van de (feitelijke) schadebegroting zijn, en eventuele voordelen worden dan dus als een 'zuiver schadeverweer' door de aangesproken partij gevoerd. De andere benadering houdt in dat schade en voordeel afzonderlijk van elkaar moeten worden bezien ('schade naast

I56 Rb. Den Haag 27 januari 20I6, NJF 20I6/I48, r.o. 4.70. Een beroep op verjaring aan de zijde van de Staat wordt in die zaak verworpen, waardoor het ging om de gevolgen van een onrechtmatige daad uit een bijzonder ver verleden (bijna 7o jaar geleden).

I57 Zie ook art. IO:I03 PETL: 'When determining the amount of damages benefits which the injured party gains through the damaging event are to be taken into account unless this cannot be reconciled with the purpose of the benefit.'

I58 Zie Parl. Gesch. BW Boek 6, p. 348-350 en Parl. Gesch. BW Inv. Boek 6, p. I288 e.v. 
voordeel', de bewoording van artikel 6:Ioo BW). Aan de hand van de maatstaf van de redelijkheid kan dan worden beoordeeld of voordelen op de schadevergoeding in mindering moeten worden gebracht. De vraag is - zeker sinds het hierna nog te bespreken arrest Tenne T c.s.|ABB c.s. - in hoeverre deze twee benaderingswijzen (voordeel als schadekwestie of als schadevergoedingskwestie) wezenlijk van elkaar verschillen.

\section{2 'Eenzelfde gebeurtenis' die voordeel oplevert?}

99. Een minimumvoorwaarde voor voordeelstoerekening is dat schade en voordeel door 'eenzelfde gebeurtenis' zijn veroorzaakt, oftewel dat er een condicio sine qua non-verband bestaat tussen het schadegebeuren en het voordeel. Ten aanzien van de vraag hoe strikt het begrip 'eenzelfde gebeurtenis' moet worden uitgelegd bestond tot voor kort volop discussie, en spelen zich ook thans nog interessante ontwikkelingen af. De Hoge Raad vulde voorheen het begrip streng in door niet snel aan te nemen dat een voordeel voortvloeit uit de aansprakelijkheidscheppende gebeurtenis. ${ }^{159}$ Dat stuitte op kritiek in de literatuur, die er in de kern genomen op neerkomt dat de begrenzing van het toepassingsbereik van het leerstuk van de voordeelstoerekening te zeer wordt gezocht in het oordeel over de causale relatie tussen de gebeurtenis en het voordeel, en niet in de vraag naar de redelijkheid van het in rekening brengen van voordeel bij de vaststelling van de te vergoeden schade. ${ }^{160}$

In TenneT c.s.|ABB c.s. komt de Hoge Raad terug op zijn arresten waarin het begrip 'eenzelfde gebeurtenis' restrictief werd uitgelegd. ${ }^{16 r}$ Het ging in dat arrest om schadevergoeding wegens mededingingsinbreuk. In cassatie gaat het om de vraag welke ruimte het Nederlandse recht biedt voor het zogenoemde doorberekeningsverweer (passing-on defence). Dat verweer komt kortweg hierop neer dat inbreukmaker ABB stelt dat benadeelde TenneT geen schade heeft geleden door de inbreuk, of daar althans een voordeel door heeft genoten, nu TenneT de schade (de hogere prijzen) weer heeft doorberekend of nog zal doorberekenen aan haar eigen afnemers. Moet dit aspect worden beoordeeld als een onderdeel van de schadevaststelling of als een vraag van voordeelstoerekening? De Hoge Raad overweegt: 'Die stelling kan in beginsel worden betrokken zowel op het schadebegrip waarin de omvang van de schade wordt bepaald door een vergelijking van de toestand zoals deze in werkelijkheid is met de toestand zoals die (vermoedelijk) zou zijn geweest indien het schadeveroorzakende feit niet zou hebben plaatsgevonden (art. 6:95-6:97 BW), als op de voordeelstoerekening (art. 6:100 BW). Voor de beoordeling van een doorberekeningsverweer zijn dus twee

I59 Zo blijkt uit HR II februari 2000, NJ 2000/275 (De Preter/Van Uitert), HR 29 september 2000, NJ 200I/I05 m.nt. Bloembergen (Paulissen/Staat) en HR ro juli 2009, NJ 20II/43 m.nt. Hijma (Vos/ TSN).

I6o Zie bijv. F.B. Bakels, Ontbinding van overeenkomsten (Mon. BW nr. B58) 20II/88, S.D. Lindenbergh, 'Over wat schade is... en waarom het bij de vaststelling daarvan in de praktijk zo dikwijls mis gaat', WPNR 20I0/6867, p. 909, A.J. Rijsterborgh, 'Een zelfde gebeurtenis in art. 6:100 BW', AV\&S 20I2/6, Chr. Van Dijk, 'Voordeelstoerekening', in: U. Magnus \& Chr. Van Dijk, Voordeelstoerekening naar Duits en Nederlands recht, preadvies Vereniging voor Aansprakelijkheids- en Schadevergoedingsrecht (VASR), Deventer: Kluwer 2015, p. 4I.

I6I De Hoge Raad leek overigens reeds naar een minder strikte interpretatie te neigen in HR 29 april 20II, NJ 20I3/40 m.nt. Vranken (Van der Heijden/Dexia Bank Nederland). 
benaderingen denkbaar. (...) Het maken van een keuze tussen de beide benaderingen is in zoverre niet van belang, dat door de benadeelde in verband met de schadeveroorzakende gebeurtenis behaalde voordelen in beide benaderingen in de toe te kennen schadevergoeding moeten worden betrokken voor zover dat redelijk is. ${ }^{962}$

Vervolgens gaat de Hoge Raad meer specifiek in op het leerstuk van de voordeelstoerekening en komt hij uitdrukkelijk terug op zijn eerdere uitspraken: 'Bij de beoordeling van een beroep op voordeelstoerekening (art. 6:100 BW) gaat het erom dat genoten voordelen, voor zover dat redelijk is, mede in aanmerking behoren te worden genomen bij de vaststelling van de te vergoeden schade (...). Daarvoor is allereerst vereist dat tussen de normschending en de gestelde voordelen een condicio sine qua non-verband bestaat, in die zin dat in de omstandigheden van het geval sprake is van een voordeel dat zonder de normschending niet zou zijn opgekomen. Voorts dient het met inachtneming van de in art. 6:98 BW besloten maatstaf redelijk te zijn dat die voordelen in rekening worden gebracht bij de vaststelling van de te vergoeden schade. Waar in eerdere uitspraken van de Hoge Raad meer of andere eisen zijn gesteld aan "eenzelfde gebeurtenis" bij voordeelstoerekening met toepassing van art. 6:Ioo BW, komt de Hoge Raad daarvan terug. (...)'

Dit betekent volgens de Hoge Raad dat de rechter vrij is om te kiezen welke benadering hij ten aanzien van het doorberekeningsverweer volgt: 'In beide benaderingen gaat het uiteindelijk erom dat bij de vergelijking tussen de toestand zoals deze in werkelijkheid is en de toestand zoals die (vermoedelijk) zou zijn geweest indien de normschending niet zou hebben plaatsgevonden, beoordeeld moet worden welke nadelen en welke voordelen in zodanig verband staan met de gebeurtenis waarop de aansprakelijkheid van de schuldenaar berust, dat zij redelijkerwijs als een gevolg van deze gebeurtenis aan de schuldenaar kunnen worden toegerekend. ${ }^{163}$

Allereerst is dus vereist dat er sprake is van condicio sine qua non-verband tussen de aansprakelijkheidscheppende gebeurtenis en het voordeel, waarna het aankomt op de vraag of het redelijk is dat die voordelen in rekening worden gebracht bij de vaststelling van de te vergoeden schade. ${ }^{164}$

\subsection{Toerekening van 'abstracte' of toekomstige voordelen?}

Ioo. Uitgangspunt is dat slechts van voordeelverrekening ex artikel 6:100 BW sprake kan zijn wanneer een voordeel daadwerkelijk is genoten (of naar redelijke verwachtingen zal worden genoten).

Zoveel kan worden opgemaakt uit het arrest Van Straaten c.s.|Brandt c.s. ${ }^{165}$ Als gevolg van een verkeersongeval raakt een bejaard echtpaar ernstig gewond, waardoor zij tot hun overlijden in een ziekenhuis, een verpleegtehuis en als laatste in een verzorgingstehuis woonden. Gedurende die periode hebben zij hun echtelijke woning aangehouden en niet verkocht of verhuurd. Volgens het hof dienen in het kader van artikel 6:10o BW niet alleen de wegvallende gebruikelijke bewoningskosten te worden berekend, maar ook

I62 HR 8 juli 20I6, ECLI:NL:HR:20I6:I483 (TenneT c.s.|ABB c.s.), r.o. 4.4.I-4.4.2.

I63 HR 8 juli 20I6, ECLI:NL:HR:20I6:I483 (TenneT c.s.|ABB c.s.), r.o. 4.4.5.

I64 Deze benadering werd in de literatuur reeds bepleit (zie eerder aangehaald).

I65 HR I februari 2002, NJ 2002/I22 (Van Straaten c.s./Brandt c.s.). 
de huurwaarde die vrijkomt door het einde van de eigen bewoning. De Hoge Raad casseert: 'Indien in een concreet geval beoordeeld moet worden of eenzelfde gebeurtenis die voor een benadeelde schade heeft opgeleverd, voor hem tevens een voordeel heeft opgeleverd dat bij de vaststelling van de te vergoeden schade in rekening moet worden gebracht, dient de rechter in de eerste plaats te onderzoeken of het gestelde voordeel in voldoende causaal verband staat met de schadebrengende gebeurtenis. De rechter is vervolgens vrij bepaalde voordelen niet in rekening te brengen indien hem dat niet redelijk voorkomt. Voorts dient tot uitgangspunt te worden genomen dat van voordeelstoerekening slechts sprake kan zijn indien een voordeel werkelijk is genoten, of naar redelijke verwachtingen daadwerkelijk genoten zal worden. Een en ander is in overeenstemming met de strekking van de wet, erop neerkomende dat aan de benadeelde het feitelijk nadeel dat voor hem uit een tot schadevergoeding verplichtende gebeurtenis voortvloeit, wordt vergoed. ${ }^{366}$

IOI. Voor de toerekening van een meer 'abstract' voordeel is dus in beginsel geen plaats: het dient te gaan om een voordeel dat reeds daadwerkelijk is genoten, of naar redelijke verwachtingen daadwerkelijk nog zal worden genoten. Wanneer een vrijgekomen huurwaarde zich niet heeft 'verwezenlijkt', is geen sprake van een feitelijk maar slechts van een 'abstract' voordeel en bestaat er dus geen grond voor voordeelstoerekening. Binnen het kader van de voordeelstoerekening is dus slechts plaats voor een ex ante-perspectief waar het om een voordeel gaat dat, bezien naar het moment waarop het wordt vastgesteld, naar redelijke verwachtingen nog zal worden genoten. Omtrent voortdurende en toekomstige voordelen kan dezelfde onzekerheid heersen als ten aanzien van voortdurende en toekomstige schade. Het komt dan in het kader van de voordeelstoerekening evengoed aan op de redelijke verwachting van de rechter omtrent toekomstige ontwikkelingen, waarbij goede en kwade kansen moeten worden afgewogen (artikel 6:105 BW).

I02. In dit verband kan men zich afvragen of de 'verrekening' van rendementsvoordelen via de rekenrente, die de benadeelde partij zou genieten door belegging van de toegekende schadevergoeding in een som ineens, wel zo vanzelfsprekend is. ${ }^{167}$ Dit geldt althans wanneer men de grondslag voor die rendementsverrekening zoekt in het leerstuk van de voordeelstoerekening, wat onzes inziens wel zou moeten. Waar als uitgangspunt geldt dat van voordeelstoerekening slechts sprake kan zijn indien een voordeel naar redelijke verwachtingen daadwerkelijk genoten zal worden, gaat het er dus om of de benadeelde het toegekende bedrag aan schadevergoeding naar redelijke verwachting daadwerkelijk en met succes zal aanwenden. Moet de discussie over de rekenrente niet veel meer in het licht van de voordeelstoerekening worden gevoerd, en verdient de vraag naar de redelijkheid van het in mindering brengen van (de mogelijkheid van) rendement daarbij niet wat meer aandacht?

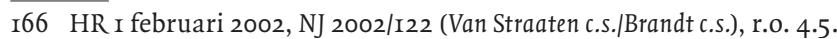

I67 Zie hierover eerder par. 5.4. 


\section{Schade in de vorm van kosten}

\section{I Inleiding}

I03. Artikel 6:96 lid 2 BW ziet op door de benadeelde te maken kosten van schadebeperking en schadevoorkoming, en op kosten van schadevaststelling en de kosten ter verkrijging van voldoening buiten rechte. De benadeelde zal immers zo veel mogelijk willen voorkomen dat hij schade lijdt en, wanneer hij daarin niet is geslaagd, de schade zo veel mogelijk willen beperken. De benadeelde zal bovendien veelal kosten maken in verband met het vaststellen van de schade en de aansprakelijkheid, en uiteindelijk zal de benadeelde ook kosten maken ter verkrijging van voldoening buiten rechte. Men spreekt hier in de praktijk wel van de 'buitengerechtelijke kosten'. Deze kosten worden in het algemeen pas gemaakt nadat de initiële schadeveroorzakende gebeurtenis heeft plaatsgehad, en dus nadat de 'primaire' schade is ontstaan. ${ }^{168}$ Deze vormen van vermogensschade vormen bovendien een bijzondere categorie in die zin, dat zij weliswaar als een gevolg van de aansprakelijkheidscheppende gebeurtenis kunnen worden aangemerkt, maar steeds wat betreft hun bestaan en omvang afhankelijk zijn van het initiatief en inzicht van de benadeelde. ${ }^{169}$ Daarom is steeds de redelijkheid beslissend voor de vraag in hoeverre de door de benadeelde gemaakte kosten voor vergoeding in aanmerking komen. Artikel 6:96 BW bevat een 'dubbele redelijkheidstoets', inhoudende dat niet alleen het maken van kosten redelijkerwijze verantwoord moet zijn, maar ook dat de kosten in hun omvang redelijk zijn. ${ }^{170}$ Het recht op vergoeding van de volledige vermogensschade wordt dus in die zin ingeperkt dat het op de weg van de benadeelde ligt om te voorkomen dat kosten nodeloos worden gemaakt of onredelijk hoog oplopen. De redelijkheid van de kosten dient prospectief te worden beoordeeld: wanneer achteraf zou blijken dat de gemaakte kosten lager hadden kunnen uitvallen, leidt dat nog niet tot het oordeel dat de kosten ex ante niet redelijk waren. ${ }^{17 \mathrm{I}}$

\subsection{Redelijke kosten ter voorkoming of beperking van schade}

I04. De vergoedbaarheid van de redelijke kosten ter voorkoming of beperking van schade (artikel 6:96 lid 2 sub a BW) vormt het complement van de op de benadeelde rustende verplichting om de schade zoveel als redelijkerwijs mogelijk is te voorkomen en te beperken. ${ }^{172}$ Die verplichting ligt besloten in artikel 6:IoI BW, op grond waarvan de vergoedingsplicht kan worden verminderd wegens eigen schuld aan

I68 Vgl. Verbintenissen uit de wet en Schadevergoeding (Hartlief), nr. 205. Soms worden kosten ter beperking van schade voorafgaand aan de schadeveroorzakende gebeurtenis gemaakt.

I69 Lindenbergh, Schadevergoeding: algemeen, deel 1 (Mon. BW nr. B34) 20I4/4IA en S.D. Lindenbergh e.a. (red.), Buitengerechtelijke kosten: vijf visies op de redelijkheid, Den Haag: Stichting Personenschade Instituut van Verzekeraars (PIV) 2000, p. I6.

I70 Aldus onder meer MvA II op art. 96, Parl. Gesch. BW Boek 6, p. 337, Asser/Hartkamp \& Sieburgh 6-II 2013/30 en S.D. Lindenbergh, 'Buitengerechtelijke kosten; grondslag en betekenis daarvan', in: S.D. Lindenbergh e.a. (red.), Buitengerechtelijke kosten, vijf visies op redelijkheid, Den Haag: Stichting Personenschade Instituut van Verzekeraars (PIV)2000, p. 20 e.v.

I7I Lindenbergh, Schadevergoeding: algemeen, deel 1 (Mon. BW nr. B34) 20I4/4IA en A.L.M. Keirse, Schadebeperkingsplicht. Over de eigen schuld aan de omvang van de schade, Deventer: Kluwer 2003, p. 282.

I72 Vgl. Asser/Hartkamp \& Sieburgh 6-II 20I3/28. 
de zijde van de benadeelde of, in dit geval meer specifiek door het tekortschieten in diens schadebeperkingsplicht. Het is immers alleen dan redelijk om van de benadeelde te verlangen dat hij zijn schade beperkt, wanneer zijn redelijke kosten voor vergoeding in aanmerking komen. Overigens is niet vereist dat de getroffen maatregelen ook daadwerkelijk tot voorkoming of beperking van schade hebben geleid: voldoende is dat de kosten met dat doel zijn gemaakt en dat zij met het oog op dat doel redelijk waren. ${ }^{173}$ Ook geldt niet als vereiste dat de kosten steeds lager moeten zijn dan de schade. ${ }^{174}$

I05. Ook kosten die zijn gemaakt vóór het tijdstip van de aansprakelijkheidscheppende gebeurtenis, maar met het oog op de voorkoming of beperking van schade, komen onder omstandigheden voor vergoeding in aanmerking. Het gaat hier niet om kosten die geheel ter voorkoming van schade in het algemeen zijn gemaakt maar om kosten die, gelet op het verband tussen de (verwachte) gebeurtenis en de genomen maatregelen, als een 'gevolg' van die gebeurtenis kunnen worden beschouwd. ${ }^{175}$ Als voorbeelden kunnen worden genoemd het inzetten van reservematerieel ter vervanging van een beschadigd bedrijfsmiddel, kosten van voorzieningen ter voorkoming van milieuschade en kosten van instandhouding van een auteursrechtbureau. ${ }^{176}$

\subsection{Kosten ter vaststelling van schade en aansprakelijkheid}

Io6. Onder kosten ter vaststelling van schade en aansprakelijkheid vallen te noemen expertisekosten, kosten van juridisch advies en kosten gemaakt in het kader van het verzamelen van bewijs. Deze regeling is praktisch van grote betekenis op het terrein van de personenschade, nu het voor slachtoffers mogelijk wordt gemaakt om (uiteindelijk) op kosten van de aansprakelijke te onderzoeken of er aansprakelijkheid bestaat, en zo ja, voor welke schade. ${ }^{177}$ Artikel 6:96 lid 2 sub b BW biedt geen zelfstandige grondslag voor de vergoeding van deze kosten, maar veronderstelt daarvoor het bestaan een wettelijke verplichting tot schadevergoeding. De vraag kan daarom gesteld worden, of dit type kosten ook voor vergoeding in aanmerking komt wanneer (nog) niet vaststaat of door de normschending wel schade is veroorzaakt.

In het arrest Bravenboer/London wordt deze vraag door de Hoge Raad bevestigend beantwoord. Het ging in die zaak om de vraag naar de vergoedbaarheid van advocaat- en onderzoekskosten, gemaakt met het oog op het vaststellen van de omvang van de schade als gevolg van een aanrijding, terwijl (nog) niet is komen vast te staan dat die schade daadwerkelijk is geleden. De Hoge Raad overweegt: 'Omdat degene die aansprakelijk is voor de schadelijke gevolgen van een door hem veroorzaakte aanrijding (...) in beginsel

I73 Aldus MvA II, Parl. Gesch. BW Boek 6, p. 334-335.

I74 HR I8 september I998, NJ I999/69 m.nt. A.R. Bloembergen (Bijenspat II).

I75 Zie MvA II, Parl. Gesch. BW Boek 6, p. 335-336.

I76 Lindenbergh, in: GS Schadevergoeding, art. 6:96 BW, aant. II.2.3 (online, laatst bijgewerkt I3 augustus 20I5). De vraag of er wel een causaal verband bestaat tussen de onrechtmatige daad en het tevoren in reserve houden van materieel kan op bedrijfseconomische gronden bevestigend worden beantwoord. Zie Asser/Hartkamp \& Sieburgh 6-II 20I3/28.

I77 Verbintenissen uit de wet en Schadevergoeding (Hartlief), nr. 205. 
binnen de grenzen van art. 6:98 BW aansprakelijk is voor alle schade die de benadeelde als gevolg van die gebeurtenis heeft geleden, kunnen de (redelijke) kosten ter vaststelling van schade en aansprakelijkheid ook voor vergoeding in aanmerking komen wanneer uiteindelijk niet komt vast te staan dat schade is geleden. Wel moeten die kosten als gevolg van de aanrijding zijn gemaakt (sine-qua-non-verband) en dienen zij tevens in een zodanig verband met de aanrijding te staan dat zij aan de daarvoor aansprakelijke persoon, mede gezien de aard van de aansprakelijkheid en van de schade, als gevolg van deze gebeurtenis kunnen worden toegerekend. ${ }^{178}$

De kosten kunnen dus (alsnog) voor vergoeding in aanmerking komen op grond van de algemene bepalingen inzake aansprakelijkheid en causaal verband. De Hoge Raad overweegt daarbij dat het verstrijken van tijd tussen de aanrijding en het maken van de kosten bij deze beoordeling nog wel een probleem kan vormen: 'Bij het voorgaande verdient aantekening dat, naarmate de tijd verstrijkt, de vraag meer kan gaan klemmen of tussen de aanrijding en de gevorderde kosten nog wel causaal verband (in de zin van sine-qua-non-verband) bestaat. In beginsel ligt het op de weg van de benadeelde die vergoeding van kosten als de onderhavige vordert, om dit verband bij voldoende gemotiveerde betwisting daarvan te bewijzen. De rechter kan echter in de omstandigheden van het geval aanleiding zien dit bewijs voorshands geleverd te achten. Daarbij zullen met name de aard en de ernst van de nader te onderzoeken aanwijzingen voor het bestaan van letsel en de mate van waarschijnlijkheid dat dit letsel in verband staat met het ongeval van belang zijn. ${ }^{\text {'79 }}$ Van belang is dat het hier om letselschade gaat die zich pas later openbaart, waarbij de mate van waarschijnlijkheid dat dit letsel in verband staat met het ongeval door tijdsverloop kan afnemen. Overigens geldt ook buiten de sfeer van de personenschade de regel dat voor de vergoedbaarheid van buitengerechtelijke kosten niet hoeft komen vast te staan dat er daadwerkelijk schade is geleden. ${ }^{180}$

\subsection{Kosten ter verkrijging van voldoening buiten rechte}

I07. Onder de kosten ter verkrijging van voldoening buiten rechte (artikel 6:96 lid 2 sub c BW) vallen de kosten van ingebrekestelling en de buitengerechtelijke incassokosten. Ook voor de vergoedbaarheid van deze kosten wordt verondersteld dat een wettelijke verplichting tot schadevergoeding bestaat. Vereist is dat deze kosten redelijk zijn en dat de verrichte werkzaamheden redelijkerwijs noodzakelijk waren om schadevergoeding te verkrijgen. ${ }^{18 \mathrm{r}}$ Dat kosten in overeenstemming zouden zijn met richtlijnen - door werkgroepen zijn wel aanbevelingen ontwikkeld voor de vaststelling van de omvang van te vergoeden buitengerechtelijke kosten - neemt niet weg dat de rechter de toetsing op redelijkheid moet verrichten. ${ }^{182}$ In letselschadezaken worden onder bepaalde partijen de buitengerechtelijke kosten van rechtsbijstand wel vastgesteld op een forfaitair bedrag, zodat discussie over de

I78 HR Ir juli 2003, NJ 2005/50 m.nt. J.B.M. Vranken (Bravenboer/London), r.o. 3.5·3.

I79 HR II juli 2003, NJ 2005/50 m.nt. J.B.M. Vranken (Bravenboer/London), r.o. 3.5.4.

I80 HR I3 maart 2015, NJ 2015/I45 (Mark Four Enterprises/Apotex Nederland).

I8I Zie MvA II, Parl. Gesch. BW Boek 6, p. 337 en HR I6 oktober I998, NJ I999/I96 m.nt. A.R. Bloembergen (Amev/Staat).

I82 HR 27 april 20I2, NJ 20I2/277 (Groenegeest/Proosdijen). Zie ook Asser/Hartkamp \& Sieburgh 6-II $2013 / 30$. 
redelijkheid van buitengerechtelijke kosten zo veel mogelijk wordt voorkomen. ${ }^{183}$ Het betreft hier immers een vorm van schade die niet zelden aanleiding geeft tot discussie. De mogelijkheid van het verhalen van de kosten van rechtsbijstand op de wederpartij (ook wel fee shifting genoemd) kan onder meer tot gevolg hebben dat er aan de zijde van de benadeelde méér aan kosten van rechtsbijstand wordt uitgegeven: 'de rekening gaat toch naar de aansprakelijkheidsverzekeraar' ${ }^{184} \mathrm{Men}$ stelt zich wel de vraag of er binnen dit systeem wel voldoende 'prikkels' zijn voor de rechtshulpverlener van de benadeelde om te voorkomen dat de kosten nodeloos worden gemaakt of onredelijk hoog oplopen (het betreft immers hun eigen beloning).

\subsection{Proceskosten en het 'verschieten van kleur'}

I08. Procederen wordt, ook als dat niet tot een gunstig resultaat leidt, op zichzelf niet als onrechtmatig aangemerkt. ${ }^{185}$ De ratio daarvan ligt in de vrijheid om anderen in rechte te betrekken en eigenrichting te voorkomen. De veroordeling tot vergoeding van de proceskosten berust dan ook niet op onrechtmatige daad of wanprestatie, en wordt ook niet gerekend tot het terrein van het schadevergoedingsrecht. ${ }^{186}$ De kosten waarop artikel 6:96 lid 2 onder b en c BW ziet, omvatten dus niet de proceskosten: deze worden uitsluitend beheerst door artikel 237 e.v. Wetboek van Burgerlijke Rechtsvordering. Een proceskostenveroordeling vindt plaats op basis van het zogenoemde 'liquidatietarief', dat doorgaans lager ligt dan de daadwerkelijk gemaakte kosten. De proceskosten en de buitengerechtelijke kosten kunnen elkaar 'overlappen', doordat kosten die als buitengerechtelijke kosten voor vergoeding in aanmerking komen op grond van artikel 6:96 lid 2 BW als proceskosten moeten worden aangemerkt indien het tot een procedure komt en deze kosten door de proceskostenveroordeling worden 'gedekt'. Men spreekt hier ook wel over het 'van kleur verschieten' van de kosten. ${ }^{187}$

\subsection{Slot}

I09. De hier besproken kostenposten (bereddingskosten, administratie- en expertisekosten en incassokosten), die als vermogensschade kwalificeren, hebben in die zin een bijzonder karakter, dat zij niet als de 'primaire' schade worden aangemerkt - zij moeten immers ook in een redelijke verhouding tot dat 'primaire' schadebedrag worden gemaakt - en dat zij steeds wat betreft hun bestaan en om-

I83 Zie hierover onder meer J. Sap, 'Op weg naar normering van buitengerechtelijke kosten', TVP 2008/2, p. 45-50; J. Wildeboer, 'Buitengerechtelijke kosten', in: P. Langstraat e.a., De kosten van het geschil: inleidingen gehouden op het symposium van de Vereniging van Letselschade Advocaten 2008, Den Haag: Sdu Uitgevers 2008, p. 26-32 en W.S. de Vries, 'Normering van Buitengerechtelijke kosten', in: S.D. Lindenbergh e.a. (red.), Buitengerechtelijke kosten: vijf visies op de redelijkheid, Den Haag: Stichting Personenschade Instituut van Verzekeraars (PIV) 2000, p. 87-I03.

I84 Zie voor empirisch onderzoek naar de ontwikkeling van honoraria van belangenbehartigers in letselschadezaken M. Faure, T. Hartlief \& N. Philipsen, Resultaatgerelateerde beloningssystemen voor advocaten. Een vergelijkende beschrijuing van beloningssystemen voor advocaten in een aantal landen van de Europese Unie en Hong Kong, Den Haag: WODC/Ministerie van Justitie 2006.

I85 HR 27 juni I997, NJ I997/65I.

I86 HR I8 februari 2005, NJ 2005/2I6.

I87 Een metafoor ontleend aan Brunner in zijn NJ-noot onder HR 3 april I987, NJ I988/275 (L\&L/ Drenth). 
vang afhankelijk zijn van het handelen van de benadeelde. De omvang van de kosten wordt weliswaar ex post vastgesteld; de redelijkheid van het maken ervan wordt evenwel prospectief beoordeeld, oftewel naar het moment waarop de benadeelde tot het maken van die kosten overging. De kosten waar het hier om gaat, kunnen in de periode tussen de schadeveroorzakende gebeurtenis en de uiteindelijke schadevaststelling slechts gaandeweg oplopen; de redelijkheid bepaalt uiteindelijk of zij voor vergoeding in aanmerking komen.

\section{Io Slot: de temporele dimensie van het schade(vergoedings)debat}

IIo. In dit preadvies hebben wij willen laten zien dat het schade(vergoedings)debat een temporele dimensie krijgt, waar men schade als een bewegend verschijnsel ziet. Bij de vaststelling van schade moet men twee situaties met elkaar vergelijken, wat niet goed mogelijk lijkt zonder een 'ijkpunt' in de tijd. Bezien vanuit dat punt moet men soms achteromkijken (welke feiten en omstandigheden hebben zich inmiddels voorgedaan?) en soms ook vooruitzien (welke nadelige ontwikkelingen vallen in de toekomst nog te verwachten?). Soms moet men waken voor wijsheid achteraf, soms moet men gebruikmaken van voortschrijdend inzicht. Een schadebegroting kan in zekere zin steeds als een momentopname worden gezien. Bovendien vindt de vergoeding van de schade telkens achteraf of bij voorbaat plaats; in elk geval nooit ogenblikkelijk.

III. Het tijdstip waarop de rechter uitspraak doet, is in beginsel het beslissende moment voor de schadevaststelling. Dat betekent evenwel niet dat altijd alle feiten en omstandigheden die zich tot het tijdstip van de uitspraak hebben voorgedaan in zijn oordeel moeten worden betrokken. Wanneer men uitgaat van een 'momentschade', zoals bij de waardevermindering van een beschadigde zaak, ligt het voor de hand om de omvang van het nadeel te bepalen naar het tijdstip van de beschadiging. Hooguit de naar dat moment te verwachten latere ontwikkelingen zijn nog van betekenis (ex ante), en niet de daadwerkelijke ontwikkelingen voor zover die op het tijdstip van de uitspraak inmiddels bekend zijn geworden. Soms wordt dit wel gezien als een 'abstracte' wijze van schadebegroting die zou afwijken van de uitgangspunten van het schadevergoedingsrecht. Men zou echter ook kunnen stellen dat juist naar dat tijdstip gemeten sprake is van een volledig vergoeding op basis van naar dat tijdstip concreet vastgestelde schade. Is de constatering dat in een gegeven situatie sprake zou zijn van 'over- of ondercompensatie' niet evenzeer afhankelijk van het moment waarnaar men dit beoordeelt? Soms moet men bij de schadebegroting een stap terug zetten in de tijd en 'wegkijken' van feiten en omstandigheden die pas later zijn opgekomen.

II2. Ten aanzien van voortdurende en toekomstige schade kan men evenzeer met tijdgerelateerde problemen worden geconfronteerd: pas gaandeweg wordt meer duidelijk over het 'schadeverloop', terwijl er ten aanzien van de schade die na de uitspraak van de rechter wordt geleden - althans naar redelijke verwachting - een blik in de toekomst moet worden geworpen. De keten van nadelige (maar ook voordelige) gevolgen die aan de aansprakelijkheidscheppende gebeurtenis kunnen worden toegeschreven ontvouwt zich met het verstrijken van de tijd, wat zowel risico's als kansen voor de bij het schadedebat betrokken partijen met zich kan 
brengen. De verbintenis tot vergoeding van schade kan bij een ex post-benadering immers voortdurend worden beïnvloed door later opkomende feiten en omstandigheden (die bijvoorbeeld aanleiding geven tot een discussie over 'causaliteitsdoorbreking' of voordeelstoerekening). Het verstrijken van tijd kan als zodanig dus meer informatie opleveren ten opzichte van het daadwerkelijke schadeverloop - en daarom een reden vormen om ontwikkelingen af te wachten - maar daarmee dus gaandeweg ook allerlei nieuwe schadevergoedingsrechtelijke vragen doen oproepen. 